\title{
Molecularly Imprinted Polymers (MIPs) in Sensors for Environmental and Biomedical Applications: A Review
}

\author{
Abbas J. Kadhem ${ }^{1}\left(\mathbb{D}\right.$, Guillermina J. Gentile ${ }^{2}$ and Maria M. Fidalgo de Cortalezzi ${ }^{1, *(D)}$ \\ 1 Department of Civil and Environmental Engineering, University of Missouri, E2509 Lafferre Hall, \\ Columbia, MO 65211, USA; ajkqmb@mail.missouri.edu \\ 2 Department of Chemical Engineering, Instituto Tecnológico de Buenos Aires, Lavardén 315, \\ Buenos Aires C1437FBG, Argentina; ggentile@itba.edu.ar \\ * Correspondence: fidalgom@missouri.edu; Tel.: +1-573-884-6777
}

Citation: Kadhem, A.J.; Gentile, G.J.; Fidalgo de Cortalezzi, M.M.

Molecularly Imprinted Polymers (MIPs) in Sensors for Environmental and Biomedical Applications: A Review. Molecules 2021, 26, 6233. https://doi.org/10.3390/ molecules26206233

Academic Editor: Alessandro Poma

Received: 16 August 2021

Accepted: 12 October 2021

Published: 15 October 2021

Publisher's Note: MDPI stays neutral with regard to jurisdictional claims in published maps and institutional affiliations.

Copyright: (c) 2021 by the authors. Licensee MDPI, Basel, Switzerland. This article is an open access article distributed under the terms and conditions of the Creative Commons Attribution (CC BY) license (https:/ / creativecommons.org/licenses/by/ $4.0 /)$.

\begin{abstract}
Molecular imprinted polymers are custom made materials with specific recognition sites for a target molecule. Their specificity and the variety of materials and physical shapes in which they can be fabricated make them ideal components for sensing platforms. Despite their excellent properties, MIP-based sensors have rarely left the academic laboratory environment. This work presents a comprehensive review of recent reports in the environmental and biomedical fields, with a focus on electrochemical and optical signaling mechanisms. The discussion aims to identify knowledge gaps that hinder the translation of MIP-based technology from research laboratories to commercialization.
\end{abstract}

Keywords: molecular imprinted polymers; environmental sensing; biomedical devices

\section{Introduction}

The mechanism for the specific recognition of antibodies and antigens, enzymes and substrates, hormones and receptors inspired the development of synthetic materials that mimic nature's ability to selectively capture chemical species from complex mixtures [1]. Molecularly imprinted materials are tailor-made polymers that present molecular recognition sites for a specific or closely-related target molecule [2]. Prior to polymerization, the target analyte, or template, is combined with a functional monomer to form a precursor structure by covalent [3], semi-covalent [4], or non-covalent [5,6] bonding. Then, they are polymerized in the presence of a crosslinker, along with an initiator in a porogenic solvent. Afterwards, the template is eluted, by extraction with a proper solvent or by chemical cleavage, to create empty recognition cavities in the polymer matrix, whose morphology and functionality are complementary to those of the template molecule $[7,8]$.

The concept of molecular imprinting dates from 1930, but it was not until the description made by Wulff and Sarhan in 1972 [9] that research on molecularly imprinted polymers (MIPs) attracted scientific interest, driven by their promising characteristics: simplicity, robustness, stability, ease of preparation, and high affinity and selectivity towards the target molecule [10-13].

MIPs have been fabricated for solid phase extraction [14-18], chromatographic separation [19-23], catalysis [24-28], drug delivery [29-33], study of the structure and function of proteins [34-38], environmental and biomedical sensing [39-43], water and wastewater treatment [44-48], and membrane-based separations [49-53]. MIP use for purification purposes is the most commercially available application, particularly in analytical chemistry; other uses are still in need of further development [54].

The extensive literature on MIPs for sensing applications comprises a wide variety of fields. The transformative impact of MIP-based sensing for environmental and biomedical application is associated with their potential capacity to detect compounds at trace levels in complex matrices without pretreatment, which would open possibilities for contaminant monitoring in situ, as well as fast clinical analysis at the point of care for improved diagnosis 
and treatment. However, and although there is a genuine market need for such devices, MIP-based technology has remained mostly in the academic field.

This article aims to review advances in imprinted molecular technologies, particularly those applied to sensors in the environmental and biomedical fields. First, the most commonly used polymerization methods, physical forms, and materials are briefly described, followed by a comprehensive review of sensor fabrication reports of electrochemical and optical sensors. Given the simplicity and widespread availability of instruments for the detection of electrical and optical signals, these two mechanisms are the most promising for in situ testing and point of care diagnosis. Selected research is described in more detail for each mode of operation and application, to identify knowledge gaps and hurdles in the transition of the technology from laboratory development to commercial products.

\section{Synthesis}

In the synthesis process, the template molecule is covalently or non-covalently reversibly bonded to the functional monomer, with appropriate binding groups, and then polymerized with an excess of crosslinker [55]. The subsequent removal of the template originates microcavities, which are complementary to the shape, size, and spatially orientated functional groups of the template molecule $[1,10]$. Figure 1 presents a scheme of the imprinting process.

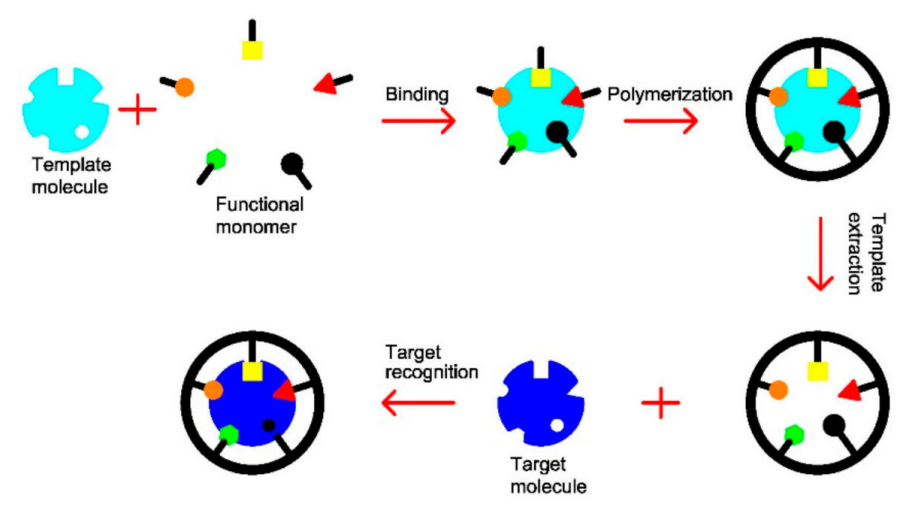

Figure 1. Schematic diagram of the molecularly imprinting process.

The functional monomer confers chemical stability before and during the polymerization and provides the MIP with the ability to interact with the target molecule, while the crosslinker offers mechanical stability and adequate porosity to the polymer, stabilizes the recognition sites, and determines the hydrophobicity [2]. A porogenic solvent brings all components into a homogenous system during the polymerization and creates the pores in the structure [56].

The choice of the functional monomer depends on the chemical structure of the template molecule and on the medium for which the MIP is designed (aqueous or organic). In environmental and biomedical applications, affinity with aqueous solutions is required, limiting the selection to hydrophilic materials. Strong template-monomer interactions enhance the ulterior affinity between the target analyte and the recognition sites. The molecule of the monomer has two units, one for recognition and the other for the polymerization. MIPs constituted by only one monomer have no more than two different kinds of binding interactions, which is sufficient for small molecules [57]. Instead, larger molecules with many functional groups require different specific bonds to achieve a desirable affinity and to prevent non-specific binding; thus, a combination of monomers may be selected: a neutral one as the backbone, along with another that is charged, hydrophobic, or capable of developing hydrogen bonds for constructing the imprinted cavities [58]. Biologically functional molecules that can specifically bind to the template molecule may also be combined with the monomer for enhancing selectivity and affinity; such is the 
case of aptamers, single-stranded oligonucleotides, or peptides with the ability to bind to proteins and nucleic acids [57].

The covalent imprinting route requires the formation of covalent bonds between the functional monomer and the template before polymerization, as well as between the MIP and the target molecule [59]. These bonds should be stable during the polymerization process and be cleaved without harming the MIP. The non-covalent approach, on the other hand, relies principally on hydrogen bonds, but also on hydrophobic, electrostatic, dipole-dipole, and ionic interactions between the functional monomer and the template and between the MIP and the target [60]. The non-covalent method is the most frequently used, due to ease of both preparation and template removal (by a simple wash in acidic or basic aqueous solution or with alcohol), as well as fast rebinding (with the target molecule) kinetics [61]. However, two limitations may arise: first, if the MIP is placed in a polar solvent, the interactions between the template and the functional monomer can be easily disrupted; and second, if the target molecule has only one point of interaction, the recognition properties are limited [59]. These limitations can be partially overcome in the semi-covalent imprinting, in which covalent bonds are formed between the monomer and the template and non-covalent interactions arise between the MIP and the analyte $[4,62]$.

Covalent bonds lead to a sole organization of the functional groups in the cavities, in terms of number and orientation, whereas weaker non-covalent interactions result in less selectivity, since the target may enter the cavity in incorrect orientations, making it necessary to create an excess of binding sites to achieve the required orientation [55]. The template stoichiometrically attaches to the functional monomer in the covalent approach. Instead, the ratio of template to functional monomer usually used is $1: 1$ to $1: 2$ for the semicovalent technique and 1:4 to 1:8 for the non-covalent, according to the affinity between them and the complexity of the template molecule [2].

Conductive polymers can be fabricated by chemical or electrochemical routes from aqueous solutions of their monomers, including enzymatic routes [63]. The imprinted sites are created based on the irreversible overoxidation that the polymers undergo during and after polymerization; the target is expelled from the polymer due to the overoxidation and, therefore, the template extraction procedure and its related complications are avoided [64]. Oxidative-chemical polymerization has been widely used due to its simplicity [63]. It is initiated by an oxidizing compound, such as $\mathrm{FeCl}_{3}$ or $\mathrm{H}_{2} \mathrm{O}_{2}$ [63], and is applied to the synthesis of polypyrrole, polyaniline, polythiophene, poly(1,10-phenanthroline-5,6-dione), poly(pyrrole-2-carboxylic acid), poly-9,10-phenanthrenequinone, polyphenanthroline, and some other conducting polymers. The most important electrochemical method of preparing conducting polymers is the anodic oxidation of suitable monomer species when the polymer formation and oxidation processes occur simultaneously [65]. Electrochemical polymerization has advantages over the chemical methods, as the overoxidation of the polymer creates oxygen containing groups that are useful to promote the recognition/attachment of the MIP target compounds [63]. On the other hand, cathodic electropolymerization has rarely been applied to the synthesis of conducting polymers [65]. Some redox enzymes (oxidases, such as glucose oxidase) and their substrates were used in a process similar to the chemical polymerization, due to their catalytic action that forms hydrogen peroxide. This process is conducted in an aqueous environment at neutral $\mathrm{pH}$ and room temperature, for maximal enzymatic activity, which, in turn, results in high biocompatibility of the polymers as desirable for biosensing applications [63]. Polymer deposition can be achieved by nucleation, growth, and other chemical steps in solid state conditions applying potentiostatic, potentiodynamic, or galvanostatic techniques to start and control these processes [65]. The selection of the deposition technique and the adjustment of the process parameters enable the formation of sensors with different characteristics. The process parameters most commonly adjusted are the applied voltage, potential pulse duration or potential sweep rate (cycling), and the electrical current [63]. 


\subsection{Imprinting Techniques for Sensors}

Ertürk and Mattiasson [66] describe bulk, epitope, and surface imprinting techniques that are especially used in the field of sensors.

Bulk imprinting requires the whole template molecule to be fully imprinted in the polymeric matrix, followed by polymerization and, finally, template removal. Then, the bulk polymer is crushed to obtain smaller particles. This is the preferred option in the case of small templates, since adsorption and release of the molecule are faster and reversible, with the consequent option of support reuse.

Epitope imprinting, on the other hand, relies on a small part of the template molecule being imprinted, making it useful for macromolecules, where only the imprinted fraction is able to represent the whole molecule, and reducing non-specific binding. Rachkov and Minoura [67] employed this concept to covalently bond only a peptide epitope, instead of the whole protein, to a surface, prior to polymerization. Removal of the support surface with the template allowed a thin film to be obtained, which proved effective in capturing the target protein.

Surface imprinting produces recognition sites only on the surface of the substrate by different routes, i.e., soft lithography, template immobilization, grafting, and emulsion polymerization. As the imprinting only takes place on the surface, a lower amount of template molecules is required, but sensitivity decreases because of the reduction in imprinting sites.

Other techniques have been applied less frequently to MIP fabrication, including soft lithography, template immobilization, and grafting.

Soft lithography (stamping) includes a step in which a pre-polymerization layer is coated on a transducer surface and where the template stamp is pressed. The obtained films are complementary to the template in structure, geometry, and chemistry.

Template immobilization is based on a molecule that is fixed onto a solid support by chemical bondings. For example, proteins are adsorbed on a support and are surrounded by the formation of a layer of disaccharides, followed by the formation of a thin plasma film. Dissolution and extraction of the template protein produce cavities on the surface that are complementary to the protein. Grafting first adsorbs the template to a support already grafted with the polymeric functional groups, obtaining affinity for the target.

\subsection{Materials for MIP Fabrication}

MIPs have been reported in a wide variety of functional monomers and crosslinkers, mainly determined by the type of application and target intended, and the initiators given by the polymerization reaction route.

Among the functional monomers, those containing carboxyl groups are preferred for the non-covalent technique, since they can be hydrogen donors and acceptors at the same time and are useful for the formation of hydrogen bonds. For instance, methacrylic acid (MAA) participates in non-covalent imprinting $[54,57,58,60,68-70]$, forming ionic unions with amines and hydrogen bonds with amides, carbamates, and carboxylic groups [69]. Other functional monomers often used in the non-covalent technique include acrylamide (AAM) [54,58,60,70], acrylic acid (AA) [58,60,69], methyl methacrylate [54,69], 4-vinylpyridine [69,70], 2-vinylpyridine [69], and 1-vinylimidazole [69]. Pyrrole [54,68,71] offers good electrical conductivity, biocompatibility, and redox activity [72]. Aniline [54] forms polyaniline, a conducting polymer with a reversible redox system, environmental stability, and easy chemical or electrochemical polymerization [73]. In an extensive work, Chen et al. [61] mentioned the less often employed 2-acrylamido-2-methyl-1propane sulfonic acid, 3-aminopropyltriethoxysilane (APTES), 4-ethylstyrene, glycidoxypropyltrimethoxysilane, 2-hydroxyethyl methacrylate (HEMA), itaconic acid (IA), methacrylamide (MAAM), 3-methylacryloxyprolyl trimethoxysilane, methylvinyldiethoxysilane, styrene, pVinylbenzoic acid, trans-3-(3-pyridyl)-acrylic acid, and trifluoromethyl acrylic acid. Otherwise, $\mathrm{N}$-isopropylacrylamide (NIPAAm) [58,60,74], and o-phenylenediamine (o-PD) [75,76] may also be cited for the non-covalent approach. Vinylferrocene and ferrocenylmethyl methacrylate have been used as electroactive monomers, which allowed for the electrochemical detection 
of non-electroactive targets [77-80]. Fewer monomers can be selected for the semi-covalent or covalent approach, since specific bonds must develop; examples of these functional monomers are tert-butyl p-vinylphenol carbonate, 4-vinyl aniline, 4-vinyl benzaldehyde, and 4-vinyl benzene boric acid for covalent [61], whereas 3-isocyanatopropyltriethoxysilane [61] and maminophenylboronic acid $[60,81]$ have been used for semi-covalent imprinting, although it is also highly dependent on the target molecule's chemistry and interactions.

The two most often used crosslinkers are ethylene glycol dimethacrylate (EGDMA) [8, $54,57,60,61,69]$ and divinylbenzene $[8,60,61,69]$. Both chemicals were applied in the noncovalent approach by means of free radical polymerization. Other compounds commonly reviewed for the same purpose are 3,5-bis(acryloylamido)benzoic acid, N,O-bisacryloyl- $L$ phenylalaninol, $N, O$-bis methacryloyl ethanolamine, pentaerythritol triacrylate, trimethylolpropane trimethacrylate [61,69], 2,6-bisacryloylamidopyridine, 1,4-diacryloyl piperazine, glycidil methacrylate, 1,3-diisopropenyl benzene, $N, N^{\prime}$-methylenediacrylamide, $N, N^{\prime}-1$,4-phenylenediacrylamine, and tetramethylene dimethacrylate [61]. For the freeradical polymerization of covalent complexes, bis-(1-(tert-butylperoxy)-1-methylethyl)benzene, dicumyl peroxide, and triallyl isocyanurate have been mentioned [61]. Also, $N, N^{\prime}$-methylenebisacrylamide (MBA) [8,60,69], N,N-1,4-phenylenediacrylamide, and pentaerythritol tetraacrylate [69] were found as common examples of crosslinkers.

In free radical polymerization, the pre-polymerization monomer-target complex is subjected to heat or ultraviolet (UV) radiation in the presence of an initiator, such as 2,2' azobis(isobutyronitrile) (AIBN) [54,61], 4,4'-azo(4-cyanovaleric acid), or azobis dimethylvaleronitrile [61]. UV light at the maximum absorption wavelength of the compound or high temperature enables the decomposition of the azo compounds and generates free radicals that start the chain reactions. Organic peroxides, e.g., benzoyl peroxide or benzyl dimethyl acetal, initiate the process by redox reactions, heat, or photochemically, and are especially suitable for aqueous matrices, since they are soluble in water as well as in organic solvents. Inorganic oxidants, such as potassium persulfate, have also been reported.

For the detection of organic, relatively hydrophobic pollutants in environmental applications, the porogenic solvent tends to be aprotic and non-polar, e.g., chloroform, toluene, acetonitrile, and tetrahydrofuran [59]. However, biomolecules require other kinds of solvents, since they are usually insoluble or unstable in organics. The polarity of the porogen is a key characteristic for its selection, particularly in non-covalent MIPs, as it affects the interactions between the template and the functional monomer, which, in turn, define the adsorption properties.

\subsection{Physical Form}

MIPs have been reported in different physical forms, such as blocks or monoliths, microspheres, nanospheres, thin films, nanocomposite membranes, and nanowires. Figure 2 shows a schematic illustration of these physical forms.

The choice of the physical form is often dictated by the application, and it defines the polymerization technique to be used [82].

Nano and microspheres have both surface and internal porosity, which results in desirable properties such as high surface area, low density, and a high loading capacity, and may find applications in analytical chemistry and biomedical applications: drug delivery, absorption and desorption, high speed chromatography, and tissue regeneration $[83,84]$.

Different polymerization techniques may produce porous microspheres, such as suspension [85-88], precipitation [89-93], emulsion [94-97], grafting [98,99], and swelling [100-102], as well as a combination of two of these methods $[103,104]$. For example, in swelling polymerization, previously formed beaded seeds made of silica or polymers are used as scaffolds for the polymerization. 


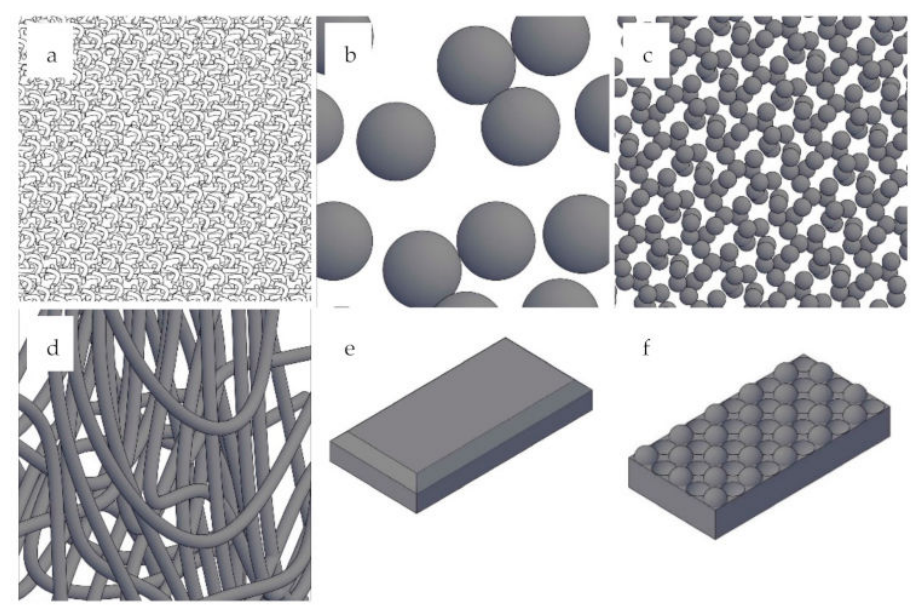

Figure 2. MIP physical forms: (a) blocks or monoliths, (b) microspheres, (c) nanospheres, (d) thin films, (e) nanocomposite membranes, and (f) nanowires.

The suspension polymerization process is useful when both the monomer and the crosslinker are insoluble in the porogen, thus forming two phases, i.e., a liquid matrix that contains droplets of the monomer, inside which polymerization occurs [83]. The obtained spheres usually have a diameter between 10 and $100 \mu \mathrm{m}$ [105]. It is often necessary to include an adequate stabilizer that covers the droplets in the form of a thin film and prevents coalescence, controling the size of the particles [106]. Common stabilizers include surfactants [107] and ionic liquids [108]. Solvents compatible with the stabilizers may be water [109], silicone oil [110], and polyvinyl alcohol [111]. As stated above, water may interfere with the non-covalent bonding between the functional monomer and the template; therefore, its use is limited to those cases where the stability is not affected, while the other solvents mentioned were able to overcome this drawback, but the monodispersivity was negatively affected [112].

In the precipitation or dispersion polymerization process, the components of the MIP are mixed with a much higher amount of solvent than required in the traditional polymerization. The polymer grows at a larger extent and precipitates when the chain is long enough to be insoluble [113]. The obtained particles are smaller, usually between 0.3 and $10 \mu \mathrm{m}$ [114], with more uniform size, and are recovered by simple washing and centrifugation. It is possible to control the size and shape of the particles [115] without the aid of surfactants or stabilizers, which avoids potential contamination of the MIPs. This technique was first developed by Mosbach and collaborators [116] for the synthesis of MIP microspheres [117], nanospheres [118], core-shell particles [119], thin films [120], and nanocomposites [121].

Core-shell MIP particles are obtained by grafting or surface polymerization. All the MIP components are adsorbed on the surface of preformed beads, such as porous silica or spherical polymers, before the polymerization starts. Once the free-radical polymerization is over, the bead is removed, thus obtaining a spherical particle coated by a thin layer of MIP. It is important to limit the free-radical polymerization to the bead surface, for example, with the inclusion of an immobilized chemical compound whose functions are to initiate, transfer, and terminate the polymerization (iniferters) [122,123]. Advantages of the technique are a high surface density of polymer chains, high stability of the coated layer, and the ability to graft different polymers to the same substrate [124,125].

Emulsion polymerization can lead to both spherical and core-shell particles. The monomers are immersed in a solvent, usually water, in which they do not dissolve, and emulsification takes place. Then, the polymerization is started by an initiator soluble in one phase. When the process is finished, a fluid of milky consistency is obtained, which is usually referred as latex, synthetic latex, or polymer dispersion. In contrast with suspension polymerization, the droplets are inside micelles stabilized with the aid of a surfactant. To prepare core-shell particles, the core particles are produced and afterwards the shell layer 
is generated by emulsion polymerization. The type and amount of surfactant controls the particle size, usually in the range of $10-1000 \mathrm{~nm}[126,127]$. The main disadvantage of this method is the use of water and surfactants that may precipitate interferences during polymerization between the template and the functional monomer, particularly in the non-covalent approach.

Block or monolith MIPs are obtained by bulk polymerization, also known as the traditional method. Bulk polymerization is the simplest and most widely used method, since the equipment is not sophisticated and no particular knowledge or mastery of organic chemistry is needed. The main components (template, functional, and crosslinking monomers) are mixed along with the initiator in a low volume of porogenic solvent, and the polymerization starts by heat or UV radiation. When the process is concluded, the monoliths are crushed, ground, and sieved to the desired particle size, reaching the micrometer range. Evident disadvantages of the grinding are that the obtained material is irregular in shape and size, nanosized particles cannot be produced, and many recognition sites are broken or inaccessible due to the lack of internal porosity.

In the field of analytical chemistry, Matsui et al. [128,129] introduced the monolithic imprinted polymerization technique that enables monolithic imprinted columns to be obtained for HPLC by a simple, one-step, free radical polymerization process that takes place within a chromatographic column. The template, functional monomer, cross-linking monomer, and initiator are first dissolved in the porogen and then the mixture is poured into the column. After the polymerization takes place, the template and the solvent are washed out of the column. An advantage of this route compared to traditional polymerization is that it is not necessary to crush, grind, sift, and pack the final material. Other advantages reported by the author are ease of preparation, good reproducibility, selectivity, sensitivity, high porosity, permeability, surface area, and fast mass transport.

\section{Environmental and Biomedical Applications of MIPs}

The specific binding properties of MIPs make them ideal materials for sensor fabrication. Although the literature on polymer formulation and synthesis methods is extensive, reports of effective use of MIPs on specific applications are scarce. Moreover, in order to use a MIP as a sensor, it needs to be coupled with a transducer or reading mechanism capable of determining the amount of target rebinding to the MIP after exposure to the test sample. The transducer technique should be simple, reliable, and not require external instruments or supplies. Based on these characteristics and their user-friendliness, this review focuses on electrochemical and optical sensors.

A shared objective of MIP-based sensors is to provide the market with simple, fast, and inexpensive methodologies for the detection and quantification of a chemical compound. Besides, researchers have focused their efforts on avoiding sample pretreatments, which are often time-consuming, tedious, or expensive, and in many cases involve toxic or hazardous solvents. Current protocols typically include a first pretreatment step, where the target of interest is removed from a complex matrix (e.g., by liquid extraction), followed by separation (e.g., by gas or liquid chromatography), enrichment, and detection.

A comprehensive review of environmental and biomedical sensors is presented below, organized by the sensing mechanism: electrochemical or optical. The limit of detection (LOD) and the limit of quantification (LOQ) are presented for each work, when reported by the authors and calculated as three and ten times the standard deviation, respectively, of the blank measured with the standards divided by the slope of calibration curve, as suggested by MacDougall et al. [130]. The units given by the authors were reproduced in this work to provide understandable and useful information, according to the specific target. Target molecules and the matrix in which they were tested are also listed for each work. Although all the cited reports focus on environmental or biomedical applications, not all of them employ a testing matrix that mimics real natural environments or the actual subjects of study (humans or animals). The advances and discoveries in the field are impressive and promising for the technology to transfer outside of research laboratories to commercial 
products. Yet, some shortcomings that need to be addressed are: limited detection, slow response, high LODs and LOQs, interferences, impaired performance in real complex mixtures, and reusability of the adsorbent to reduce waste, as well as devising, conceiving, and putting to work platforms to manufacture ready-to-use devices.

\subsection{Electrochemical Sensors in Environmental and Biomedical Applications}

Electrochemical sensors include a cell with a working electrode of particular interest, accompanied by a reference and an auxiliary electrode. Depending on the measured electrical parameter, they can be classified into three categories: conductivity or capacitance sensors, potentiometric sensors, and voltammetric or amperometric sensors [131,132]. Conductivity or capacitance sensors measure the change in conductivity or the capacitive impedance over time as a function of the concentration of the target. Potentiometric sensors measure the potential of a redox reaction in order to determine a concentration, and voltammetric sensors measure the effect of the concentration of the target on the current-potential of the redox reaction. Among these last, the amperometric sensors are a subcategory that measure the current that results from a fixed potential that is applied to a redox system and is related to the concentration of the participating species.

Table 1 summarizes recent reports of MIP-based electrochemical sensors, grouped by quantifiable electrical output generated upon the rebinding of the target molecule.

Table 1. MIP-based electrochemical sensors in environmental and biomedical applications.

\begin{tabular}{|c|c|c|c|c|c|c|}
\hline \multirow{2}{*}{ Sensor } & \multirow{2}{*}{ Functional Monomer } & \multirow{2}{*}{ Electrode } & \multirow{2}{*}{ Target } & \multirow{2}{*}{ Sample } & Linear Range & \multirow{2}{*}{ Ref. } \\
\hline & & & & & LOD & \\
\hline \multicolumn{7}{|c|}{ Capacitance } \\
\hline Aptamer-MIP & Dopamine & $\mathrm{Au}$ & $\begin{array}{c}\text { Prostate specific } \\
\text { antigen }\end{array}$ & TBST buffer & $\begin{array}{l}0.1-100 \mathrm{ng} / \mathrm{mL} \\
1 \mathrm{pg} / \mathrm{mL}\end{array}$ & [133] \\
\hline Sol-gel-MIP & $\begin{array}{l}N, N \text {-methylene bis } \\
\text { acrylamide (MBAA) }\end{array}$ & $\mathrm{C}$ & Methidathion & Wastewater & $\begin{array}{c}40-200 \mu \mathrm{g} / \mathrm{L} \\
5.14 \mu \mathrm{g} / \mathrm{L}\end{array}$ & [134] \\
\hline $\begin{array}{l}\text { Silica NP-Au } \\
\text { NP-MIP-Chitosan }\end{array}$ & MAA & GCE & Fumosin $B_{1}$ & Maize, milk & $\begin{array}{c}0.001-100 \mathrm{ng} / \mathrm{mL} \\
0.35 \mathrm{pg} / \mathrm{mL}\end{array}$ & [135] \\
\hline MIP & MAA & $\mathrm{Au}$ & $\begin{array}{l}\mathrm{N}- \\
\text { formylamphetamine }\end{array}$ & Ultrapure water & $\begin{array}{l}\text { Variable } \\
10 \mu \mathrm{M}\end{array}$ & [136] \\
\hline MIP & MAA & $\mathrm{Au}$ & Metergoline & PBS & $\begin{array}{c}1-50 \mu \mathrm{M} \\
1 \mu \mathrm{M}\end{array}$ & [137] \\
\hline MIP & $\begin{array}{l}N \text {-allylthiourea } \\
\text { (thiourea) }\end{array}$ & $\mathrm{Pt}$ & Phosphate & Wastewater & $\begin{array}{c}0.66-8 \mathrm{mg} \mathrm{P} / \mathrm{L} \\
0.16 \mathrm{mg} \mathrm{P} / \mathrm{L}\end{array}$ & [138] \\
\hline MIP & o-aminophenol & GCE & Norepinephrine & $\begin{array}{l}\text { Human plasma and urine, } \\
\text { pharmaceuticals }\end{array}$ & $\begin{array}{c}5 \times 10^{-8}-10^{-5} \mathrm{M} \\
4.9 \times 10^{-10} \mathrm{M}\end{array}$ & [139] \\
\hline MIP & Pyrrole & PGE & Chlorpyrifos & $\begin{array}{c}\text { Tap water, non-agricultural } \\
\text { soil, corn leaves }\end{array}$ & $\begin{array}{c}20-300 \mu \mathrm{g} / \mathrm{L} \\
4.5 \mu \mathrm{g} / \mathrm{L}\end{array}$ & [140] \\
\hline MIP & Pyrrole & $\begin{array}{l}\text { B-doped nanocrystalline } \\
\text { diamond }\end{array}$ & Theophylline & PBS & $\begin{array}{l}\text { NI } \\
\text { NI }\end{array}$ & [141] \\
\hline \multicolumn{7}{|c|}{ Potentiometry } \\
\hline MIP & MAA & PVC & Propranolol & Water, pharmaceuticals & $\begin{array}{c}10^{-4}-10^{-1} / 10^{-5}-10^{-1} \\
\mathrm{M}^{*} \\
10^{-4} / 10^{-5} \mathrm{M}^{*}\end{array}$ & [142] \\
\hline $\begin{array}{c}\text { MIP- } \\
\text { Nanographene-IL }\end{array}$ & MAA & $\mathrm{CPE}$ & Losartan & Urine, pharmaceuticals & $\begin{array}{c}3 \times 10^{-9}-10^{-2} \mathrm{M} \\
1.82 \times 10^{-9} \mathrm{M}\end{array}$ & [143] \\
\hline MIP NP & MAA & PVC & Histamine & Wine, fish & $\begin{array}{c}1.12 \times 10^{-6}-10^{-2} \mathrm{M} \\
1.12 \times 10^{-6} \mathrm{M}\end{array}$ & [144] \\
\hline MIP-MWCNT & MAA & $\mathrm{Cu}$ & Lindane & $\begin{array}{l}\text { Ground, tap, and sea water, } \\
\text { orange, grape, tomato, } \\
\text { cabbage }\end{array}$ & $\begin{array}{c}10^{-9}-10^{-5} ; 10^{-5}-10^{-3} \\
\mathrm{M} \\
10^{-10} \mathrm{M}\end{array}$ & [145] \\
\hline MIP & MAA & PVC & $\begin{array}{l}\text { Imidocarb } \\
\text { dipropionate }\end{array}$ & Bovine liver and kidney & $\begin{array}{c}10^{-5}-10^{-2} \mathrm{M} \\
2 \times 10^{-6} \mathrm{M}\end{array}$ & [146] \\
\hline MIP & MAA & GCE & Heparine & Heparine sodium injection & $\begin{array}{c}3 \times 10^{-9}-7 \times 10^{-7} \mathrm{M} \\
10^{-9} \mathrm{M}\end{array}$ & [147] \\
\hline MIP & $4-\mathrm{VP}$ & PVC & Bisphenol A & $\begin{array}{l}\text { Polycarbonate drinking } \\
\text { water bottle in water }\end{array}$ & $\begin{array}{c}0.1-1 \mu \mathrm{M} \\
0.02 \mu \mathrm{M}\end{array}$ & [148] \\
\hline $\begin{array}{l}\text { Nanostructured } \\
\text { MIP particles }\end{array}$ & MAA & $\begin{array}{l}\text { GCE } \\
\text { CPE }\end{array}$ & Captopril & $\begin{array}{c}\text { solution } \\
\text { Captopril tablet }\end{array}$ & $\begin{array}{c}10^{-6}-10^{-1} \mathrm{M}(\mathrm{GCE}) ; 3 \\
\times 10^{-9}-10^{-1} \mathrm{M}(\mathrm{CPE}) \\
\mathrm{NI}(\mathrm{GCE}) ; 10^{-9} \mathrm{M} \\
(\mathrm{CPE})\end{array}$ & [149] \\
\hline
\end{tabular}


Table 1. Cont.

\begin{tabular}{|c|c|c|c|c|c|c|}
\hline \multirow{2}{*}{ Sensor } & \multirow{2}{*}{ Functional Monomer } & \multirow{2}{*}{ Electrode } & \multirow{2}{*}{ Target } & \multirow{2}{*}{ Sample } & Linear Range & \multirow{2}{*}{ Ref. } \\
\hline & & & & & LOD & \\
\hline \multicolumn{7}{|c|}{ Voltammetry } \\
\hline MIP & Pyrrole & GCE & $\begin{array}{l}\text { Triacetone } \\
\text { triperoxide }\end{array}$ & Acetonitrile & $\begin{array}{c}82-44,300 \mu \mathrm{g} / \mathrm{L} \\
26.9 \mu \mathrm{g} / \mathrm{L}\end{array}$ & [150] \\
\hline MIP-C NT/IL & Pyrrole & GCE & Melamine & Milk & $\begin{array}{c}0.4-9.2 \mu \mathrm{M} \\
0.11 \mu \mathrm{M}\end{array}$ & [151] \\
\hline MIP-RGO-Au NP & MAA & GCE & Carbofuran & Vegetables & $\begin{array}{c}5 \times 10^{-8}-2 \times 10^{-5} \mathrm{M} \\
2 \times 10^{-8} \mathrm{M}\end{array}$ & [152] \\
\hline MIP-MWCNT-IL-Pt & 4-vinylpyridine & GCE & Tartrazine & $\begin{array}{l}\text { Orange powder and soft } \\
\text { drinks }\end{array}$ & $\begin{array}{c}0.03-5 ; 5-20 \mu \mathrm{M} \\
8 \mathrm{nM}\end{array}$ & [153] \\
\hline MIP-MWCNT & Pyrrole & GCE & Ochratoxin A & Beer, wine & $\begin{array}{c}5 \times 10^{-8}-10^{-6} \mathrm{M} \\
4.1 \times 10^{-9} \mathrm{M}\end{array}$ & [154] \\
\hline MIP-MWCNT & Pyrrole & PGE & Triamterene & $\begin{array}{l}\text { Human serum, } \\
\text { pharmaceuticals }\end{array}$ & $\begin{array}{c}0.08-265 \mu \mathrm{M} \\
3.35 \mathrm{nM}\end{array}$ & [155] \\
\hline Sol-gel-MIP & $\begin{array}{l}\text { Antimony-doped tin } \\
\text { oxide (ATO) }\end{array}$ & $\mathrm{Pt}$ & $\beta_{2}$-agonists & Human serum & $\begin{array}{c}5.5 \mathrm{nM}-6.3 \mu \mathrm{M} \\
1.7 \mathrm{nM}\end{array}$ & [156] \\
\hline MIP-MWCNT & 2,2'-dithiodianiline & GCE & Valganciclovir & Human serum, tablet & $\begin{array}{c}1-500 ; 500-2000 \mathrm{nM} \\
0.3 \mathrm{nM}\end{array}$ & [157] \\
\hline MIP & $o$-aminophenol & $\mathrm{Au}-\mathrm{Ag}$ & Dopamine & $\begin{array}{l}\text { Rabbit serum, rat brain } \\
\text { tissue }\end{array}$ & $\begin{array}{c}2 \times 10^{-13}-2 \times 10^{-8} \mathrm{M} \\
7.63 \times 10^{-14} \mathrm{M} \\
2 \times 10^{-9}-2.5 \times 10^{-7}\end{array}$ & [158] \\
\hline Au NP-MIP & $\begin{array}{l}\text { Au NPs@IL, ionic } \\
\text { liquid (IL, i.e., } \\
\text { 3-propyl-1- } \\
\text { vinylimidazolium } \\
\text { bromide) }\end{array}$ & GCE & Dimetridazole & Milk, honey & $\begin{array}{c}2.5 \times 10^{-7}-3 \times 10^{-6} \\
\mathrm{M} \\
5 \times 10^{-10} \mathrm{M}\end{array}$ & [159] \\
\hline MIP-GO & APTES & GCE & Bisphenol A & Milk, mineralized water & $\begin{array}{c}0.006-0.1 ; 0.2-20 \mu \mathrm{M} \\
0.003 \mu \mathrm{M}\end{array}$ & [160] \\
\hline MIP-MWCNT & Pyrrole & GCE & Norfloxacin & Human urine & $\begin{array}{c}10^{-7}-8 \times 10^{-6} \mathrm{M} \\
4.6 \times 10^{-8} \mathrm{M}\end{array}$ & [161] \\
\hline MIP & Pyrrole & BDD & Sulfamethoxazole & Surface water & $\begin{array}{l}0.1-100 \mu \mathrm{M} \\
24.1 \mathrm{nM}\end{array}$ & [162] \\
\hline MIP-Melamine & Melamine & EPPG & $\begin{array}{l}\text { 8- } \\
\text { hydroxydeoxyguanosine }\end{array}$ & Human urine & $\begin{array}{c}2 \times 10^{-8}-3 \times 10^{-6} \mathrm{M} \\
3 \times 10^{-9} \mathrm{M}\end{array}$ & [163] \\
\hline $\begin{array}{l}\text { MIP-Chitosan-C } \\
\text { dots }\end{array}$ & $\begin{array}{l}\text { 3- } \\
\text { aminobenzeneboronic } \\
\text { acid }\end{array}$ & GCE & Glucose & Human serum & $\begin{array}{c}0.5-40 ; 50-600 \mu \mathrm{M} \\
0.09 \mu \mathrm{M}\end{array}$ & [43] \\
\hline MIP & $\begin{array}{c}\text { 2-vinylpyridine, } \\
\text { methacrylic acid, and } \\
\text { acrylamide }\end{array}$ & CPE & Hexazinone & River water & $\begin{array}{c}1.19 \times 10^{-11}-1.1 \times \\
10^{-9} \mathrm{M} \\
2.6 \times 10^{-12} \mathrm{M}\end{array}$ & [164] \\
\hline MIP-Au-Polyaniline & MAA & GCE & Melamine & Milk, food & $\begin{array}{c}10^{-5}-10 \mu \mathrm{M} \\
1.39 \times 10^{-6} \mu \mathrm{M}\end{array}$ & [165] \\
\hline MIP-GO-Ag NP & Pyrrole & C & Bisphenol A & $\begin{array}{l}\text { PVC and soil in water } \\
\text { solution }\end{array}$ & $\begin{array}{c}10^{-11}-10^{-8} \mathrm{M} \\
3.2 \times 10^{-12} \mathrm{M} \\
10^{-10}-7 \times 10^{-9} ; 7 \times\end{array}$ & [166] \\
\hline MIP & MAA & CPE & Histamine & Human serum & $\begin{array}{c}10^{-9}-4 \times 10^{-7} \mathrm{M} \\
7.4 \times 10^{-11} \mathrm{M}\end{array}$ & [167] \\
\hline MIP-Algae & $\begin{array}{l}N \text {-methacryloyl } \\
\text { glutamic acid }\end{array}$ & C & $\mathrm{Cu}(\mathrm{II})$ & $\begin{array}{l}\text { Human serum, soil, lake } \\
\text { water, pharmaceutical } \\
\text { tablet }\end{array}$ & $\begin{array}{l}\text { Depending on the } \\
\text { sample }\end{array}$ & [168] \\
\hline MIP-MWNT-Au NP & $\begin{array}{l}P \text {-aminothiophenol } \\
(\mathrm{p}-\mathrm{ATP})\end{array}$ & GCE & Cholesterol & Ethanol & $\begin{array}{l}10^{-13}-10^{-9} \mathrm{M} \\
3.3 \times 10^{-14} \mathrm{M}\end{array}$ & [39] \\
\hline $\begin{array}{l}\text { MIP-Chitosan- } \\
\text { Acetylene } \\
\text { black }\end{array}$ & Chitosan & GCE & Bisphenol A & Drinking water & $\begin{array}{c}0.005-0.2 ; 0.5-10 \mathrm{mM} \\
2 \mathrm{nM}\end{array}$ & [169] \\
\hline $\begin{array}{l}\text { MIP-Chitosan- } \\
\text { Graphene }\end{array}$ & Chitosan (CHI) & ABPE & Bisphenol A & $\begin{array}{l}\text { Bottled water, canned } \\
\text { beverages }\end{array}$ & $\begin{array}{c}0.008-1 ; 1-20 \mu \mathrm{M} \\
0.006 \mu \mathrm{M}\end{array}$ & [170] \\
\hline MIP & $\begin{array}{l}\text { 2-aminothiophenol } \\
\text { (2-ATP) }\end{array}$ & $\mathrm{Au}$ & $\begin{array}{l}\text { Sodium lauryl } \\
\text { sulfate }\end{array}$ & $\begin{array}{l}\text { River and wastewater, } \\
\text { personal hygiene products }\end{array}$ & $\begin{array}{c}0.1-1000 \mathrm{pg} / \mathrm{mL} \\
0.18 \mathrm{pg} / \mathrm{mL}\end{array}$ & [171] \\
\hline MIP & MAA & СРE & Methyl parathion & Soil, vegetables & $\begin{array}{c}10^{-12}-8 \times 10^{-9} \mathrm{M} \\
3.4 \times 10^{-13} \mathrm{M}\end{array}$ & [172] \\
\hline MIP & $\begin{array}{l}\text { o-phenylenediamine } \\
(\mathrm{o}-\mathrm{PD})\end{array}$ & $\mathrm{Au}$ & Atrazine & Deionized water & $\begin{array}{c}5 \times 10^{-9}-1.4 \times 10^{-7} \\
\mathrm{M} \\
10^{-9} \mathrm{M}\end{array}$ & [76] \\
\hline MIP-Cu-Melamine & Melamine & GCE & Metronidazole & Standard injection & $\begin{array}{l}0.5-1000 \mu \mathrm{M} \\
0.12 \mu \mathrm{M}\end{array}$ & [173] \\
\hline MIP-Graphene & Pyrrole & C & $\underset{\text { A }}{\text { Tetrabromobisphenol }}$ & Rain and lake water & $\begin{array}{c}0.5-4.5 \mathrm{nM} \\
0.23 \mathrm{nM}\end{array}$ & [174] \\
\hline $\begin{array}{c}\mathrm{Ni} \\
\text { NP-MIP-Graphene }\end{array}$ & Pyrrole & C & $\begin{array}{l}\text { Tetrabromobisphenol } \\
\text { A }\end{array}$ & Rain, lake, and tap water & $\begin{array}{l}0.5-10^{4} \mathrm{nM} \\
0.13 \mathrm{nM}\end{array}$ & [175] \\
\hline $\begin{array}{l}\text { MIP-Graphene-C } \\
\text { NT }\end{array}$ & Pyrrole & C & $\begin{array}{l}\text { Tetrabromobisphenol } \\
\text { A }\end{array}$ & Fish & $\begin{array}{l}10^{-11}-10^{-8} \mathrm{M} \\
3.7 \times 10^{-12} \mathrm{M}\end{array}$ & [176] \\
\hline Ag-N-RGO-MIP & $\begin{array}{l}o \text {-phenylenediamine } \\
(o-P D)\end{array}$ & GCE & Salbutamol & Human urine, pork & $\begin{array}{c}0.03-20 \mu \mathrm{M} \\
7 \mathrm{nM}\end{array}$ & [177] \\
\hline Magnetite NP-MIP & MAA & mGEC & Methyl parathion & Fish & $\begin{array}{c}\mathrm{NI} \\
1.22 \times 10^{-6} \mathrm{mg} / \mathrm{L}\end{array}$ & [178] \\
\hline MIP-MWNT & $\begin{array}{l}\text { MAA and } \\
\text { vinylpyridine }\end{array}$ & GCE & Bisphenol A & Baby feeding bottle in PBS & $\begin{array}{c}0.1 \mathrm{nM}-400 \mu \mathrm{M} \\
0.02 \mathrm{nM}\end{array}$ & [179] \\
\hline
\end{tabular}


Table 1. Cont.

\begin{tabular}{|c|c|c|c|c|c|c|}
\hline \multirow[t]{2}{*}{ Sensor } & \multirow[t]{2}{*}{ Functional Monomer } & \multirow[t]{2}{*}{ Electrode } & \multirow[t]{2}{*}{ Target } & \multirow[t]{2}{*}{ Sample } & Linear Range & \multirow[t]{2}{*}{ Ref. } \\
\hline & & & & & LOD & \\
\hline MIP-Ag NP & Pyrrole & PGE & Mebeverine & Human serum, capsule & $\begin{array}{c}10^{-8}-10^{-6} ; 10^{-5}-10^{-3} \\
\mathrm{M} \\
8.6 \times 10^{-9} \mathrm{M}\end{array}$ & [180] \\
\hline MIP-Graphene QD & Pyrrole & GCE & Bisphenol A & Tap and sea water & $\begin{array}{c}0.1-50 \mu \mathrm{M} \\
0.04 \mu \mathrm{M}\end{array}$ & [181] \\
\hline MIP & $\begin{array}{l}\text { Amine terminated } \\
\text { poly(N- } \\
\text { isopropylacrylamide) } \\
\text { (PNIPAAm) and } \\
o \text {-phenylenediamine } \\
(o-P D)\end{array}$ & $\mathrm{Au}$ & Folic acid & What tongoring iujco & $\begin{array}{c}1-200 \mu \mathrm{M} \\
0.9 \mu \mathrm{M}\end{array}$ & [182] \\
\hline Au NP-MIP & $\begin{array}{l}\text { Acetate buffer (pH } \\
\text { 6.0), quercetin, } \\
\text { resorcinol, methyl } \\
\text { parathion, } \\
\mathrm{KClO}_{4}\end{array}$ & GCE & Methyl parathion & $\begin{array}{l}\text { Water, tangerine juice, } \\
\text { sweet potato leaves }\end{array}$ & $\begin{array}{c}0.05-15 \mu \mathrm{M} \\
0.01 \mu \mathrm{M}\end{array}$ & [40] \\
\hline MIP-MWCNT & 4-vinylpyridine & CPE & Bisphenol A & River, tap, and pure water & $\begin{array}{l}0.08-100 \mu \mathrm{M} \\
0.022 \mu \mathrm{M}\end{array}$ & [183] \\
\hline MIP & Aniline & PGE & L-ascorbic acid & Bovine serum, water & $\begin{array}{c}1-100 \mu \mathrm{M} \\
1 \mu \mathrm{M}\end{array}$ & [184] \\
\hline MIP-Chitosan & Chitosan & $\mathrm{ABPE}$ & Bisphenol A & $\begin{array}{c}\text { Polycarbonate baby } \\
\text { feeding and water bottle, } \\
\text { PVC bottle, PVC food } \\
\text { package in water solution }\end{array}$ & $\begin{array}{l}80 \mathrm{nM}-10 \mu \mathrm{M} \\
\quad 60 \mathrm{nM}\end{array}$ & [185] \\
\hline $\begin{array}{l}\text { MWCNT- } \\
\text { Polyethyleneimine- } \\
\text { MIP }\end{array}$ & Acrylamide & GCE & 2,4-dinitrotoluene & River and wastewater & $\begin{array}{c}2.2 \times 10^{-9}-10^{-6} \mathrm{M} \\
10^{-9} \mathrm{M}\end{array}$ & [186] \\
\hline MIP-RGO-TiO 2 & $\begin{array}{l}\text { Carboxymethyl- } \beta- \\
\text { cyclodextrin } \\
(\mathrm{CM}-\beta-\mathrm{CD})\end{array}$ & $\mathrm{Pt}$ & Toltrazuril & Chicken muscles, egg & $\begin{array}{l}0.43-42.54 \mu \mathrm{g} / \mathrm{L} \\
0.21 \mu \mathrm{g} / \mathrm{L}\end{array}$ & [187] \\
\hline MIP-RGO & Acrylamide & PGE & D-, L-serine & $\begin{array}{l}\text { Blood serum, cerebrospinal } \\
\text { fluid, water, pharmaceutics }\end{array}$ & $\begin{array}{l}\text { Depending on the } \\
\text { sample } \\
0.24 \mathrm{ng} / \mathrm{mL}\end{array}$ & [188] \\
\hline MIP-BN QD & Pyrrole & GCE & Cardiac Troponin-I & Human plasma & $\begin{array}{l}0.01-5 \mathrm{ng} / \mathrm{mL} \\
0.0005 \mathrm{ng} / \mathrm{mL}\end{array}$ & [189] \\
\hline $\begin{array}{c}\text { Conductive } \\
\mathrm{NH}_{2} \text {-MWCNT- } \\
\mathrm{MoS}_{2} \text {-MIP }\end{array}$ & $p$-aminobenzoic acid & GCE & Sulfamerazine & Pork, chicken & $\begin{array}{c}3 \times 10^{-7}-2 \times 10^{-4} \mathrm{M} \\
1.1 \times 10^{-7} \mathrm{M}\end{array}$ & [190] \\
\hline Nano MIP-MWCNT & MAA & GCE & $\begin{array}{l}\text { Trinitroperhydro- } \\
\text { 1,3,5-triazine }\end{array}$ & Tap, river, and sea water & $\begin{array}{c}0.1-10 \mathrm{nM} ; 0.01-1 \mu \mathrm{M} \\
20 \mathrm{pM}\end{array}$ & [191] \\
\hline MIP & $\begin{array}{l}o \text {-Phenylenediamine } \\
(o-P D)\end{array}$ & GCE & 3-methylindole & Tap and lake water & $\begin{array}{c}0.01-1.2 \mu \mathrm{M} \\
4 \mathrm{nM}\end{array}$ & [192] \\
\hline $\begin{array}{l}\text { MIP-Polydopamine- } \\
\text { RGO }\end{array}$ & $\begin{array}{l}o \text {-phenylenediamine } \\
(\mathrm{o}-\mathrm{PD})\end{array}$ & GCE & 2,4-dichlorophenol & Lake water & $\begin{array}{c}2-10 ; 10-100 \mathrm{nM} \\
0.8 \mathrm{nM}\end{array}$ & [193] \\
\hline MIP-ZnO & Pyrrole & ITO/PET & Epinephrine & $\begin{array}{l}\text { Epinephrine hydrochloride } \\
\text { injections }\end{array}$ & $\begin{array}{c}1-10 ; 10-800 \mu \mathrm{M} \\
1 \mu \mathrm{M}\end{array}$ & [194] \\
\hline MIP & $\begin{array}{l}\text { 3-thiophene acetic } \\
\text { acid (3-TAA) }\end{array}$ & $\mathrm{Au}$ & Melphalan & Pharmaceutical tablet & $\begin{array}{c}0.01-0.07 \mathrm{mM} \\
\mathrm{NI}\end{array}$ & [195] \\
\hline MIP & $\begin{array}{l}\text { Vinylferrocene, } \\
\text { 4-vinylpyridine }\end{array}$ & СРE & Benzo(a)pyrene & Ultrapure water & $\begin{array}{c}0-8 ; 2-16 \mu \mathrm{M} \\
0.93 \mu \mathrm{M}\end{array}$ & [78] \\
\hline MIP & $\begin{array}{l}\text { Ferrocenylmethyl } \\
\text { methacrylate }\end{array}$ & C SPE & Bisphenol A & PBS & $\begin{array}{l}4.7-8 \mathrm{nM} \\
3.2 \mathrm{nM}\end{array}$ & [79] \\
\hline MIP microbeads & $\begin{array}{l}\text { Ferrocenylmethyl } \\
\text { methacrylate }\end{array}$ & СРE & Bisphenol A & Ultrapure water & $\begin{array}{l}\mathrm{NI} \\
\mathrm{NI}\end{array}$ & [80] \\
\hline \multicolumn{7}{|c|}{ Capacitance. Voltammetry } \\
\hline MIP & Aminophenol (AP) & $\mathrm{Au}$ SPE & Myoglobin & Synthetic human serum & $\begin{array}{c}1.5-4 \text { (EIS); } 0.8-3.5 \\
\text { (SWV) } \mu \mathrm{g} / \mathrm{mL} \\
1.5 \text { (EIS); } 0.8 \text { (SWV) }\end{array}$ & [196] \\
\hline MIP & $\begin{array}{l}\text { Eriochrome black T } \\
\text { (EBT) }\end{array}$ & $\begin{array}{l}\text { Graphene SPE } \\
\text { C SPE }\end{array}$ & Chloramphenicol & Acetonitrile buffer & $\begin{array}{c}\mu \mathrm{g} / \mathrm{mL} \\
1 \mathrm{nM}-10 \mathrm{mM} \\
0.62 \mathrm{nM}\end{array}$ & [197] \\
\hline \multicolumn{7}{|c|}{ Amperometry } \\
\hline $\begin{array}{l}\text { MIP-MWCNT- } \\
\text { Nafion }\end{array}$ & APTES and PTMS & GCE & 2-nonylphenol & Tap and river water, soil & $\begin{array}{c}0.2-360 \mu \mathrm{M} \\
0.06 \mu \mathrm{M}\end{array}$ & [42] \\
\hline Au NP-MIP & $\begin{array}{l}\text { Functionalized } \\
\text { AuNPs (F-AuNPs) }\end{array}$ & $\mathrm{Au}$ & Dopamine & Human serum & $\begin{array}{l}0.02-0.54 \mu \mathrm{M} \\
\quad 7.8 \mathrm{nM}\end{array}$ & [198] \\
\hline MIP & $\begin{array}{l}\text { O-phenylenediamine- } \\
\text { resorcinol }\end{array}$ & GCE & Tamoxifen & Acetate buffer & $\begin{array}{l}1-100 \mathrm{nM} \\
\mathrm{NI}\end{array}$ & [199] \\
\hline MIP & Acrylamide & $\mathrm{Au}$ & Norfloxacin & Human urine & $\begin{array}{c}10^{-9}-10^{-3} \mathrm{M} \\
10^{-10} \mathrm{M}\end{array}$ & [200] \\
\hline
\end{tabular}


Table 1. Cont.

\begin{tabular}{|c|c|c|c|c|c|c|}
\hline \multirow{2}{*}{ Sensor } & \multirow{2}{*}{ Functional Monomer } & \multirow{2}{*}{ Electrode } & \multirow[t]{2}{*}{ Target } & \multirow[t]{2}{*}{ Sample } & Linear Range & \multirow{2}{*}{ Ref. } \\
\hline & & & & & LOD & \\
\hline \multicolumn{7}{|c|}{ Amperometry } \\
\hline Conducting MIP & $\begin{array}{c}N \text {-phenylethylene } \\
\text { diamine } \\
\text { methacrylamide }\end{array}$ & $\mathrm{Au}$ & $17 \beta$-estradiol & Ethanol/PBS solutions & $\begin{array}{c}10^{-7}-8 \times 10^{-7} \mathrm{M} \\
6.89 \times 10^{-7} \mathrm{M}\end{array}$ & [201] \\
\hline MIP-Pt & $\begin{array}{c}\text { (NPEDMA) } \\
\text { MAA }\end{array}$ & $\mathrm{Ti}$ & Tetracycline & Ultrapure water & $\begin{array}{l}0.1-10 \mathrm{mg} / \mathrm{L} \\
0.026 \mathrm{mg} / \mathrm{L}\end{array}$ & [202] \\
\hline MIP NP & $\begin{array}{l}\text { Vinylferrocene, } \\
\text { ferrocenylmethyl } \\
\text { methacrylate }\end{array}$ & GCE & Vancomycin & TRIS buffer & $\begin{array}{c}83-410 \mu \mathrm{M} \\
\mathrm{NI}\end{array}$ & [77] \\
\hline MIP & Pyrrole & Pt wire sealed in glass & $\begin{array}{l}\text { Bovine leukemia } \\
\text { virus glycoproteins }\end{array}$ & Ultrapure water & $\begin{array}{l}\mathrm{NI} \\
\mathrm{NI}\end{array}$ & [203] \\
\hline MIP & Pyrrole & PGE & DNA & Acetate buffer & $\begin{array}{l}\text { NI } \\
\text { NI }\end{array}$ & [204] \\
\hline
\end{tabular}

*: depending on the MIP content. LOD: limit of detection. NI: not informed. ABPE: acetylene black paste. BDD: boron doped diamond. C: carbon. CPE: carbon paste electrode. EIS: electrochemical impedance spectroscopy. EPPG: edge plane pyrolytic graphite. GCE: glassy carbon electrode. GO: graphene oxide. IL: ionic liquid. ITO: indium tin oxide. ITO/PET: indium tin oxide coated polyethylene terephthalate. mGEC: magneto-electrode based on graphite-epoxy composite. MWCNT: multi-walled carbon nanotube. NP: nanoparticle. NT: nanotube. PBS: phosphate buffer solution. PGE: pencil graphite electrode. QD: quantum dot. RGO: reduced graphene oxide. SPE: Screen-printed electrode. SWV: square wave voltammetry.

\subsubsection{MIP-Electrochemical Sensors in Environmental Applications}

The detection and quantification of pollutants in environmental samples, such as natural waters and soils, as well as in aquatic organisms, is necessary to determine their fate and transport. Most environmental sensors have targeted endocrine disruptors, pesticides and pharmaceuticals. They occur in the environment at trace concentrations in complex matrices, which further challenges the analysis. A large number of efforts have been devoted to developing novel and economical determination and quantification alternatives. Some particularly illustrating examples are briefly described below.

A MIP sol-gel film formed by multi-walled carbon nanotubes (MWCNTs) and the conductive polymer Nafion was prepared for the determination of 2-nonylphenol, a xenobiotic endocrine disruptor [42]. The use of Nafion increased the homogeneity of the MIP sol-gel and improved the peak current of the electrochemical probe. APTES, phenyltrimethoxysilane, and a combination of these were used as monomers. A pH of 7 provided optimal electrostatic binding of the target in the MIP, due to the degree of ionization of 2-nonylphenol. The stability and repeatability tests showed a relative standard deviation of the MIP solgel response of only $3.6 \%$ for twenty successive measurements, and a higher current response of the electrode to the 2-nonylphenol when compared with its structural analogues. However, the effect of physical or chemical interactions in real samples, such as suspended solids, was not reported. Deng et al. [170] proposed a voltammetric sensor to detect bisphenol A, another endocrine disruptor of concern. An acetylene black paste electrode was prepared with acetylene black and paraffin and covered with $2 \mu \mathrm{L}$ of a film of bisphenol A (10 mM), chitosan, and graphene oxide $(0.25 \mathrm{mg} / \mathrm{mL})$, using $\mathrm{H}_{2} \mathrm{SO}_{4}$ to crosslink the chitosan. Removal of the template was achieved by cyclic voltammetry $(\mathrm{CV})$, and graphene oxide was reduced to obtain the final electrode. The best electrochemical determinations were obtained at $\mathrm{pH} 3$ and with immersion of the electrode in the solution for $3 \mathrm{~min}$. Six electrodes were produced to check reproducibility. The sensor was stably stored in $\mathrm{H}_{2} \mathrm{SO}_{4}$ at room temperature for 10 days. Repeatability was tested by using the same electrode ten times, removing the target between measurements by cyclic potential sweeps. Selectivity was good over other compounds, including various phenolic molecules, and no interference from ions was detected. Des Azevedo et al. [201] developed a MIPhybrid electrochemical sensor for the detection of $17 \beta$-estradiol (E2) in water, based on $\mathrm{N}$-phenylethylene diamine methacrylamide as bifunctional monomer, MAA as functional monomer, $N, N^{\prime}$-diethyldithiocarbamic acid benzyl ester as initiator, EGDMA as crosslinker, and acetonitrile as porogen. However, the short linear range and low LOD would require improvements to be useful for real environmental samples. To test the sensor selectivity, $17 \alpha$-estradiol ( $\alpha$-E2), progesterone, and (P4) estriol (E3) were used, since the three are 
structurally related to E2. No binding occurred between the sensor and $\alpha$-E2, nor P4, showing good selectivity and specificity. However, E3 at high concentration was detected by the sensor, exhibiting a lack of selectivity due to its high structural similarity with E2.

Pesticides in environmental samples usually require arduous sample pretreatment followed by chromatographic techniques; therefore, MIPs have been proposed as a low cost, portable, and easy-to-use alternative. A MIP-based sensor for the organophosphorus pesticide methidathion was prepared using the template, the functional monomer MBA, and EGDMA in a molar ratio of 1:4:20, together with AIBN in dimethylformamide [134]. Bulk polymerization took place in an oil bath at $80^{\circ} \mathrm{C}$ for $12 \mathrm{~h}$, after which the monolith was ground and sieved, and the template was removed by Soxhlet extraction. The MIP particles were mixed with a TMOS sol-gel solution and deposited on a carbon screenprinted electrode (SPE). Good reproducibility and selectivity were obtained, since the sensor did not respond to other organophosphorus pesticides tested. Regeneration was achieved for five successive measurements by efficiently extracting the target with a mixture of methanol and acid. The sensor was evaluated in tap water, and although satisfactory, this relatively clean environment is far less challenging than those expected in natural water samples. Anirudhan and Alexander [145] reported a new synthesis to obtain a MIP-based potentiometric sensor to determine lindane ( $\gamma$-hexachlorocyclohexane), an organochlorine pesticide, using MWCNTs. The potentiometric sensor was prepared using an active electrode of $\mathrm{Cu}$ and a calomel electrode as reference. First, MWCNTs were mixed with glycidyl methacrylate, which contains the epoxide functional groups essential to develop polarity in the nanotubes. Then, these MWCNTs were vinylated and polymerized with the template to obtain a covalently bonded complex matrix on their surface. The optimal $\mathrm{pH}$ was 3 ; the chlorine atoms found in the pesticide were electrostatically attracted to protonated carboxyl groups of the MWCNTs, increasing the sensitivity. The selectivity was tested using a potentiometric method and linear sweep voltammetry (LSV), with organophosphorus and organochlorine compounds, resulting in a high response compared to the other pesticides. The authors applied the sensor to the detection of lindane in fruits, vegetables, and water, but an extraction step from complex matrices was used. The sensor was able to detect the target, but the pretreatment added complexity and limited its application in situ.

Magnetic MIP nanoparticles, consisting of a magnetite core, were fabricated for the extraction, cleaning, and pre-concentration of the organophosphorus pesticide, methyl parathion in fish [178]. The nanoparticles were obtained by co-precipitation of $\mathrm{Fe}^{2+}$ and $\mathrm{Fe}^{3+}$, and a $\mathrm{SiO}_{2}$ shell, that were reacted with TEOS to acquire $\mathrm{OH}$ groups. In this way, the magnetic core-shell particles reacted with an acrylic group, obtaining active $\mathrm{C}=\mathrm{C}$ groups that, in turn, were polymerized with the template in toluene. MAA, EGDMA, and AIBN were included as functional monomer, crosslinking agent, and initiator, respectively. The template was removed by Soxhlet extraction with methanol and acetic acid. The best working conditions were at $\mathrm{pH} 2$ and maximum loading was reached after $1 \mathrm{~h}$. Selectivity tests were performed with similar structures, confirming specific binding. The sensor could be reused for six measurements, though binding capacity was lost to some extent.

Significant efforts were directed towards the analysis of pollutants, in particular pharmaceuticals, in wastewater. Warwick et al. [138] proposed coupling MIPs with a capacitance sensor to offer a more economical alternative to the colorimetric method used in the detection of phosphates in wastewater. The selected template was phenylphosphonic acid, instead of $\mathrm{HPO}_{4}{ }^{2-}$ and $\mathrm{H}_{2} \mathrm{PO}_{4}{ }^{-}$, to avoid solubility problems, since the synthesis required organic solvents. EGDMA was the crosslinker, AIBN the initiator, and $N$-allylthiourea the functional monomer. The template and the monomer were added in a molar ratio of 2:1. Polymerization was performed under UV light for $20 \mathrm{~min}$, and the MIP was ground and sieved before Soxhlet extraction of the template molecules. The sensor exhibited good performance at $\mathrm{pH} 6.5-8$, emulating that of domestic wastewaters. Selectivity was studied, finding out that sulphate, nitrate, and chloride did not interfere with the detection of phosphate, thus offering stability for longer times. Reusability of the MIP membrane was 
achieved for up to ten times. However, the LOD and LOQ were too high, above the typical concentrations of phosphate in wastewater. $\mathrm{N}$-formylamphetamine, an intermediate and an indicator of amphetamine synthesis, was detected in wastewaters using MIP particles that were obtained on the gold surface of a wafer electrode, with a mixture of two functional monomers, HEMA and IA, along with EGDMA, in a reaction started with AIBN at $60{ }^{\circ} \mathrm{C}$ [136]. The monomers contained methylene and carbonyl groups to bond to the phenyl and amide groups of the template. The sensor was tested in buffer solutions, but no tests in real wastewaters were performed. Zhao et al. [162] developed a MIP modified boron-doped diamond (BDD) electrode to quantitatively determine the presence of the antibiotic sulfamethoxazole in surface waters. The MIP-BDD electrode was prepared by five electropolymerization cycles using pyrrole $(40 \mathrm{mM})$ as a functional monomer on a $\mathrm{BDD}$ electrode in the presence of the template $(20 \mathrm{mM})$ at $\mathrm{pH} 7.5$. The selectivity of the sensor was high; however, occurrence of sulfamethoxazole in aquatic ecosystems [205] and wastewaters $[206,207]$ is at much lower concentrations than the detection limit. A MIP for the detection of metronidazole, a drug to prevent parasites in fish and poultry, was designed by $\mathrm{Gu}$ et al. [173], combining molecular imprinting with mimetic enzymes. Melamine was both the functional monomer, capable of forming hydrogen bonds, and the molecular host of the mimetic enzyme. Cu was the active center, since its complexes present enzyme-like activity; Au nanoparticles amplified the signal and casted with chitosan on a glassy carbon electrode (GCE). In parallel, $\mathrm{CuSO}_{4}$ in acid and melamine in water were mixed until a complex between them was formed, and then the template was included along with $\mathrm{NaCl}$. After the polymer was electrodeposited on the electrode, the template was removed by ten scan cycles in Britton-Robinson buffer. Recognition and catalytic activity were successfully achieved, as well as good reproducibility and stability. Selectivity over molecules with similar electrochemical response but different in shape, size, and functional groups was good thanks to the nature of the imprinting sites; however, when the tested compound had a similar structure, the interference was greater, evidencing the lack of specificity of the MIP.

\subsubsection{MIP-Electrochemical Sensors in Biomedical Applications}

A large number of sensors were designed with the intention of improving dose control or to measure pharmaceutical drugs in tablets, injections, or physiological fluids. However, most sensors were validated only in aqueous solutions or simulated environments, much simpler than the matrices they would encounter in biomedical applications.

Ji et al. [39] combined a MIP film with carboxylic functionalized MWCNTs GCE and Au nanoparticles to measure cholesterol concentrations. To prepare the MIP, the electrode was first immersed in a solution of the functional monomer, p-aminothiophenol, $\mathrm{HAuCl}_{4}$, and cholesterol to form the pre-polymerization complex, due to the strong interactions between the amino functional monomer and the acidic template. The polymer was formed through bonds between $\mathrm{Au}$ in the crosslinker and sulfur in the monomer, and the template was then removed by a solution of $\mathrm{HCl}$ in ethanol-water. Detection of the target was manifested by an increase in charge-transfer impedance, as well as a reduction in the differential pulse voltammetry current peak. The selectivity of this sensor was satisfactory and it remained stable after a month of storage at room temperature in $\mathrm{HCl}$. Despite the promising results, the authors recognized that its application in clinical analysis/diagnosis would require further study. Rosy et al. [139] electropolymerized the functional monomer o-aminophenol on a GCE together with the target norepinephrine and $\mathrm{NaClO}_{4}$ for diagnosis and drug quality control. After the imprinting, the template was removed with $\mathrm{H}_{2} \mathrm{SO}_{4}$, capable of breaking the hydrogen bonds between o-aminophenol and the polymer. The sensor was tested in phosphate buffer solution (PBS) and selectivity, stability, and reproducibility were studied, with satisfactory results. A potentiometric sensor for the recognition of imidocarb dipropionate was synthesized by Rizk and coworkers [146], based on a potential difference between a MIP membrane sensor electrode and a reference electrode of $\mathrm{Ag} / \mathrm{AgCl}$. The prepolymerization solution was a mixture of the template, MAA, EGDMA, benzoyl 
peroxide, and acetonitrile that was bulk polymerized. Although the final application was to detect the target in the liver and kidney of animals, the sensor was only tested in aqueous solutions. A MIP sensor for the anticoagulant drug heparin was prepared using heparin as a template, MAA as a functional monomer, AIBN as an initiator, and EGDMA as a crosslinker [147]. The GCE was coated with the prepared solution and polymerization was performed under UV light. The effect of $\mathrm{pH}$ and prepolymerization solution formulation was tested, and the sensor was evaluated only in laboratory prepared solutions of the target. A MIP sensor for captopril, a drug used to treat hypertension, was designed using a GCE and a carbon paste electrode (CPE) [149]. The MIP particles were obtained by precipitation polymerization; captopril was dissolved in a mixture of acetonitrile and ethanol, then MAA was incorporated, followed by EGDMA and AIBN, and reacted for $12 \mathrm{~h}$ in an oil bath at $80^{\circ} \mathrm{C}$. The template was eluted with a solution of methanol and acetic acid. Good stability and reusability were obtained after twenty cycles of operation and selectivity over other interfering drugs was satisfactory, but tests were conducted in deionized water solutions. Li et al. [194] proposed a three-dimensional MIP modified voltammetry-based sensor for the detection of epinephrine. $\mathrm{ZnO}$ nanorods grew vertically on indium tin oxide (ITO) coated polyethylene terephthalate film by electrodeposition of pyrrole in the presence of the template and $\mathrm{LiClO}_{4}$; the template was eluted by immersion in $\mathrm{KCl}$ and PBS. Unfortunately, the saturation of imprinted sites prevented the linearity of the oxidation peak current vs. epinephrine in the range of 1-2000 $\mu \mathrm{M}$. Although good selectivity facing structural analogues and repeatability were obtained, the response was not linear and the sensitivity was too low for physiologically relevant concentrations. Da Silva et al. [161] worked on a sensor to detect the antibacterial chemical norfloxacin in human urine. MWCNTs were deposited on the surface of a GCE, which was afterwards coated with a MIP film via cyclic voltammetry of polypyrrole. The human urine samples were spiked with the chemical and diluted $50 \%$ with sulfuric acid. The sensor was exposed to chemical structure analogs to the target, and interference was manifested when exposed to enrofloxacin. The MIPs were reused for thirty measurement cycles without significant change in the current response signal.

The rapid detection of biomarkers in a point of care setting is highly desirable for improved diagnosis and treatment and several authors reported efforts towards this goal. Electrochemical sensors have been reported for the detection of DNA [204] and proteins [203], although, in general, they were only tested in aqueous solutions and specificity and nonspecific interactions were not explored. For example, Yola and Atar [189] developed a sensor to detect the cardiac biomarker Troponin-I in plasma. The template and pyrrole were imprinted on BN quantum dots coated GCE by cyclic voltammetry. No interference was detected due to the plasma; selectivity over other proteins in plasma, stability, and reproducibility were high. Moreira et al. [196] reported a point-of-care disposable sensor for myoglobin, another cardiac biomarker. The template and functional monomer (o-aminophenol) were adsorbed on a gold SPE and electropolymerized. The template was removed by digestion of the MIP in proteinase $\mathrm{K}$ that cleaved peptide bonds under mild conditions, hence avoiding alterations in the polymer. However, due to the small size of the protein, only those molecules on the outer surface could be removed, leaving the vast majority entrapped inside the film. The sensor was tested in MES buffer and synthetic urine; in this context, the results obtained were fast, sensitive, and selective. Other large molecules of interest for which MIP electrochemical biosensors have been reported are the clinical biomarkers for diagnosis of cancer and other cardiovascular diseases [208]. The imprinting of high molecular weight compounds, e.g., biomacromolecules, confronts particular additional challenges given by the size and complexity of the structure and conformation of the target, leading to binding sites with heterogeneous affinities, hindered target removal, and solvents that induce conformational changes in proteins (unfolding or denaturation) [209]. The epitope imprinting technique has been proposed to overcome these issues: in this approach, only a small but characteristic portion of the biomolecule is 
imprinted. However, the specificity problem may still arise if the epitope is not unique to the intended target [209].

\subsection{Optical Sensors}

Optical sensors rely on a change in an optical property, such as light absorption, fluorescence, light scattering, refractive index, or reflection, as the target rebinds to the MIP sites. This function is sufficient in the case of optically detectable targets, but, if the substance lacks optical properties, an indirect method of detection is needed. Alternatively, the change in color, fluorescence, etc., may occur after the complex formation with the MIP [210]. Different optical techniques can be used in these sensors, such as ultraviolet/visible spectroscopy (UV/Vis), fluorescence, chemiluminescence, surface plasmon resonance (SPR), and Raman scattering (RS) [211]. Conventional RS sensitivity is low because of its small cross-section, thus not attaining detection at trace level. In surfaceenhanced Raman scattering (SERS), metallic nanoparticles are included ( $\mathrm{Ag}$, $\mathrm{Au}$, etc.) to act as the active substrate where the target adsorbs with a notorious enhancement in the magnetic field [212]. Photoelectrochemical (PEC) sensors merge UV/Vis method with electrochemical sensors, by enabling amperometric detection thanks to photoirradiation. The measurements are based on electron transfer among an analyte, a semiconductor, and an electrode, coupled with photoirradiation [213]. Table 2 summarizes some reports of MIP-based optical sensors for environmental and biomedical applications.

Table 2. MIP-based optical sensors in environmental and biomedical applications.

\begin{tabular}{|c|c|c|c|c|c|c|}
\hline \multirow{2}{*}{ Sensor } & \multirow{2}{*}{$\begin{array}{l}\text { Form or } \\
\text { Electrode }\end{array}$} & \multirow{2}{*}{ Functional Monomer } & \multirow{2}{*}{ Target } & \multirow{2}{*}{ Sample } & Linear Range & \multirow{2}{*}{ Ref. } \\
\hline & & & & & LOD & \\
\hline \multicolumn{7}{|c|}{ UV/Visible spectroscopy } \\
\hline $\mathrm{ZnFe}_{2} \mathrm{O}_{4} / \mathrm{MIP}$ & Membrane & Acrylamide (AM) & Bisphenol A & Ultrapure water & $\begin{array}{l}10-1000 \mathrm{nM} \\
6.18 \mathrm{nM}\end{array}$ & [214] \\
\hline MIP & Membrane & Itaconic acid (IA) & Phenol & $\begin{array}{l}\text { Drinking, natural, and } \\
\text { wastewater }\end{array}$ & $\begin{array}{c}50 \mathrm{nM}-10 \mathrm{mM} \\
50 \mathrm{nM}\end{array}$ & [215] \\
\hline MIP & Paper & $\begin{array}{c}\text { MAA + polyethylenimine } \\
(\text { PEI) }\end{array}$ & $\mathrm{Cd}(\mathrm{II})$ & Lake water & $\begin{array}{l}1-100 \mathrm{ng} / \mathrm{mL} \\
0.4 \mathrm{ng} / \mathrm{mL}\end{array}$ & [216] \\
\hline MIP & Particles & $\begin{array}{l}\text { 2-acrylamido-2-methyl-1- } \\
\text { propanesulfonic acid } \\
\text { (AMPSA) }\end{array}$ & Basic red 9 & Ultrapure water & $\begin{array}{l}\text { NI } \\
\text { NI }\end{array}$ & [217] \\
\hline Magnetite-MIP & Microspheres & MAA & Rhodamine B & Wine & $\begin{array}{c}0.04-1.4 \mu \mathrm{g} / \mathrm{mL} \\
1.05 \mu \mathrm{g} / \mathrm{L}\end{array}$ & [218] \\
\hline $\begin{array}{l}\text { MIP-Graphitic } \\
\qquad \mathrm{C}_{3} \mathrm{~N}_{4}\end{array}$ & FTO & 4-vinylpyridine (4-VP) & Bisphenol A & Bottled water & $\begin{array}{c}5-200 \mu \mathrm{M} \\
1.3 \mu \mathrm{M}\end{array}$ & [219] \\
\hline MIP & Film & Acrylic acid (AA) & 2-butoxyethanol & $\begin{array}{l}\text { Hydraulic fracking } \\
\text { wastewater }\end{array}$ & $\begin{array}{c}10 \mathrm{ppb}-100 \mathrm{ppm} \\
3.4 \mathrm{ppb}\end{array}$ & [220] \\
\hline MIP & Film & AA & Testosterone & Ultrapure water & $\begin{array}{c}5-100 \mathrm{ppb} \\
4.2 \mathrm{ppb}\end{array}$ & [221] \\
\hline Magnetic MIP & NP & Triallyl isocyanurate & Sterigmatocystin & Wheat & $\begin{array}{l}1.8-25 \mathrm{ng} / \mathrm{g} \\
0.63 \mathrm{ng} / \mathrm{g}\end{array}$ & [222] \\
\hline \multicolumn{7}{|c|}{ Fluorescence } \\
\hline MIP/Mn-ZnS QD & NP & $\begin{array}{l}\text { 4-vinylphenylboronic acid } \\
\text { and methyl methacrylate }\end{array}$ & $\alpha$-fetoprotein & Human serum & $\begin{array}{l}0.05-10 \mu \mathrm{g} / \mathrm{L} \\
48 \mathrm{ng} / \mathrm{L}\end{array}$ & [223] \\
\hline $\mathrm{C}$ dots-MIP & NP & MAA & Sterigmatocystin & Millet, rice, corn & $\begin{array}{c}0.05-2 \mathrm{mg} / \mathrm{L} \\
0.019 \mathrm{mg} / \mathrm{L}\end{array}$ & [224] \\
\hline $\mathrm{MIP} / \mathrm{Mn}-\mathrm{ZnS} \mathrm{QD}$ & NP & $\begin{array}{c}3- \\
\text { aminopropyltriethoxysilane }\end{array}$ & Nicosulfuron & River water & $\begin{array}{l}12-6000 \mathrm{nM} \\
1.1 \mathrm{nM}\end{array}$ & [225] \\
\hline $\mathrm{MIP} / \mathrm{POF}$ & Capillary tube & $\begin{array}{l}\text { (APTES) } \\
\text { MAA }\end{array}$ & Bisphenol A & $\begin{array}{l}\text { Mineral water bottle in } \\
\text { ethanol and water } \\
\text { solutions }\end{array}$ & $\begin{array}{c}3 \times 10^{-9}-5 \times 10^{-6} \\
\mathrm{~g} / \mathrm{mL} \\
1.7 \times 10^{-9} \mathrm{~g} / \mathrm{mL}\end{array}$ & [226] \\
\hline $\begin{array}{l}\text { Allyl } \\
\text { fluorescein-MIP }\end{array}$ & Microspheres & $\begin{array}{l}\text { 4-vinylphenylboronic acid+ } \\
\text { MAA (VPBA/MAA) }\end{array}$ & Tetracycline & $\begin{array}{l}\text { Etracycline hydrochloride, } \\
\text { human serum, swine urine }\end{array}$ & $\begin{array}{l}4.26-150 \mathrm{nM} \\
4.26 \mathrm{nM}\end{array}$ & [227] \\
\hline MIP-IL & Microspheres & $\begin{array}{l}\text { 3-(anthracen-9-ylmethyl)-1- } \\
\text { vinyl-1H-imidazol-3-ium } \\
\text { chloride (Fluorescent IL } \\
\text { monomer) }\end{array}$ & p-nitroaniline & River, lake, and tap water & $\begin{array}{c}10 \mathrm{nM}-10 \mathrm{M} \\
9 \mathrm{nM}\end{array}$ & [228] \\
\hline 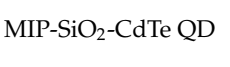 & Composite & Acrylamide (AM) & Sulfanilamide & River water & $\begin{array}{l}2-30 \mu \mathrm{M} \\
0.17 \mu \mathrm{M}\end{array}$ & [229] \\
\hline CdTe QD-MIP & Composite & $\mathrm{AM}$ & $\lambda$-cyhalothrin & River water & $\begin{array}{c}0.1-16 \mu \mathrm{M} \\
0.03 \mu \mathrm{M}\end{array}$ & [230] \\
\hline
\end{tabular}


Table 2. Cont.

\begin{tabular}{|c|c|c|c|c|c|c|}
\hline \multirow[t]{2}{*}{ Sensor } & \multirow{2}{*}{$\begin{array}{l}\text { Form or } \\
\text { Electrode }\end{array}$} & \multirow[t]{2}{*}{ Functional Monomer } & \multirow[t]{2}{*}{ Target } & \multirow[t]{2}{*}{ Sample } & Linear Range & \multirow[t]{2}{*}{ Ref. } \\
\hline & & & & & LOD & \\
\hline \multicolumn{7}{|c|}{ Fluorescence } \\
\hline MIP & $\begin{array}{l}\text { Core-shell } \\
\text { particles }\end{array}$ & methacrylamide & $\begin{array}{l}2,4- \\
\text { diclorophenoxyacetic } \\
\text { acid }\end{array}$ & River water & $\begin{array}{l}20 \mathrm{nM}-5 \mu \mathrm{M} \\
20 \mathrm{nM}\end{array}$ & [231] \\
\hline MIP-C dots & $\begin{array}{l}\text { Mesoporous } \\
\text { structure }\end{array}$ & Amino-CDs & TNT & Tap water, soil & $\begin{array}{l}0.5-20 \mu \mathrm{M} \\
17 \mathrm{nM}\end{array}$ & [232] \\
\hline MIP & Hollow NP & $\mathrm{AM}$ & $\lambda$-cyhalothrin & Canal water & $\begin{array}{l}10.26-160 \mathrm{nM} \\
10.26 \mathrm{nM}\end{array}$ & [233] \\
\hline $\mathrm{Fe}_{3} \mathrm{O}_{4}-\mathrm{SiO}_{2}-\mathrm{MIP}$ & $\begin{array}{l}\text { Core-shell } \\
\text { magnetic NP }\end{array}$ & $\begin{array}{c}\text { nitrobenzoxadiazole } \\
\text { fluorophore (NBD-MA) }\end{array}$ & Rhodamine B & Methanol & $\begin{array}{c}\mathrm{NI} \\
10^{-8} \mathrm{M}\end{array}$ & [234] \\
\hline CdTe/CdS QD-MIP & $\begin{array}{l}\text { Mesoporous } \\
\text { structure }\end{array}$ & $\begin{array}{c}3- \\
\text { Aminopropyltriethoxysilane } \\
\text { (APTES) }\end{array}$ & Diniconazole & Soil, river and wastewater & $\begin{array}{l}20-160 \mu \mathrm{g} / \mathrm{L} \\
6.4 \mu \mathrm{g} / \mathrm{L}\end{array}$ & [235] \\
\hline MIP & $\mathrm{Au} N C$ & APTES & Bisphenol A & Seawater & $\begin{array}{c}0.1-13 \mu \mathrm{M} \\
0.1 \mu \mathrm{M}\end{array}$ & [236] \\
\hline MIP & Microplate & Dansyl methacrylate & Bisphenol A & $\begin{array}{l}\text { Tap, river and distilled } \\
\text { water }\end{array}$ & $\begin{array}{c}10-2000 \mu \mathrm{gg} / \mathrm{L} \\
3 \mu \mathrm{g} / \mathrm{L}\end{array}$ & [237] \\
\hline QD-MIP & Composite & Acrylamide (AM) & Cyphenothrin & River water & $\begin{array}{c}0.1-80 \mu \mathrm{M} \\
9 \mathrm{nM}\end{array}$ & [238] \\
\hline MIP-C dots & Nanocomposite & APTES & Bisphenol A & River water & $\begin{array}{c}10^{-7}-4.2 \times 10^{-6} \mathrm{M} \\
3 \times 10^{-8} \mathrm{M}\end{array}$ & [239] \\
\hline MIP-ZnO QD & Nanocomposite & APTES & $\begin{array}{l}\text { Thioridazine } \\
\text { hydrochloride }\end{array}$ & Human plasma & $\begin{array}{l}4-120 \mathrm{nM} \\
0.43 \mathrm{nM}\end{array}$ & [240] \\
\hline MIP-C dots & Paper & MAA & $\begin{array}{c}\text { 3- } \\
\text { monochloropropane- } \\
\text { 1,2-diol }\end{array}$ & Soy sauce & $\begin{array}{l}1-150 \mathrm{ng} / \mathrm{mL} \\
0.6 \mathrm{ng} / \mathrm{mL}\end{array}$ & [241] \\
\hline MIP-QD & Composite & APTES & $\begin{array}{l}\text { Tetrabromobisphenol- } \\
\text { A }\end{array}$ & Electronic waste & $\begin{array}{l}1-60 \mathrm{ng} / \mathrm{mL} \\
3.6 \mathrm{ng} / \mathrm{mL}\end{array}$ & [242] \\
\hline MIP-Graphene QD & Composite & $\begin{array}{c}3- \\
\text { aminopropyltriethoxysilane } \\
\text { (APTS) }\end{array}$ & Omidazole & Human plasma & $\begin{array}{c}0.75-30 \mu \mathrm{M} \\
0.24 \mu \mathrm{M}\end{array}$ & [243] \\
\hline $\begin{array}{c}\text { MIP-CdSeS/ZnS } \\
\text { QD }\end{array}$ & Glass slide & 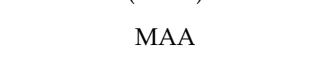 & Sulfasalazine & Human plasma and urine & $\begin{array}{c}0.02-1.5 \mu \mathrm{M} \\
0.0071 \mu \mathrm{M}\end{array}$ & [244] \\
\hline $\mathrm{SiH}_{4}-\mathrm{C}$ dots-MIP & Nanocomposite & APTES & Acetamiprid & Wastewater, apple & $\begin{array}{c}7-107 \mathrm{nM} \\
2 \mathrm{nM}\end{array}$ & [245] \\
\hline QD-MIP & Core-shell & APTES & $\begin{array}{l}\text { Perfluorooctanoic } \\
\text { acid }\end{array}$ & Tap and river water & $\begin{array}{l}0.25-15 \mu \mathrm{M} \\
25 \mathrm{nM}\end{array}$ & [246] \\
\hline MIP-C dots & Film & $\begin{array}{c}\operatorname{Poly}(\text { methyl } \\
\text { acrylate-co-acrylic acid) }\end{array}$ & 2,4- dinitrotoluene & Ultrapure water & $\begin{array}{l}1-15 \mathrm{ppm} \\
0.28 \mathrm{ppm}\end{array}$ & [247] \\
\hline MIP-C dots & Film & $\begin{array}{l}\text { Acrylic acid(AA) + methyl } \\
\text { acrylate (MA) }\end{array}$ & 2,4- dinitrotoluene & Lake and tap water & $\begin{array}{l}1-15 \mathrm{ppm} \\
0.28 \mathrm{ppm}\end{array}$ & [248] \\
\hline MIP-QD & Nanocomposite & APTES & Thiamphenicol & Milk & $\begin{array}{c}0.10-100 \mu \mathrm{M} \\
0.04 \mu \mathrm{M}\end{array}$ & [249] \\
\hline MIP-C dots & Film & APTES & Cetricine & Urine, saliva & $\begin{array}{c}0.5-500 \mathrm{ng} / \mathrm{mL} \\
0.41 \mathrm{ng} / \mathrm{mL}\end{array}$ & [250] \\
\hline \multicolumn{7}{|c|}{ Chemiluminescence } \\
\hline $\begin{array}{l}\text { MIP/Cromatography } \\
\text { paper }\end{array}$ & Paper strip & MAA & Dichlorvos & $\begin{array}{l}\text { Cabbage leaves, tomato } \\
\text { skin }\end{array}$ & $\begin{array}{c}0.003-10 \mu \mathrm{g} / \mathrm{mL} \\
0.8 \mathrm{ng} / \mathrm{mL}\end{array}$ & [251] \\
\hline $\begin{array}{l}\text { Silanized magnetic } \\
\text { graphene- } \\
\text { MIP/Capillary }\end{array}$ & Capillary tube & Acrylamide (AM) & Dopamine & $\begin{array}{l}\text { Urine, dopamine } \\
\text { hydrochloride injection }\end{array}$ & $\begin{array}{c}8-200 \mathrm{ng} / \mathrm{mL} \\
1.5 \mathrm{ng} / \mathrm{mL} \\
3.84 \times 10^{-8}-2.08 \times\end{array}$ & [252] \\
\hline MIP-Magnetic NP & $\mathrm{NP}$ & MAA & Dibutyl phthalate & Juice & $\begin{array}{c}10^{-5} \mathrm{M} \\
2.09 \times 10^{-9} \mathrm{M}\end{array}$ & [253] \\
\hline $\begin{array}{l}\mathrm{MoS}_{2} \text {-Graphene } \\
\text { QD-MIP }\end{array}$ & GCE & o-phenyl-enediamine (o-PD) & $\begin{array}{l}\text { 2-methyl-4- } \\
\text { chlorophenoxyacetic } \\
\text { acid }\end{array}$ & Oat, tap, and lake water & $\begin{array}{c}10 \mathrm{pM}-0.1 \mu \mathrm{M} \\
5.5 \mathrm{pM}\end{array}$ & [254] \\
\hline $\begin{array}{c}\text { MIP-Au } \\
\text { NP-CdSe/ZnS QD }\end{array}$ & Au electrode & Thioanilin & $\begin{array}{c}\text { 2-methyl-4- } \\
\text { chlorophenoxyacetic } \\
\text { acid }\end{array}$ & $\begin{array}{l}\text { Tap, lake and river water, } \\
\text { oat, rice }\end{array}$ & $\begin{array}{c}10 \mathrm{pM}-50 \mu \mathrm{M} \\
2.2 \mathrm{nM}\end{array}$ & [255] \\
\hline $\begin{array}{l}\text { MIP/Chromatography } \\
\text { paper }\end{array}$ & Paper disk & $\mathrm{AM}$ & $\begin{array}{l}2,4- \\
\text { dichlorophenoxyacetic }\end{array}$ & Tap and lake water & $\begin{array}{c}5 \mathrm{pM}-10 \mu \mathrm{M} \\
1 \mathrm{pM}\end{array}$ & [256] \\
\hline $\begin{array}{l}\text { CdTe QD-Chitosan- } \\
\text { GO-Magnetite-MIP }\end{array}$ & NP & MAA & $\begin{array}{l}\text { acid } \\
\text { Chrysoidine }\end{array}$ & Paper, fabric & $\begin{array}{l}10^{-7}-10^{-5} \mathrm{M} \\
3.2 \times 10^{-9} \mathrm{M}\end{array}$ & [257] \\
\hline $\begin{array}{l}\text { MIP-Aptamer-CdS } \\
\text { QD }\end{array}$ & SPE & Dopamine & Diethylstilbestrol & Fish & $\begin{array}{l}0.3-100,000 \mathrm{pg} / \mathrm{mL} \\
0.1 \mathrm{pg} / \mathrm{mL}\end{array}$ & [258] \\
\hline MIP & $\mathrm{CPE}$ & MAA & Azithromycin & Blood serum, urine & $\begin{array}{c}10^{-10}-4 \times 10^{-7} \mathrm{M} \\
2.3 \times 10^{-11} \mathrm{M}\end{array}$ & [259] \\
\hline $\begin{array}{l}\text { MIP-Cu } \\
\text { nanoclusters }\end{array}$ & GCE & o-phenylenediamine & Enrofloxacin & $\begin{array}{l}\text { Meat, lake water, bovine } \\
\text { serum, human urine }\end{array}$ & $\begin{array}{l}0.1 \mathrm{nM}-1 \mu \mathrm{M} \\
27 \mathrm{pM}\end{array}$ & [260] \\
\hline
\end{tabular}


Table 2. Cont.

\begin{tabular}{|c|c|c|c|c|c|c|}
\hline \multirow[t]{2}{*}{ Sensor } & \multirow{2}{*}{$\begin{array}{l}\text { Form or } \\
\text { Electrode }\end{array}$} & \multirow[t]{2}{*}{ Functional Monomer } & \multirow[t]{2}{*}{ Target } & \multirow[t]{2}{*}{ Sample } & Linear Range & \multirow[t]{2}{*}{ Ref. } \\
\hline & & & & & LOD & \\
\hline \multicolumn{7}{|c|}{ Surface plasmon resonance } \\
\hline $\mathrm{MIP} / \mathrm{POF}$ & Optical fiber & MAA & L-nicotine & Ultrapure water & $\begin{array}{c}1.86 \times 10^{-4}-10^{-3} \mathrm{M} \\
1.86 \times 10^{-4} \mathrm{M}\end{array}$ & [261] \\
\hline $\mathrm{MIP} / \mathrm{POF}$ & Optical fiber & MAA & Furfural & Transformer oil & $\begin{array}{l}9-30 \mathrm{ppb} \\
9 \mathrm{ppb}\end{array}$ & [262] \\
\hline $\mathrm{MIP} / \mathrm{Ag}-\mathrm{POF}$ & Optical fiber & Polyaniline & Ascorbic acid & Ultrapure water & $\begin{array}{c}10^{-8}-10^{-7} ; 10^{-6}-10^{-4} \\
\mathrm{M} \\
1.28 \times 10^{-10} \mathrm{M}\end{array}$ & [263] \\
\hline $\mathrm{MIP} / \mathrm{Ag}-\mathrm{POF}$ & Optical fiber & MAA & Profenofos & PBS & $\begin{array}{c}10^{-4} \mu \mathrm{g} / \mathrm{L} \\
2.5 \times 10^{-6} \mu \mathrm{g} / \mathrm{L}\end{array}$ & [264] \\
\hline MIP & Film & Methacrylamide & Amoxicillin & Tap water, PBS & $\begin{array}{c}0.1-2.6 \mathrm{nM} \\
73 \mathrm{pM}\end{array}$ & [265] \\
\hline MIP & Film & MAA & Histamine & Fish & $\begin{array}{c}25-1000 \mu \mathrm{g} / \mathrm{L} \\
25 \mu \mathrm{g} / \mathrm{L}\end{array}$ & [266] \\
\hline MIP & NP & $\begin{array}{l}N \text {-methacryloyl-(L)-histidine } \\
\text { methyl ester }\end{array}$ & Histamine & Canned tuna, cheese & $\begin{array}{c}0.001-10 \mu \mathrm{g} / \mathrm{L} \\
0.58 \mathrm{ng} / \mathrm{L}\end{array}$ & [267] \\
\hline MIP & NP & Biotinylated phenylalanine & $\begin{array}{l}\text { Prostate-specific } \\
\text { antigen }\end{array}$ & Blood & $\begin{array}{c}0.001-0.2 \mathrm{ng} / \mathrm{mL} \\
1 \mathrm{pg} / \mathrm{mL}\end{array}$ & [268] \\
\hline MIP & Nanofilm & $\begin{array}{l}N \text {-methacryloyl-(L)- } \\
\text { tryptophan methyl } \\
\text { ester }\end{array}$ & $\begin{array}{l}\text { Carbofuran, } \\
\text { dimethoate }\end{array}$ & River water & $\begin{array}{c}10-1000 \mathrm{ng} / \mathrm{L} \\
7.11 \text { (carbofuran); } 8.37 \\
\text { (dimethoate) ng/L }\end{array}$ & [269] \\
\hline MIP-Au NP & Film & $\begin{array}{c}N \text {-methacryloyl-(L)- } \\
\text { phenylalanine }\end{array}$ & Aflatoxin B1 & Corn, peanut & $\begin{array}{c}0.0001-10 \mathrm{ng} / \mathrm{mL} \\
1.04 \mathrm{pg} / \mathrm{mL}\end{array}$ & [270] \\
\hline MIP-Ag NP & Film & $\begin{array}{l}N \text {-methacryloyl-(L)-histidine } \\
\text { methyl ester }\end{array}$ & Escherichia coli & Mimic urine & $\begin{array}{c}15-1,500,000 \mathrm{CFU} / \mathrm{mL} \\
0.57 \mathrm{CFU} / \mathrm{mL}\end{array}$ & [271] \\
\hline \multicolumn{7}{|c|}{ Raman scattering } \\
\hline $\begin{array}{c}\text { MIP } \\
\text { microspheres/Au- } \\
\text { Klarite } \\
\text { substrate }\end{array}$ & Microsphres & MAA & Nicotine & Acetonitrile & $\begin{array}{l}\mathrm{NI} \\
\mathrm{NI}\end{array}$ & [272] \\
\hline $\begin{array}{l}\text { MIP/Au-Disulfide- } \\
\text { derivatized } \\
\text { perfluorophenylazide- } \\
\text { Klarite } \\
\text { substrate }\end{array}$ & NP & MAA & Propranolol & Human urine & $\begin{array}{c}\mathrm{NI} \\
7.7 \times 10^{-4} \mathrm{M}\end{array}$ & [273] \\
\hline $\begin{array}{l}\mathrm{MIP} / \mathrm{Ag} \text { dentrite } \\
\text { nanostructure } \\
\text { substrate }\end{array}$ & Fine particles & MAA & Melamine & Milk & $\begin{array}{c}0.005-0.05 \mathrm{mM} \\
0.012 \mathrm{mM}\end{array}$ & [274] \\
\hline Ag-MIP & $\begin{array}{l}\text { Core-shell } \\
\text { nanoplates }\end{array}$ & Methacrylamide & Rhodamine B & Ultrapure water & $\begin{array}{c}\mathrm{NI} \\
10^{-12} \mathrm{M}\end{array}$ & [275] \\
\hline Ag-MIP & Core-shell & $\mathrm{AM}$ & Rhodamine 6G & Water & $\begin{array}{c}10^{-12}-10^{-6} \mathrm{M} \\
10^{-14} \mathrm{M}\end{array}$ & [276] \\
\hline Ag-MIP & Core-shell & MAA & $\begin{array}{l}\text { 4-mercaptobenzoic } \\
\text { acid }\end{array}$ & Water & $\begin{array}{c}\mathrm{NI} \\
10^{-15} \mathrm{M}\end{array}$ & [277] \\
\hline $\begin{array}{l}\text { Boronate affinity } \\
\text { MIP-Boronate } \\
\text { affinity SERS }\end{array}$ & Sandwich assay & APTES & $\alpha$-fetoprotein & Human serum & $\begin{array}{l}0.001-10 \mu \mathrm{g} / \mathrm{mL} \\
\quad 0.1 \mathrm{ng} / \mathrm{mL}\end{array}$ & [278] \\
\hline MIP-Au NP & Core-shell & $\begin{array}{l}\text { 3-(triethoxysilyl)propyl } \\
\text { isocyanate (TEPIC) }\end{array}$ & Bisphenol A & $\begin{array}{l}\text { Surface water, } \\
\text { plastic-bottled beverages }\end{array}$ & $\begin{array}{c}2.2 \times 10^{-6}-10^{-4} \mathrm{M} \\
5.37 \times 10^{-7} \mathrm{M}\end{array}$ & [279] \\
\hline MIP-Magnetic NP & Core-shell & MAA & Ciprofloxacin & Fetal bovine serum & $\begin{array}{c}10^{-7}-10^{-4} \mathrm{M} \\
10^{-7} \mathrm{M}\end{array}$ & [280] \\
\hline $\mathrm{MIP}-\mathrm{SiO}_{2}-\mathrm{AgNP}$ & Core-shell & $\begin{array}{l}\text { tetraethyl orthosilicate } \\
\text { (TEOS) }\end{array}$ & Bisphenol A & Tap and lake water, milk & $\begin{array}{c}1.75 \times 10^{-11}-1.75 \times \\
10^{-6} \mathrm{M} \\
1.46 \times 10^{-11} \mathrm{M}\end{array}$ & [281] \\
\hline MIP-Ag & Core-shell & Acrylamide & Glibenclamide & Water & $\begin{array}{c}1 \mathrm{ng} / \mathrm{mL}-100 \mu \mathrm{g} / \mathrm{mL} \\
1 \mathrm{ng} / \mathrm{mL}\end{array}$ & [282] \\
\hline $\mathrm{SiO}_{2} / \mathrm{rGO} / \mathrm{Au}-\mathrm{MIP}$ & NP & Methacrylic acid, acrylamide & 2,6-dichlorophenol & Water & $\begin{array}{c}1-100 \mathrm{nM} \\
0.02 \mathrm{nM}\end{array}$ & [283] \\
\hline MIP-Au NP & Core-shell & Phenyltrimethoxysilane & L-Phenylalanine & Bovine serum & $\begin{array}{c}10^{-8}-10^{-4} \mathrm{M} \\
10^{-9} \mathrm{M}\end{array}$ & [284] \\
\hline MIP-Au NP & Fine particles & UV/visible spe & oscopy. Raman scatte & Apple juice & $\begin{array}{l}\text { NA (Color); } 0.005-1 \\
\text { mg/L (SERS) } \\
0.005 \text { (Color); } 0.0012 \\
\text { (SERS) } \mathrm{mg} / \mathrm{L}\end{array}$ & [212] \\
\hline \multicolumn{7}{|c|}{ Fluorescence. Raman scattering } \\
\hline Magnetic MIP & NP & $\begin{array}{l}\text { Poly(ethylene-co-vinyl } \\
\text { alcohol) }\end{array}$ & Phenylalanine & Human urine & $\begin{array}{c}\text { 7-100 (F); } 5-800 \\
\mu \mathrm{g} / \mathrm{mL}(\mathrm{RS}) \\
\mathrm{NI}(\mathrm{F}) ; 0.4 \mu \mathrm{g} / \mathrm{mL} \\
\text { (RS) }\end{array}$ & [285] \\
\hline
\end{tabular}


Table 2. Cont

\begin{tabular}{|c|c|c|c|c|c|c|}
\hline \multirow[t]{2}{*}{ Sensor } & \multirow{2}{*}{$\begin{array}{l}\text { Form or } \\
\text { Electrode }\end{array}$} & \multirow{2}{*}{ Functional Monomer } & \multirow[t]{2}{*}{ Target } & \multirow[t]{2}{*}{ Sample } & Linear Range & \multirow{2}{*}{ Ref. } \\
\hline & & & & & LOD & \\
\hline \multicolumn{7}{|c|}{ Photoelectrochemical } \\
\hline MIP & ITO & Pyrrole & Bisphenol A & River and tap water & $\begin{array}{c}2-500 \mathrm{nM} \\
1.2 \mathrm{nM}\end{array}$ & [41] \\
\hline $\begin{array}{c}\text { MIP-Au NP-ZnO } \\
\text { NP }\end{array}$ & Paper & Pyrrole & Pentacholorophenol & Drinking and river water & $\begin{array}{l}0.01-100 \mathrm{ng} / \mathrm{mL} \\
4 \mathrm{pg} / \mathrm{mL}\end{array}$ & [286] \\
\hline $\begin{array}{l}\text { F graphitic } \\
\mathrm{C}_{3} \mathrm{~N}_{4} \text {-MIP }\end{array}$ & FTO & 4-vinylpyridine (4-VP) & $\mathrm{Cr}(\mathrm{VI})$ & Tap and river water & $\begin{array}{c}0.01-100 \mathrm{ppb} \\
0.006 \mathrm{ppb}\end{array}$ & [287] \\
\hline $\mathrm{MIP} / \mathrm{TiO}_{2} \mathrm{NT}$ & Thin film & o-phenyl-enediamine (o-PD) & Lindane & Drinking and river water & $\begin{array}{c}0.1-10 \mu \mathrm{M} \\
0.03 \mu \mathrm{M}\end{array}$ & [213] \\
\hline $\begin{array}{c}\mathrm{MIP} / \mathrm{Au} \mathrm{NP}-\mathrm{TiO}_{2} \\
\text { NT }\end{array}$ & Thin film & o-PD & Chlorpyrifos & Green vegetables & $\begin{array}{c}0.05-10 \mu \mathrm{M} \\
0.96 \mathrm{nM}\end{array}$ & [288] \\
\hline $\mathrm{MIP} / \mathrm{TiO}_{2} \mathrm{NT}$ & Vertical NT & Pyrrole & Bisphenol A & $\begin{array}{l}\text { Drinking, river, and tap } \\
\text { water, domestic sewage }\end{array}$ & $\begin{array}{l}4.5-108 \mathrm{nM} \\
2 \mathrm{nM}\end{array}$ & [289] \\
\hline $\mathrm{MIP}-\mathrm{TiO}_{2}$ & Nanorods & P-aminothiophenol (ATP) & Chlorpyrifos & Drinking and river water & $\begin{array}{l}0.01-100 \mathrm{ng} / \mathrm{mL} \\
7.4 \mathrm{pg} / \mathrm{mL}\end{array}$ & [290] \\
\hline MIP-TiO ${ }_{2}$ & $\begin{array}{l}\text { FTO glass } \\
\text { substrate }\end{array}$ & APTES & RNase B & Human serum & $\begin{array}{c}0.5 \mathrm{pM}-2 \mu \mathrm{M} \\
0.12 \mathrm{pM}\end{array}$ & [291] \\
\hline $\begin{array}{l}\text { MIP-CdTe QD-Au } \\
\text { NP }\end{array}$ & Paper/SPE & AAM & S-fenvalerate & $\begin{array}{l}\text { Apple, pear, tomato, } \\
\text { cucumber }\end{array}$ & $\begin{array}{l}10^{-8}-10^{-6} \mathrm{M} \\
3.2 \times 10^{-9} \mathrm{M}\end{array}$ & [292] \\
\hline $\mathrm{MIP}-\mathrm{TiO}_{2}-\mathrm{MWCNT}$ & Core-shell & $\mathrm{TiO} 2$ & Microcystin-LR & Tap, pond, and river water & $\begin{array}{c}1 \mathrm{pM}-3 \mathrm{nM} \\
0.4 \mathrm{pM}\end{array}$ & [293] \\
\hline MIP & Porous carrier & $\begin{array}{l}\text { 4-vinylpyridine (VP) and } \\
N \text {-isopropylacrylamide }\end{array}$ & Bisphenol A & Seawater, yogurt & $\begin{array}{c}\mathrm{NI} \\
11.14 \mu \mathrm{g} / \mathrm{L}\end{array}$ & [294] \\
\hline MIP & Strip/SPE & $\begin{array}{l}\text { (NIPAM) } \\
\text { AM }\end{array}$ & $\begin{array}{l}\text { Perfluorooctane } \\
\text { sulfonyl fluoride }\end{array}$ & Tap, river, and lake water & $\begin{array}{c}0.05-500 \mathrm{ppb} \\
0.01 \mathrm{ppb}\end{array}$ & [295] \\
\hline $\begin{array}{l}\text { Aptamer-MIP-GO- } \\
\qquad \mathrm{C}_{3} \mathrm{~N}_{4}\end{array}$ & FTO & Aptamer & Kanamycin & $\mathrm{Na}_{2} \mathrm{SO}_{4}$ solution & $\begin{array}{c}1-230 \mathrm{nM} \\
0.2 \mathrm{nM}\end{array}$ & [296] \\
\hline $\begin{array}{l}\text { MIP-BiIO nanoflake } \\
\text { array }\end{array}$ & Nanofibers & Chitosan & $\begin{array}{l}\text { Triphenyl } \\
\text { Phosphate }\end{array}$ & Tap, river, and lake water & $\begin{array}{l}0.01-500 \mathrm{ng} / \mathrm{mL} \\
0.008 \mathrm{ng} / \mathrm{mL}\end{array}$ & [297] \\
\hline $\mathrm{MIP} / \mathrm{TiO}_{2} \mathrm{NT}$ & Vertical NT & $\mathrm{AM}$ & $\begin{array}{l}\text { Perfluorooctane } \\
\text { sulfonate }\end{array}$ & $\begin{array}{l}\text { Tap, river, and mountain } \\
\text { water }\end{array}$ & $\begin{array}{l}0.5-10 \mu \mathrm{M} \\
86 \mathrm{ng} / \mathrm{mL}\end{array}$ & [298] \\
\hline $\begin{array}{c}\text { CdS } \\
\text { dots-Graphene-MIP }\end{array}$ & FTO & Pyrrole & 4-aminophenol & Lake water & $\begin{array}{c}5 \times 10^{-8}-3.5 \times 10^{-6} \\
\mathrm{M} \\
2.3 \times 10^{-8} \mathrm{M}\end{array}$ & [299] \\
\hline $\begin{array}{l}\text { MIP-AgI NP-BiIO } \\
\text { nanoflake array }\end{array}$ & FTO & $\mathrm{AM}$ & $\begin{array}{l}\text { Perfluorooctanic } \\
\text { acid }\end{array}$ & Tap and river water & $\begin{array}{l}0.02-1000 \mathrm{ppb} \\
0.01 \mathrm{ppb}\end{array}$ & [300] \\
\hline Glass/ZnO/MIP & Nanorods & Pyrrole & Bisphenol S & PBS & $\begin{array}{c}2.5-12.5 \mu \mathrm{M} \\
0.7 \mu \mathrm{M}\end{array}$ & [301] \\
\hline
\end{tabular}

LOD: limit of detection. NA: not achieved. NI: not informed. CPE: carbon paste electrode. FTO: F-doped SnO 2 . IL: ionic liquid. ITO: indium tin oxide. GCE: glassy carbon electrode. GO: graphene oxide. MWCNT: multi-walled carbon nanotube. NC: nanocluster. NP: nanoparticle. NT: nanotube. PBS: phosphate buffer solution. POF: plastic optical fiber. QD: quantum dot. rGO: reduced graphene oxide. SERS: surface enhanced Raman scattering. SPE: Screen-printed electrode.

\subsubsection{MIP-Based Optical Sensors in Environmental Applications}

A selection of innovative MIP optical sensors is presented below, with emphasis on two main contaminant groups for the environmental field: pesticides and industrial waste. Sensors that rely on a change of color of the material upon exposure to the target compound are particularly attractive for environmental applications, as they can offer naked-eye readings in the field. However, the usual low levels of the relevant pollutant and the complex and diverse matrices encountered are major obstacles.

Dyes present in textile and paper industrial effluents are toxic to humans and the environment and require monitoring. A MIP-based evanescent wave fiber sensor for the basic red 9 (BR9) was synthesized by bulk polymerization, using 2-acrylamido-2-methyl-1propanesulfonic acid as a functional monomer and EGDMA as a crosslinker. The amount of dye in the samples was correlated to the absorbed light in aqueous solutions [217]. However, the device was not tested in real effluents. In another approach, Duan et al. [257] proposed a sensor based on chemiluminescence resonance energy transfer in CdTe quantum dots@ luminol nanomaterials combined with chitosan/graphene oxide-magnetite-MIP for detection of chrysoidine. The CdTe QDs@ luminol amplified the chemiluminescence signal, whereas chitosan and graphene oxide improved the adsorption. When tested in the presence of coexisting substances, the sensor showed decreased specificity. A carbon dot functionalized fluorescent MIP was fabricated for the detection of dinitrotoluene in groundwater with AA as the functional monomer, EDGMA, and AIBN [247]. The sensor was tested in spiked lake water and tap water samples, with overall acceptable performance, 
although organic matter interfered with the fluorescence signal. This drawback was partially overcome by a non-labeled photonic MIP sensor, with the optical active structure obtained by conducting the polymerization in the pore space of a sacrificial colloidal crystal: the method allowed the detection of 2-butoxyethanol wastewater from hydraulic fracking operations. The sensor performed well, but the polyacrylic acid polymer was severely damaged by the wastewater after each use and could not be recycled [220].

Bisphenol A (BPA) is another chemical of concern that was the target of several MIP-sensors. A fluorescence MIP sensor was fabricated combining silica-coated fluorescent carbon dots via sol-gel polymerization to be used in river water samples [239]. Xue et al. [279] fabricated surface-imprinted core-shell Au nanoparticles of BPA for detection by SERS in surface water and plastic bottled beverages. Both sensors showed good performance in laboratory prepared standard solutions, and acceptable measurements in a handful of real samples, although low $\mathrm{pH}$ beverages resulted in very low recoveries. A photonic sensor was proposed by Kadhem at al. [221] for the detection of testosterone in natural water, another example of endocrine disrupting chemicals in the environment. A mixture of AA, EDGMA, AIBN, and the target was polymerized inside a silica particles crystal that provided the optically active morphology. Rebinding of the target produced swelling of the polymer and consequent change in the wavelength of the reflected light. The sensor showed minimal non-specific adsorption and good reusability in laboratory-made test samples.

Several optical MIP-based sensors have been reported for the detection of pesticides and veterinary antibiotics. Zhao et al. [212] fabricated a MIP for atrazine extraction from apple juice by bulk polymerization of MAA, EGDMA, chloroform, and AIBN, reacted in an oil bath at $60^{\circ} \mathrm{C}$ for $24 \mathrm{~h}$. The obtained monolith was ground and sieved, the template removed by Soxhlet extraction, and particles were packed into a solid-phase-extraction cartridge. The pretreated solution was analyzed by a colorimetric method based on $\mathrm{Au}$ nanoparticles for rapid detection by SERS, but it did not reach a low LOD nor a linearity in the response. A sensor for the herbicide 2,4-dichlorophenoxyacetic acid was developed by Wagner et al. [231] using fluorescent core-shell MIP particles in a 3-dimensional microfluidic system for droplet extraction from the water matrix and mixture with the MIP, that reached a LOD below the drinking water guideline. However, nonspecific binding due to matrix effects were observed. Electrochemiluminescent graphene quantum dots were proposed for the detection of the herbicide 2-methyl-4-chlorophenoxyacetic acid [254]. A layer of hybrid nanocomposite of graphene quantum dots and $\mathrm{MoS}_{2}$, in a mass ratio of 2:3, was coated on a GCE upon which the MIP was synthetized by cyclic voltammetry with 2methyl-4-chlorophenoxyacetic acid as the selected template and the functional monomer o-PD. The template removal was accomplished by shaking in methanol and acetic acid. Samples were subjected to an extensive pre-treatment for the extraction of the target from water and food samples, and redissolution in PBS ( $\mathrm{pH}$ 7.4). Competitive adsorption tests demonstrated good selectivity as well as good stability.

\subsubsection{MIP-Based Optical Sensors in Biomedical Applications}

Efforts in the biomedical field are primarily aimed at developing point-of-care devices that provide non-invasive, safe, and fast detection, as well as quantification of drugs for dose control, especially when serious side effects may appear.

The detection of proteins by MIP-based sensors has been reported by fluorescence, surface plasmon resonance, and changes in the Bragg diffraction of optically active imprinted hydrogels. SPR showed good resistance to fouling and the consequent non-specific binding in biological matrices, but the technique requires relatively more expensive equipment than the measurement of Bragg diffraction. On the other hand, the response of photonic hydrogels can be affected by ionic strength or $\mathrm{pH}$ (buffers), possibly limiting their application to protein sensing [302].

Sensors for the biomarker $\alpha$-fetoprotein were developed by Tan et al. [223] based on fluorescence and Ye et al. [278] on SERS. The fluorescent sensor was a combination 
of ZnS quantum dots and MIPs of functional monomers methyl methacrylate and 4vinylphenylboronic. The two functional monomers were chosen so the boronic acid group would form a covalent bond with the template, giving a cyclic ester in alkaline medium; $\gamma$-methacryloxypropyl linked both the organic and inorganic phases, enabling the sol-gel polymerization. Serum samples were added to PBS and mixed with the MIP particles, a carbonate buffer, and, finally, diluted with water. Although high loading capacity and selectivity were obtained, the synthesis process was rather complex and the samples needed pretreatment. The SERS methodology involved Ag nanoparticles labeled MIPs with boronate affinity [278]. Specificity for $\alpha$-fetoprotein was studied as well as cross-reactivity, finding out that the highest values were obtained for glycoproteins of similar molecular weight as the target. The glycoprotein RNase B was detected by a photoelectrochemical approach, given by three-dimensional anatase hierarchically cactus-like arrays vertically grown on a FTO substrate for PEC detection [291]. The electrochromic indicator employed was a Prussian blue electrode that discolored to Prussian white, as a function of the target concentration. The MIP was fabricated on $\mathrm{TiO}_{2}$ arrays amino-functionalized with APTES, then immersed in a solution of 2,4-difluoro-3-formylphenylboronic acid and $\mathrm{NaBH}_{3} \mathrm{CN}$, washed with water and, finally, washed in a solution of $\mathrm{NH}_{4} \mathrm{HCO}_{3}$ at $\mathrm{pH} 8.5$ containing the templates. The electrode was washed with $\mathrm{NH}_{4} \mathrm{HCO}_{3}$ solution and subsequently imprinted in ethanol where TEOS was added. Finally, washing with ethanol-acetic acid removed the template. The PEC measurement was performed by allowing the sample to be bound to the modified electrode, and then connecting to the Prussian blue electrode in PBS ( $\mathrm{pH}$ 7.4). The discolored electrode was taken out and the absorbance measured after light irradiation for $10 \mathrm{~s}$. Stability, selectivity, and reproducibility were studied with acceptable results.

Duan et al. [252] used chemiluminescence in the detection of dopamine, useful in the diagnosis of Parkinsonism. This work is based on silanized $\mathrm{Fe}_{3} \mathrm{O}_{4}$ magnetic nanoparticlegraphene oxide MIP. The magnetic graphene oxide was included in an ethanol solution of dopamine and acrylamide with EGDMA and AIBN. A solution of methanol and acetic acid was used to extract the template. A major inconvenience was caused by epinephrine, that attached to the imprinted cavities. The detection of phenylalanine in urine for diagnosis purposes was conducted by magnetic MIP nanoparticles with fluorescence spectrophotometry and RS [285]. Iron oxide nanoparticles were added to ethylene-co-vinyl alcoholdimethylsulfoxide solution, and thereafter mixed with phenylalanine for non-covalent imprinting; the template was removed by ethanol and acetic acid. Tests on urine samples showed cross-reactivity with structurally similar compounds, in particular tyrosine and L-3,4-dihydroxyphenylalanine.

A sensor for the antipsychotic drug thioridazine was made from MIP-coated fluorescent $\mathrm{ZnO}$ quantum dots [240]. The quantum dots were obtained by a core precipitation from $\mathrm{Zn}\left(\mathrm{CH}_{3} \mathrm{COO}\right)_{2}$ with $\mathrm{NaOH}$ and a silica shell. The MIP was prepared on the quantum dots by reverse microemulsion with TEOS, and $\mathrm{NH}_{4} \mathrm{OH}$ to hydrolyze the monomer; afterwards, the template and APTES were introduced into the solution and acetone to break the emulsion. The dots were then subjected to centrifugation and the precipitate washed with a mixture of ethanol and acetonitrile to remove the template. Tests were performed on plasma samples with a pretreatment to remove proteins and resuspension in a suitable buffer solution. Selectivity over the remaining compounds was demonstrated for the tested samples.

Significant efforts were devoted to the detection of antibiotics. A sensor for the detection of ornidazole, combining graphene quantum dots and silica MIPs, was fabricated by citric acid pyrolysis with APTES, followed by sol-gel polymerization of the target and silica matrix; methanol was used to remove the target molecules [243]. The sensor was evaluated in human plasma, pretreated to separate the proteins, and adjusted to $\mathrm{pH}$ 9. Repeatability, selectivity, and reproducibility were satisfactory, as well as the low interference by ions commonly found in serum. Fluorescent quantum dots were employed for the detection of sulfasalazine [244]. An amino-functionalized glass slide was incubated with APTES, 
covered with semi-conductor CdSeS/ZnS quantum dots, and, finally, functionalized with methacryloxypropyl trimethoxysilane to enhance adhesion. To prepare the MIP, the glass was immersed in a mixture of sulfasalazine, MAA, EGDMA, and AIBN in acetonitrile and toluene. Secondly, it was heated to $60^{\circ} \mathrm{C}$ for $2 \mathrm{~h}$ and washed with methanol and acetic acid to remove unreacted monomers and the template. Plasma and urine samples were centrifuged and the supernatant diluted prior measurement. Reusability, selectivity over structural analogues, and reproducibility were satisfactory.

\section{Technical Barriers to Commercialization of MIP Sensors and Devices}

Molecular imprinted polymers are a promising technology in the environmental and biomedical sectors. The reported LODs comprise environmental and toxicological relevant concentrations of many chemicals of concern. Their stability and simplicity of use in comparison with more established analytical techniques make them particularly attractive for field measurements or contamination monitoring in remote areas without access to traditional chemical laboratory facilities. In the medical field, point of care diagnostics using biosensing based on enzymes and antibodies have introduced significant improvements in glucose monitoring for diabetics or pregnancy tests, providing convenience, privacy, and lower costs. MIPs have the potential to introduce similar benefits to many other conditions, since they can be fabricated for a wide range of targets, including biomarkers for cancer, infectious, and inflammatory diseases. The approach will be transformative for both medical and environmental fields; however, and in spite of the large number of patents filed worldwide on MIPs, the technology is still mostly restricted to academic laboratories [303]. Nevertheless, there is an unquestionable market need for such a device. We have conducted an extensive customer discovery study funded by the US National Science Foundation that highlighted the demand for a point of care analytical device for hormone analysis in blood from all stakeholders: health care providers, clinical laboratories, and patients.

The translation of MIP technology from the laboratory to final product has been hindered by technological challenges in two main areas: the device design and fabrication process and the scale up of the manufacturing process. A useful device should not only capture the target compound specifically from diverse and complex matrices, where most of the current research efforts have been directed, but should also provide the user with a system to read and store the measured data. The system should be small, preferably handheld, user friendly, fast, and low cost. Recent advances in electronics and optical interfaces have contributed to the solution of this problem, and interfaces for smart phones to work with MIP-based sensors have been suggested for diagnostics/analysis platforms. A fully developed and calibrated MIP-based system is still lacking, and a significant research investment will be required for its full development.

The manufacturing process, and in particular the scale up from the academic laboratory to large batches of MIP materials, is, in our view, the main obstacle to commercialization. The lack of reproducibility of MIPs between batches, both with respect to their morphological and chemical binding properties, is the main drawback. The issue seems to be related to insufficient control of fabrication parameters, which becomes extremely challenging given the complex synthesis of some of the proposed sensors. In addition, academic laboratory protocols for manufacturing usually need to be completely reengineered when shifting to large-scale manufacturing in an industrial setting, adding more research and development tasks before a successful prototype can be obtained and requiring large investments in the early stages of product development.

Finally, mass production of MIPs will consume considerable amounts of template, which can be either unavailable or economically unfeasible. A process for target recovery and purification after elution from the newly synthesized MIPs will be needed in order to reuse the target molecule in different batches. 


\section{Summary and Conclusions}

The search for better sensitivity and selectivity has driven significant research in the field of materials science and engineering, and many sensors have been reported with diverse nanomaterials and sophisticated manufacturing processes. The new materials are well characterized and calibrated in laboratory made solutions, with some examples of assays in real samples. Although these attempts may improve the analytical performance, they also complicate commercialization efforts due to cost and fabrication complexity.

Currently, commercialization of MIPs is focused on niche markets in biotechnology, as well as analytical and separation chemistry. Several start-ups derived from academic laboratories are currently commercializing the technology. Semorex (Fanwood, NJ, US) specializes in protein-imprinted polymers for the elimination of specific proteins from the gastrointestinal tract in the therapy of Crohn's disease. MIP Technologies AB (Lund, Sweden) offers tailored purification resins. AFFINISEP (Petit Couronne, France) has developed a range of solid-phase-extraction phases used in food and environment analysis, life sciences, and pharmaceuticals. MIP Diagnostics Ltd. (Bedford, UK) commercializes different types of tailor-made MIPs for in vitro diagnostics. Biotage (Cardiff, UK) designs resins for the removal of low-level contaminants, or extraction of high value desirables, from any process, particularly for the food, beverage, flavor, and fragrance industries. In addition, the life science technologies and specialty chemicals company Sigma-Aldrich (St Louis, MO, US) offers solid-phase-extraction materials based on MIP technology.

There are significant obstacles to the introduction of MIP-based sensors to the consumer market. First, the interference of structural analog compounds to the target molecule is a general problem in the literature, and some of the complex materials and synthesis processes proposed to avoid this issue are not viable for large-scale production due to the extra cost and manufacturing restrictions. A reengineering of the fabrication methods will be required in most cases, as laboratory bench protocols are converted to industrial manufacturing processes. We have reviewed numerous examples of MIP-based sensors that achieved the required LOD and linear range as needed for biological and environmental use; however, the majority of these sensors are fabricated following costly and complicated methods. In order for these materials to reach the consumer, the optimization of the production method is of utmost importance so they can be efficiently mass manufactured. Secondly, while tests in real samples are included in most of the reviewed articles, they are limited to just a few promising results. Natural waters and wastewaters are the most common matrices in environmental sensing, and their composition can vary widely in $\mathrm{pH}$, dissolved solids concentration, and organic matter content. Clinical trials of MIP-based sensors are the necessary first step for regulatory approval and validation of any biomedical device. Large scale testing is an expensive and time-consuming endeavor, and constitutes one of the most important roadblocks for the advancement of the technology. Although the challenges are significant, the promises of MIP technology continue to attract numerous application-minded researchers to the field, working towards the achievement of its full potential.

Author Contributions: Conceptualization, A.J.K. and M.M.F.d.C.; methodology, A.J.K.; writing—original draft preparation, A.J.K.; writing — review and editing, A.J.K., G.J.G. and M.M.F.d.C.; visualization, A.J.K. and G.J.G.; supervision, M.M.F.d.C. All authors have read and agreed to the published version of the manuscript.

Funding: This research received no external funding; A.J.K. is grateful to The Higher Committee for Education Development (HCED) and Environmental Research Center, University of Technology, Baghdad, Iraq, for a doctoral fellowship.

Informed Consent Statement: Not applicable.

Data Availability Statement: Not applicable.

Conflicts of Interest: The authors declare no conflict of interest. 


\section{References}

1. Haupt, K.; Linares, A.V.; Bompart, M.; Bui, B.T.S. Molecularly Imprinted Polymers. Top. Curr. Chem. 2011, 325, 1-28. [CrossRef]

2. Beltran, A.; Borrull, F.; Marcé-Recasens, R.M.; Cormack, P. Molecularly-imprinted polymers: Useful sorbents for selective extractions. TrAC Trends Anal. Chem. 2010, 29, 1363-1375. [CrossRef]

3. Wulff, G.; Grobe-Einsler, R.; Vesper, W.; Sarhan, A. Enzyme-analogue built polymers, 5. On the specificity distribution of chiral cavities prepared in synthetic polymers. Makromol. Chem. 1977, 178, 2817-2825. [CrossRef]

4. Whitcombe, M.J.; Rodriguez, M.E.; Villar, P.; Vulfson, E.N. A New Method for the Introduction of Recognition Site Functionality into Polymers Prepared by Molecular Imprinting: Synthesis and Characterization of Polymeric Receptors for Cholesterol. J. Am. Chem. Soc. 1995, 117, 7105-7111. [CrossRef]

5. Vlatakis, G.; Andersson, L.I.; Muller, R.S.; Mosbach, K. Drug assay using antibody mimics made by molecular imprinting. Nature 1993, 361, 645-647. [CrossRef] [PubMed]

6. Arshady, R.; Mosbach, K. Synthesis of substrate-selective polymers by host-guest polymerization. Makromol. Chem. 1981, 182, 687-692. [CrossRef]

7. Alexander, C.; Andersson, H.; Andersson, L.I.; Ansell, R.J.; Kirsch, N.; Nicholls, I.A.; O’Mahony, J.; Whitcombe, M.J. Molecular imprinting science and technology: A survey of the literature for the years up to and including 2003. J. Mol. Recognit. 2006, 19, 106-180. [CrossRef]

8. Kupai, J.; Razali, M.; Buyuktiryaki, S.; Kecili, R.; Szekely, G. Long-term stability and reusability of molecularly imprinted polymers. Polym. Chem. 2016, 8, 666-673. [CrossRef]

9. Wulff, G.; Sarhan, A. Über die Anwendung von enzymanalog gebauten Polymeren zur Racemattrennung. Angew. Chem. 1972, 84, 364. [CrossRef]

10. Vasapollo, G.; del Sole, R.; Mergola, L.; Lazzoi, M.R.; Scardino, A.; Scorrano, S.; Mele, G.; Vasapollo, G.; del Sole, R.; Mergola, L.; et al. Molecularly Imprinted Polymers: Present and Future Prospective. Int. J. Mol. Sci. 2011, 12, 5908-5945. [CrossRef] [PubMed]

11. Asman, S.; Mohamad, S.; Sarih, N.M. Exploiting $\beta$-Cyclodextrin in Molecular Imprinting for Achieving Recognition of Benzylparaben in Aqueous Media. Int. J. Mol. Sci. 2015, 16, 3656-3676. [CrossRef]

12. Zaidi, S.A. Molecular imprinted polymers as drug delivery vehicles. Drug Deliv. 2014, 23, 2262-2271. [CrossRef] [PubMed]

13. Pardo, A.; Mespouille, L.; Dubois, P.; Blankert, B.; Duez, P. Molecularly Imprinted Polymers: Compromise between Flexibility and Rigidity for Improving Capture of Template Analogues. Chem. A Eur. J. 2014, 20, 3500-3509. [CrossRef] [PubMed]

14. Caro, E.; Marce, R.; Borrull, F.; Cormack, P.; Sherrington, D. Application of molecularly imprinted polymers to solid-phase extraction of compounds from environmental and biological samples. TrAC Trends Anal. Chem. 2006, 25, 143-154. [CrossRef]

15. Sanagi, M.M.; Salleh, S.; Ibrahim, W.A.W.; Abu Naim, A.; Hermawan, D.; Miskam, M.; Hussain, I.; Aboul-Enein, H.Y. Molecularly imprinted polymer solid-phase extraction for the analysis of organophosphorus pesticides in fruit samples. J. Food Compos. Anal. 2013, 32, 155-161. [CrossRef]

16. Bitar, M.; Cayot, P.; Bou-Maroun, E. Molecularly imprinted polymer solid phase extraction of fungicides from wine samples. Anal. Methods 2014, 6, 6467-6472. [CrossRef]

17. Wang, G.N.; Yang, K.; Liu, H.Z.; Feng, M.X.; Wang, J.P. Molecularly imprinted polymer-based solid phase extraction combined high performance liquid chromatography for determination of fluoroquinolones in milk. Anal. Methods 2016, 8, 5511-5518. [CrossRef]

18. Yang, Y.; Yu, J.; Yin, J.; Shao, B.; Zhang, J. Molecularly Imprinted Solid-Phase Extraction for Selective Extraction of Bisphenol Analogues in Beverages and Canned Food. J. Agric. Food Chem. 2014, 62, 11130-11137. [CrossRef]

19. Baltrons, O.; López-Mesas, M.; Palet, C.; Le Derf, F.; Portet-Koltalo, F. Molecularly imprinted polymer-liquid chromatography/fluorescence for the selective clean-up of hydroxylated polycyclic aromatic hydrocarbons in soils. Anal. Methods 2013, 5, 6297-6305. [CrossRef]

20. Panahi, H.A.; Mahabadi, S.A. Application of Molecularly Imprinted Polymer for Extraction and Determination of Nalidixic Acid by High-Performance Liquid Chromatography. Sep. Sci. Technol. 2014, 50, 683-689. [CrossRef]

21. Liu, Q.; Wan, J.; Cao, X. Synthesis of core-shell molecularly imprinted polymers (MIP) for spiramycin I and their application in MIP chromatography. Process. Biochem. 2018, 70, 168-178. [CrossRef]

22. Yang, S.; Wang, Y.; Jiang, Y.; Li, S.; Liu, W. Molecularly Imprinted Polymers for the Identification and Separation of Chiral Drugs and Biomolecules. Polymers 2016, 8, 216. [CrossRef]

23. Li, Z.W.; Jia, X.; Xu, C.M.; Liu, L.; Fu, D.C. Chiral Separation of Amlodipine and its Enantiomer on a Molecularly Imprinted Polymer-Based Stationary Phase. Adv. Mater. Res. 2013, 706-708, 36-39. [CrossRef]

24. Orozco, J.; Cortés, A.; Cheng, G.; Sattayasamitsathit, S.; Gao, W.; Feng, X.; Shen, Y.; Wang, J. Molecularly Imprinted Polymer-Based Catalytic Micromotors for Selective Protein Transport. J. Am. Chem. Soc. 2013, 135, 5336-5339. [CrossRef]

25. Li, S.; Zhu, M.; Whitcombe, M.J.; Piletsky, S.A.; Turner, A.P.F. Molecularly Imprinted Polymers for Enzyme-like Catalysis: Principle, Design, and Applications. In Molecularly Imprinted Catalysts; Li, S., Cao, S., Piletsky, S.A., Turner, A.P.F., Eds.; Elsevier: Amsterdam, The Netherlands, 2016; pp. 1-17.

26. Czulak, J.; Jakubiak-Marcinkowska, A.; Trochimczuk, A. Polymer Catalysts Imprinted with Metal Ions as Biomimics of Metalloenzymes. Adv. Mater. Sci. Eng. 2013, 2013, 464265. [CrossRef]

27. Wei, W.; Zhou, T.; Wu, S.; Shen, X.; Zhu, M.; Li, S. An enzyme-like imprinted-polymer reactor with segregated quantum confinements for a tandem catalyst. RSC Adv. 2018, 8, 1610-1620. [CrossRef] 
28. Li, S.; Ge, Y.; Turner, A.P.F. A Catalytic and Positively Thermosensitive Molecularly Imprinted Polymer. Adv. Funct. Mater. 2011, 21, 1194-1200. [CrossRef]

29. Kurczewska, J.; Cegłowski, M.; Pecyna, P.; Ratajczak, M.; Gajecka, M.; Schroeder, G. Molecularly imprinted polymer as drug delivery carrier in alginate dressing. Mater. Lett. 2017, 201, 46-49. [CrossRef]

30. Fareghi, A.R.; Moghadam, P.N.; Khalafy, J.; Bahram, M.; Moghtader, M. Preparation of a new molecularly imprinted polymer based on self-crosslinkable cellulose acrylate in aqueous solution: A drug delivery system for furosemide. J. Appl. Polym. Sci. 2017, 134, 45581. [CrossRef]

31. Anirudhan, T.; Divya, P.; Nima, J. Silylated montmorillonite based molecularly imprinted polymer for the selective binding and controlled release of thiamine hydrochloride. React. Funct. Polym. 2013, 73, 1144-1155. [CrossRef]

32. Mohajeri, S.A.; Tabassi, S.A.S.; Moghadam, M.H. Preparation of a pH-sensitive pantoprazole-imprinted polymer and evaluation of its drug-binding and -releasing properties. Sci. China Ser. B Chem. 2014, 57, 857-865. [CrossRef]

33. Kempe, H.; Pujolràs, A.P.; Kempe, M. Molecularly Imprinted Polymer Nanocarriers for Sustained Release of Erythromycin. Pharm. Res. 2014, 32, 375-388. [CrossRef]

34. Shumyantseva, V.V.; Bulko, T.V.; Baychorov, I.H.; Archakov, A.I. Molecularly imprinted polymers (MIP) in electroanalysis of proteins. Biochem. Suppl. Ser. B Biomed. Chem. 2016, 10, 145-151. [CrossRef]

35. Liu, J.; Deng, Q.; Tao, D.; Yang, K.; Zhang, L.; Liang, Z.; Zhang, Y. Preparation of protein imprinted materials by hierarchical imprinting techniques and application in selective depletion of albumin from human serum. Sci. Rep. 2014, 4, 5487. [CrossRef]

36. Kuwata, T.; Uchida, A.; Takano, E.; Kitayama, Y.; Takeuchi, T. Molecularly Imprinted Polymer Arrays as Synthetic Protein Chips Prepared by Transcription-type Molecular Imprinting by Use of Protein-Immobilized Dots as Stamps. Anal. Chem. 2015, 87, 11784-11791. [CrossRef] [PubMed]

37. Rossetti, C.; Świtnicka-Plak, M.A.; Halvorsen, T.G.; Cormack, P.A.; Sellergren, B.; Reubsaet, L. Automated Protein Biomarker Analysis: Online extraction of clinical samples by Molecularly Imprinted Polymers. Sci. Rep. 2017, 7, srep44298. [CrossRef]

38. Demir, E.F.; Özçalışkan, E.; Karakaş, H.; Uygun, M.; Uygun, D.A.; Akgöl, S.; Denizli, A. Synthesis and characterization of albumin imprinted polymeric hydrogel membranes for proteomic studies. J. Biomater. Sci. Polym. Ed. 2018, 29, 2218-2236. [CrossRef]

39. Ji, J.; Zhou, Z.; Zhao, X.; Sun, J.; Sun, X. Electrochemical sensor based on molecularly imprinted film at Au nanoparticles-carbon nanotubes modified electrode for determination of cholesterol. Biosens. Bioelectron. 2014, 66, 590-595. [CrossRef]

40. Wang, F.-R.; Lee, G.-J.; Haridharan, N.; Wu, J.J. Electrochemical Sensor Using Molecular Imprinting Polymerization Modified Electrodes to Detect Methyl Parathion in Environmental Media. Electrocatalysis 2017, 9, 1-9. [CrossRef]

41. Zhang, B.; Lu, L.; Huang, F.; Lin, Z. $\left[\mathrm{Ru}(\mathrm{bpy})_{3}\right]^{2+}$-mediated photoelectrochemical detection of bisphenol A on a molecularly imprinted polypyrrole modified $\mathrm{SnO}_{2}$ electrode. Anal. Chim. Acta 2015, 887, 59-66. [CrossRef]

42. Zhang, J.; Niu, Y.; Li, S.; Luo, R.; Wang, C. A molecularly imprinted electrochemical sensor based on sol-gel technology and multiwalled carbon nanotubes-Nafion functional layer for determination of 2-nonylphenol in environmental samples. Sens. Actuators B Chem. 2014, 193, 844-850. [CrossRef]

43. Zheng, W.; Wu, H.; Jiang, Y.; Xu, J.; Li, X.; Zhang, W.; Qiu, F. A molecularly-imprinted-electrochemical-sensor modified with nano-carbon-dots with high sensitivity and selectivity for rapid determination of glucose. Anal. Biochem. 2018, 555, 42-49. [CrossRef] [PubMed]

44. Schreiber, T.; Weber, A.; Niedergall, K.; Riegler, J.; Bryniok, D.; Hirth, T.; Tovar, G.E.M. Water treatment by molecularly imprinted polymer nanoparticles. MRS Proc. 2009, 1169. [CrossRef]

45. Shen, X.; Xu, C.; Ye, L. Molecularly Imprinted Polymers for Clean Water: Analysis and Purification. Indian Eng. Chem. Res. 2012, 52, 13890-13899. [CrossRef]

46. Martínez, L.D.D.L.; Rodríguez-Aguilar, M.; Perez, R.O.; Gutiérrez-Hernández, J.M.; Díaz-Barriga, F.; Batres-Esquivel, L.; FloresRamírez, R. Synthesis and Evaluation of a Molecularly Imprinted Polymer for the Determination of Metronidazole in Water Samples. Bull. Environ. Contam. Toxicol. 2018, 100, 395-401. [CrossRef]

47. Dai, C.; Zhang, J.; Zhang, Y.; Zhou, X.; Liu, S. Application of Molecularly Imprinted Polymers to Selective Removal of Clofibric Acid from Water. PLoS ONE 2013, 8, e78167. [CrossRef] [PubMed]

48. Okutucu, B.; Sanlier, S.H. Decolorization of textile wastewater by dye-imprinted polymer. Desalin. Water Treat. 2015, 57, 21577-21584. [CrossRef]

49. Yusof, N.A.; Zakaria, N.D.; Maamor, N.A.M.; Abdullah, A.H.; Haron, J. Synthesis and Characterization of Molecularly Imprinted Polymer Membrane for the Removal of 2,4-Dinitrophenol. Int. J. Mol. Sci. 2013, 14, 3993-4004. [CrossRef]

50. Kashani, T.; Jahanshahi, M.; Rahimpour, A.; Peyravi, M. Nanopore Molecularly Imprinted Polymer Membranes for Environmental Usage: Selective Separation of 2,4-Dichlorophenoxyacetic Acid as a Toxic Herbicide from Water. Polym. Technol. Eng. 2016, 55, 1700-1712. [CrossRef]

51. Ghasemi, S.; Nematollahzadeh, A. Molecularly imprinted ultrafiltration polysulfone membrane with specific nano-cavities for selective separation and enrichment of paclitaxel from plant extract. React. Funct. Polym. 2018, 126, 9-19. [CrossRef]

52. Gao, B.; Li, Y.; Cui, K. Molecularly imprinted membrane with innovative structure and high performance for chiral separation of amino acids. Int. J. Polym. Mater. 2017, 67, 517-527. [CrossRef]

53. Ng, M.H.K.; Leo, C.P.; Abdullah, A.Z. Selective removal of dyes by molecular imprinted TiO2 nanoparticles in polysulfone ultrafiltration membrane. J. Environ. Chem. Eng. 2017, 5, 3991-3998. [CrossRef]

54. BelBruno, J.J. Molecularly Imprinted Polymers. Chem. Rev. 2018, 119, 94-119. [CrossRef] [PubMed] 
55. Wulff, G. The role of binding-site interactions in the molecular imprinting of polymers. Trends Biotechnol. 1993, 11, 85-87. [CrossRef]

56. Cormack, P.A.; Elorza, A.Z. Molecularly imprinted polymers: Synthesis and characterisation. J. Chromatogr. B 2004, 804, 173-182. [CrossRef]

57. Yemiş, F.; Alkan, P.; Yenigül, B.; Yenigül, M. Molecularly Imprinted Polymers and Their Synthesis by Different Methods. Polym. Polym. Compos. 2013, 21, 145-150. [CrossRef]

58. Lin, Z.; DeMarr, V.; Bao, J.; Wu, T. Molecularly Imprinted Polymer-Based Biosensors: For the Early, Rapid Detection of Pathogens, Biomarkers, and Toxins in Clinical, Environmental, or Food Samples. IEEE Nanotechnol. Mag. 2018, 12, 6-13. [CrossRef]

59. Yan, H.; Row, K.H. Characteristic and Synthetic Approach of Molecularly Imprinted Polymer. Int. J. Mol. Sci. 2006, 7, 155-178. [CrossRef]

60. Lee, S.H.; Doong, R.A. Design of Size-Tunable Molecularly Imprinted Polymer for Selective Adsorption of Pharmaceuticals and Biomolecules. J. Biosens. Bioelectron. 2016, 7, 4. [CrossRef]

61. Chen, L.; Wang, X.; Lu, W.; Wu, X.; Li, J. Molecular imprinting: Perspectives and applications. Chem. Soc. Rev. 2016, 45, $2137-2211$. [CrossRef]

62. Zaidi, S.A. Molecular imprinting polymers and their composites: A promising material for diverse applications. Biomater. Sci. 2017, 5, 388-402. [CrossRef]

63. Ramanavicius, S.; Ramanavicius, A. Conducting Polymers in the Design of Biosensors and Biofuel Cells. Polymers 2020, 13, 49. [CrossRef]

64. Blanco-López, M.; Lobo-Castañón, M.J.; Miranda-Ordieres, A.; Tuñón-Blanco, P. Electrochemical sensors based on molecularly imprinted polymers. Trends Anal. Chem. 2004, 23, 36-48. [CrossRef]

65. Heinze, J.; Frontana-Uribe, B.A.; Ludwigs, S. Electrochemistry of Conducting Polymers-Persistent Models and New Concepts. Chem. Rev. 2010, 110, 4724-4771. [CrossRef]

66. Ertürk, G.; Mattiasson, B. Molecular Imprinting Techniques Used for the Preparation of Biosensors. Sensors 2017, 17, 288. [CrossRef] [PubMed]

67. Rachkov, A.; Minoura, N. Towards molecularly imprinted polymers selective to peptides and proteins. The epitope approach. Biochim. Biophys. Acta Protein Struct. Mol. Enzym. 2001, 1544, 255-266. [CrossRef]

68. Justino, C.I.; Freitas, A.; Pereira, R.; Duarte, A.C.; Santos, T.A.R. Recent developments in recognition elements for chemical sensors and biosensors. Trends Anal. Chem. 2015, 68, 2-17. [CrossRef]

69. Algieri, C.; Drioli, E.; Guzzo, L.; Donato, L. Bio-Mimetic Sensors Based on Molecularly Imprinted Membranes. Sensors 2014, 14, 13863-13912. [CrossRef]

70. Sanjuán, A.M.; Ruiz, J.A.R.; García, F.C.; García, J.M. Recent developments in sensing devices based on polymeric systems. React. Funct. Polym. 2018, 133, 103-125. [CrossRef]

71. Dhanjai; Sinha, A.; Wu, L.; Lu, X.; Chen, J.; Jain, R. Advances in sensing and biosensing of bisphenols: A review. Anal. Chim. Acta 2018, 998, 1-27. [CrossRef]

72. Malinauskas, A. Electrochemical response of ascorbic acid at conducting and electrogenerated polymer modified electrodes for electroanalytical applications: A review. Talanta 2004, 64, 121-129. [CrossRef]

73. Rahmadhani, S.; Setiyanto, H.; Zulfikar, M.A. Electropolymerized of aniline as a new molecularly imprinted polymer for determination of phenol: A study for phenol sensor. In Proceedings of the 2017 International Seminar on Sensors, Instrumentation, Measurement and Metrology (ISSIMM), Surabaya, Indonesia, 25-26 August 2017; pp. 124-128. [CrossRef]

74. Nguyen, T.H.; Ansell, R.J. N-isopropylacrylamide as a functional monomer for noncovalent molecular imprinting. J. Mol. Recognit. 2011, 25, 1-10. [CrossRef] [PubMed]

75. Shumyantseva, V.V.; Bulko, T.V.; Suprun, E.V.; Kuzikov, A.V.; Agafonova, L.E.; Archakov, A.I. Electrochemical methods in biomedical studies. Biochem. Suppl. Ser. B Biomed. Chem. 2015, 9, 228-243. [CrossRef]

76. Li, X.; He, Y.; Zhao, F.; Zhang, W.; Ye, Z. Molecularly imprinted polymer-based sensors for atrazine detection by electropolymerization of o-phenylenediamine. RSC Adv. 2015, 5, 56534-56540. [CrossRef]

77. Mazzotta, E.; Turco, A.; Chianella, I.; Guerreiro, A.; Piletsky, S.A.; Malitesta, C. Solid-phase synthesis of electroactive nanoparticles of molecularly imprinted polymers. A novel platform for indirect electrochemical sensing applications. Sens. Actuators B Chem. 2016, 229, 174-180. [CrossRef]

78. Udomsap, D.; Brisset, H.; Culioli, G.; Dollet, P.; Laatikainen, K.; Siren, H.; Branger, C. Electrochemical molecularly imprinted polymers as material for pollutant detection. Mater. Today Commun. 2018, 17, 458-465. [CrossRef]

79. Rebocho, S.; Cordas, C.; Viveiros, R.; Casimiro, T. Development of a ferrocenyl-based MIP in supercritical carbon dioxide: Towards an electrochemical sensor for bisphenol A. J. Supercrit. Fluids 2018, 135, 98-104. [CrossRef]

80. Ekomo, V.M.; Branger, C.; Gavrila, A.-M.; Sarbu, A.; Koutsouras, D.A.; Stolz, C.; Malliaras, G.G.; Brisset, H. Electrochemical molecularly imprinted polymers in microelectrode devices. MRS Commun. 2020, 10, 324-331. [CrossRef]

81. Wang, H.; Li, W.; He, X.; Chen, L.; Zhang, Y. m-Aminophenylboronic acid as a functional monomer for fabricating molecularly imprinted polymer for the recognition of bovine serum albumin. React. Funct. Polym. 2008, 68, 1291-1296. [CrossRef]

82. Haupt, K. Peer Reviewed: Molecularly Imprinted Polymers: The Next Generation. Anal. Chem. 2003, 75, 376A-383A. [CrossRef]

83. Yuan, W.; Cai, Y.; Chen, Y.; Hong, X.; Liu, Z. Porous microsphere and its applications. Int. J. Nanomed. 2013, 8, 1111-1120. [CrossRef] 
84. Wackerlig, J.; Lieberzeit, P.A. Molecularly imprinted polymer nanoparticles in chemical sensing-Synthesis, characterisation and application. Sen. Actuators B Chem. 2015, 207, 144-157. [CrossRef]

85. He, J.; Tang, H.; You, L.; Yuan, L.; Liu, Z.; Zhu, J.; Lu, K.; Chen, X. Synthesis of Fragment-Imprinted Microspheres of 2,6Dichloropyrimidine as Templates and Determination of Sulfonamides in Milk Samples. Chromatographia 2013, 76, 959-965. [CrossRef]

86. Lv, Y.-K.; Zhao, C.-X.; Li, P.; He, Y.-D.; Yang, Z.-R.; Sun, H.-W. Preparation of doxycycline-imprinted magnetic microspheres by inverse-emulsion suspension polymerization for magnetic dispersion extraction of tetracyclines from milk samples. J. Sep. Sci. 2013, 36, 2656-2663. [CrossRef]

87. Su, X.; Li, X.; Li, J.; Liu, M.; Lei, F.; Tan, X.; Li, P.; Luo, W. Synthesis and characterization of core-shell magnetic molecularly imprinted polymers for solid-phase extraction and determination of Rhodamine B in food. Food Chem. 2014, 171, 292-297. [CrossRef] [PubMed]

88. Mayes, A.G.; Mosbach, K. Molecularly Imprinted Polymer Beads: Suspension Polymerization Using a Liquid Perfluorocarbon as the Dispersing Phase. Anal. Chem. 1996, 68, 3769-3774. [CrossRef] [PubMed]

89. Xia, Q.; Yun, Y.; Li, Q.; Huang, Z.; Liang, Z. Preparation and characterization of monodisperse molecularly imprinted polymer microspheres by precipitation polymerization for kaempferol. Des. Monomers Polym. 2016, 20, 201-209. [CrossRef]

90. Kitabatake, T.; Tabo, H.; Matsunaga, H.; Haginaka, J. Preparation of monodisperse curcumin-imprinted polymer by precipitation polymerization and its application for the extraction of curcuminoids from Curcuma longa L. Anal. Bioanal. Chem. 2013, 405, 6555-6561. [CrossRef]

91. Yu, Z.; Su, Q.; Tang, Y.; Xu, Z. Preparation and evaluation of aconitine imprinted microspheres and its application to body fluid samples. J. Appl. Polym. Sci. 2012, 128, 3425-3431. [CrossRef]

92. Zhao, C.; Dai, J.; Zhou, Z.; Dai, X.; Zou, Y.; Yu, P.; Zou, T.; Li, C.; Yan, Y. One-pot method for obtaining hydrophilic tetracyclineimprinted particles via precipitation polymerization in ethanol. J. Appl. Polym. Sci. 2013, 131, 1-11. [CrossRef]

93. Puoci, F.; Hampel, S.; Parisi, O.I.; Hassan, A.; Cirillo, G.; Picci, N. Imprinted microspheres doped with carbon nanotubes as novel electroresponsive drug-delivery systems. J. Appl. Polym. Sci. 2013, 130, 829-834. [CrossRef]

94. Zhou, T.; Shen, X.; Chaudhary, S.; Ye, L. Molecularly imprinted polymer beads prepared by pickering emulsion polymerization for steroid recognition. J. Appl. Polym. Sci. 2013, 131, 1-7. [CrossRef]

95. Hang, H.; Li, C.; Pan, J.; Li, L.; Dai, J.; Dai, X.; Yu, P.; Feng, Y. Selective separation of lambdacyhalothrin by porous/magnetic molecularly imprinted polymers prepared by Pickering emulsion polymerization. J. Sep. Sci. 2013, 36, 3285-3294. [CrossRef]

96. Zhou, T.; Kamra, T.; Ye, L. Preparation of diclofenac-imprinted polymer beads for selective molecular separation in water. J. Mol. Recognit. 2017, 31, e2608. [CrossRef] [PubMed]

97. Pan, J.; Li, L.; Hang, H.; Wu, R.; Dai, X.; Shi, W.; Yan, Y. Fabrication and Evaluation of Magnetic/Hollow Double-Shelled Imprinted Sorbents Formed by Pickering Emulsion Polymerization. Langmuir 2013, 29, 8170-8178. [CrossRef]

98. Li, X.-J.; Zhong, S.-A.; Li, C.-E. Synthesis of novel photoresponsive molecularly imprinted polymer microspheres with special binding properties. J. Appl. Polym. Sci. 2013, 130, 869-876. [CrossRef]

99. Zheng, X.-F.; Lian, Q.; Yang, H.; Wang, X. Surface Molecularly Imprinted Polymer of Chitosan Grafted Poly(methyl methacrylate) for 5-Fluorouracil and Controlled Release. Sci. Rep. 2016, 6, 21409. [CrossRef]

100. Zhang, Y.-J.; Feng, R.; Qi, N.; Zhang, Y.-P.; Bai, L.-Y.; Huang, M.-X. Synthesis and Evaluation of Cyromazine Molecularly Imprinted Polymeric Microspheres by Two-Step Seed Swelling Polymerization. Asian J. Chem. 2013, 25, 8329-8332. [CrossRef]

101. Chen, J.; Bai, L.; Zhang, Y.; Chen, N.; Zhang, Y. Fabrication of Atrazine Molecularly Imprinted Polymer Microsphere by Two Step Seed Swelling Polymerization Method. J. Chin. Chem. Soc. 2012, 59, 1493-1499. [CrossRef]

102. Qi, N.; Chen, J.; Zhang, Y.P.; Zhang, Y.J.; Bai, L.Y. Preparation of Melamine Molecularly Imprinted Polymeric Microspheres by Two-Step Seed Swelling Polymerization. Adv. Mater. Res. 2013, 668, 128-131. [CrossRef]

103. Zhang, Y.; Yao, X. Preparation of molecularly imprinted polymer for vanillin via seed swelling and suspension polymerization. Polym. Sci. Ser. B 2014, 56, 538-545. [CrossRef]

104. Wolska, J.; Bryjak, M. Removal of Bisphenol A from Aqueous Solution by Molecularly Imprinted Polymers. Sep. Sci. Technol. 2014, 49, 1643-1653. [CrossRef]

105. Shi, X.; Wu, A.; Zheng, S.; Li, R.; Zhang, D. Molecularly imprinted polymer microspheres for solid-phase extraction of chloramphenicol residues in foods. J. Chromatogr. B 2007, 850, 24-30. [CrossRef]

106. Brooks, B. Suspension Polymerization Processes. Chem. Eng. Technol. 2010, 33, 1737-1744. [CrossRef]

107. Nabavi, S.A.; Vladisavljević, G.T.; Eguagie, E.M.; Li, B.; Georgiadou, S.; Manović, V. Production of spherical mesoporous molecularly imprinted polymer particles containing tunable amine decorated nanocavities with $\mathrm{CO}_{2}$ molecule recognition properties. Chem. Eng. J. 2016, 306, 214-225. [CrossRef]

108. Qian, L.-W.; Hu, X.-L.; Guan, P.; Gao, B.; Wang, D.; Wang, C.-L.; Li, J.; Du, C.-B.; Song, W.-Q. Thermal preparation of lysozymeimprinted microspheres by using ionic liquid as a stabilizer. Anal. Bioanal. Chem. 2014, 406, 7221-7231. [CrossRef]

109. Zhang, Y.; Ding, J.; Gong, S. Preparation of molecularly imprinted polymers for vanillin via reversible addition-fragmentation chain transfer suspension polymerization. J. Appl. Polym. Sci. 2012, 128, 2927-2932. [CrossRef]

110. Suwanwong, Y.; Kulkeratiyut, S.; Prachayasittikul, V.; Boonpangrak, S. Effects of Polymerization Methods and Functional Monomers on Curcumin Imprinted Polymer Properties. Sep. Sci. Technol. 2014, 49, 1086-1095. [CrossRef] 
111. Sun, H.; Lai, J.-P.; Chen, F.; Zhu, D.-R. Molecularly imprinted microspheres synthesized by a simple, fast, and universal suspension polymerization for selective extraction of the topical anesthetic benzocaine in human serum and fish tissues. Anal. Bioanal. Chem. 2015, 407, 1745-1752. [CrossRef]

112. Moreno Bondi, M.C.; Urraca, J.L.; Carrasco, S.; Navarro-Villoslada, F. Preparation of Molecularly Imprinted Polymers. In Handbook of Molecularly Imprinted Polymers; Álvarez-Lorenzo, C., Concheiro, Á., Eds.; Smithers Rapra Technology Ltd.: Billingham, UK, 2013.

113. Li, G.L.; Möhwald, H.; Shchukin, D.G. Precipitation polymerization for fabrication of complex core-shell hybrid particles and hollow structures. Chem. Soc. Rev. 2013, 42, 3628-3646. [CrossRef]

114. Cacho, C.; Turiel, E.; Pérez-Conde, C. Molecularly imprinted polymers: An analytical tool for the determination of benzimidazole compounds in water samples. Talanta 2009, 78, 1029-1035. [CrossRef]

115. Pardeshi, S.; Dhodapkar, R.; Kumar, A. Molecularly imprinted microspheres and nanoparticles prepared using precipitation polymerisation method for selective extraction of gallic acid from Emblica officinalis. Food Chem. 2013, 146, 385-393. [CrossRef]

116. Ye, L.; Cormack, P.A.G.; Mosbach, K. Molecularly imprinted monodisperse microspheres for competitive radioassay. Anal. Commun. 1999, 36, 35-38. [CrossRef]

117. Liu, M.; Li, Y.; Han, J.; Dong, X. Synthesis of tetracycline-imprinted polymer microspheres by reversible addition-fragmentation chain-transfer precipitation polymerization using polyethylene glycol as a coporogen. J. Sep. Sci. 2014, 37, 1118-1125. [CrossRef]

118. Gao, F.-X.; Ma, X.-T.; He, X.-W.; Li, W.-Y.; Zhang, Y.-K. Smart surface imprinting polymer nanospheres for selective recognition and separation of glycoprotein. Colloids Surf. A Physicochem. Eng. Asp. 2013, 433, 191-199. [CrossRef]

119. Azodi-Deilami, S.; Abdouss, M.; Kordestani, D.; Shariatinia, Z. Preparation of N,N-p-phenylene bismethacryl amide as a novel cross-link agent for synthesis and characterization of the core-shell magnetic molecularly imprinted polymer nanoparticles. $J$. Mater. Sci. Mater. Electron. 2013, 25, 645-656. [CrossRef]

120. Yao, T.; Gu, X.; Li, T.; Li, J.; Li, J.; Zhao, Z.; Wang, J.; Qin, Y.; She, Y. Enhancement of surface plasmon resonance signals using a MIP/GNPs/rGO nano-hybrid film for the rapid detection of ractopamine. Biosens. Bioelectron. 2015, 75, 96-100. [CrossRef]

121. Tan, F.; Zhao, Q.; Teng, F.; Sun, D.; Gao, J.; Quan, X.; Chen, J. Molecularly imprinted polymer/mesoporous carbon nanoparticles as electrode sensing material for selective detection of ofloxacin. Mater. Lett. 2014, 129, 95-97. [CrossRef]

122. Sellergren, B.; Rückert, B.; Hall, A. Layer-by-Layer Grafting of Molecularly Imprinted Polymers via Iniferter Modified Supports. Adv. Mater. 2002, 14, 1204-1208. [CrossRef]

123. Rückert, B.; Hall, A.J.; Sellergren, B. Molecularly imprinted composite materials via iniferter-modified supports. J. Mater. Chem. 2002, 12, 2275-2280. [CrossRef]

124. Barahona, F.; Turiel, E.; Cormack, P.A.G.; Martín-Esteban, A. Chromatographic performance of molecularly imprinted polymers: Core-shell microspheres by precipitation polymerization and grafted MIP films via iniferter-modified silica beads. J. Polym. Sci. Part A Polym. Chem. 2010, 48, 1058-1066. [CrossRef]

125. Minko, S. Grafting on Solid Surfaces: “Grafting to" and "Grafting from" Methods. In Polymer Surfaces and Interfaces: Characterization, Modification and Applications; Stamm, M., Ed.; Springer: Berlin/Heidelberg, Germany, 2008; pp. 215-234.

126. Chern, C. Emulsion polymerization mechanisms and kinetics. Prog. Polym. Sci. 2006, 31, 443-486. [CrossRef]

127. Yamak, H.B. Emulsion Polymerization: Effects of Polymerization Variables on the Properties of Vinyl Acetate Based Emulsion Polymers. In Polymer Science; Yilmaz, F., Ed.; InTech: London, UK, 2013.

128. Matsui, J.; Kato, T.; Takeuchi, T.; Suzuki, M.; Yokoyama, K.; Tamiya, E.; Karube, I. Molecular recognition in continuous polymer rods prepared by a molecular imprinting technique. Anal. Chem. 1993, 65, 2223-2224. [CrossRef]

129. Matsui, J.; Miyoshi, Y.; Matsui, R.; Takeuchi, T. Rod-Type Affinity Media for Liquid Chromatography Prepared by in-situMolecular Imprinting. Anal. Sci. 1995, 11, 1017-1019. [CrossRef]

130. MacDougall, D.; Francis, J.A.; Cox, G.V.; Grosby, D.G.; Estes, F.L.; Freeman, D.H.; Gibbs, W.E.; Gordon, G.E.; Keith, L.H.; Lal, J.; et al. Guidelines for data acquisition and data quality evaluation in environmental chemistry. Anal. Chem. 1980, 52, $2242-2249$. [CrossRef]

131. Alvarez-Lorenzo, C. Handbook of Molecularly Imprinted Polymers; Smithers Information Ltd.: Akron, OH, USA, 2013.

132. Liu, C.-C. Electrochemical Sensors. In The Biomedical Engineering Handbook Medical Devices and Systems, 3rd ed.; Bronzino, J.D., Ed.; CRC Press Taylor \& Francis Group: Boca Raton, FL, USA, 2006.

133. Jolly, P.; Tamboli, V.; Harniman, R.L.; Estrela, P.; Allender, C.J.; Bowen, J.L. Aptamer-MIP hybrid receptor for highly sensitive electrochemical detection of prostate specific antigen. Biosens. Bioelectron. 2016, 75, 188-195. [CrossRef]

134. Bakas, I.; Hayat, A.; Piletsky, S.; Piletska, E.; Chehimi, M.M.; Noguer, T.; Rouillon, R. Electrochemical impedimetric sensor based on molecularly imprinted polymers/sol-gel chemistry for methidathion organophosphorous insecticide recognition. Talanta 2014, 130, 294-298. [CrossRef]

135. Zhang, W.; Xiong, H.; Chen, M.; Zhang, X.; Wang, S. Surface-enhanced molecularly imprinted electrochemiluminescence sensor based on Ru@SiO 2 for ultrasensitive detection of fumonisin B1. Biosens. Bioelectron. 2017, 96, 55-61. [CrossRef]

136. Graniczkowska, K.; Pütz, M.; Hauser, F.M.; De Saeger, S.; Beloglazova, N.V. Capacitive sensing of N-formylamphetamine based on immobilized molecular imprinted polymers. Biosens. Bioelectron. 2017, 92, 741-747. [CrossRef]

137. Lenain, P.; de Saeger, S.; Mattiasson, B.; Hedström, M. Affinity sensor based on immobilized molecular imprinted synthetic recognition elements. Biosens. Bioelectron. 2015, 69, 34-39. [CrossRef] 
138. Warwick, C.; Guerreiro, A.; Gomez-Caballero, A.; Wood, E.; Kitson, J.; Robinson, J.; Soares, A. Conductance based sensing and analysis of soluble phosphates in wastewater. Biosens. Bioelectron. 2013, 52, 173-179. [CrossRef]

139. Rosy; Chasta, H.; Goyal, R.N. Molecularly imprinted sensor based on o-aminophenol for the selective determination of norepinephrine in pharmaceutical and biological samples. Talanta 2014, 125, 167-173. [CrossRef]

140. Uygun, Z.O.; Dilgin, Y. A novel impedimetric sensor based on molecularly imprinted polypyrrole modified pencil graphite electrode for trace level determination of chlorpyrifos. Sens. Actuators B Chem. 2013, 188, 78-84. [CrossRef]

141. Ratautaite, V.; Janssens, S.; Haenen, K.; Nesládek, M.; Ramanaviciene, A.; Baleviciute, I.; Ramanavicius, A. Molecularly Imprinted Polypyrrole Based Impedimentric Sensor for Theophylline Determination. Electrochim. Acta 2014, 130, 361-367. [CrossRef]

142. Gurtova, O.; Ye, L.; Chmilenko, F. Potentiometric propranolol-selective sensor based on molecularly imprinted polymer. Anal. Bioanal. Chem. 2012, 405, 287-295. [CrossRef]

143. Bagheri, H.; Shirzadmehr, A.; Rezaei, M. Designing and fabrication of new molecularly imprinted polymer-based potentiometric nano-graphene/ionic liquid/carbon paste electrode for the determination of losartan. J. Mol. Liq. 2015, 212, 96-102. [CrossRef]

144. Basozabal, I.; Guerreiro, A.; Gomez-Caballero, A.; Goicolea, M.A.; Barrio, R.J. Direct potentiometric quantification of histamine using solid-phase imprinted nanoparticles as recognition elements. Biosens. Bioelectron. 2014, 58, 138-144. [CrossRef] [PubMed]

145. Anirudhan, T.S.; Alexander, S. Design and fabrication of molecularly imprinted polymer-based potentiometric sensor from the surface modified multiwalled carbon nanotube for the determination of lindane ( $\gamma$-hexachlorocyclohexane), an organochlorine pesticide. Biosens. Bioelectron. 2015, 64, 586-593. [CrossRef]

146. Rizk, M.; Toubar, S.S.; Sayour, H.E.E.-D.; Mohamed, D.; Touny, R.M. A new potentiometric sensor based on molecularly imprinted polymer for analysis of a veterinary drug imidocarb dipropionate. Eur. J. Chem. 2014, 5, 18-23. [CrossRef]

147. Li, L.; Liang, Y.; Liu, Y. Designing of molecularly imprinted polymer-based potentiometric sensor for the determination of heparin. Anal. Biochem. 2013, 434, 242-246. [CrossRef]

148. Kou, L.-J.; Liang, R.-N.; Wang, X.-W.; Chen, Y.; Qin, W. Potentiometric sensor for determination of neutral bisphenol A using a molecularly imprinted polymer as a receptor. Anal. Bioanal. Chem. 2013, 405, 4931-4936. [CrossRef]

149. Zarezadeh, A.; Rajabi, H.R.; Sheydaei, O.; Khajehsharifi, H. Application of a nano-structured molecularly imprinted polymer as an efficient modifier for the design of captopril drug selective sensor: Mechanism study and quantitative determination. Mater. Sci. Eng. C 2018, 94, 879-885. [CrossRef]

150. Mamo, S.K.; Gonzalez-Rodriguez, J. Development of a Molecularly Imprinted Polymer-Based Sensor for the Electrochemical Determination of Triacetone Triperoxide (TATP). Sensors 2014, 14, 23269-23282. [CrossRef]

151. Liu, B.; Xiao, B.; Cui, L.; Wang, M. Molecularly imprinted electrochemical sensor for the highly selective and sensitive determination of melamine. Mater. Sci. Eng. C 2015, 55, 457-461. [CrossRef]

152. Tan, X.; Hu, Q.; Wu, J.; Li, X.; Li, P.; Yu, H.; Li, X.; Lei, F. Electrochemical sensor based on molecularly imprinted polymer reduced graphene oxide and gold nanoparticles modified electrode for detection of carbofuran. Sens. Actuators B Chem. 2015, $220,216-221$. [CrossRef]

153. Zhao, L.; Zeng, B.; Zhao, F. Electrochemical determination of tartrazine using a molecularly imprinted polymer-Multiwalled carbon nanotubes-Ionic liquid supported Pt nanoparticles composite film coated electrode. Electrochim. Acta 2014, 146, 611-617. [CrossRef]

154. Pacheco, J.; Castro, M.; Machado, S.; Barroso, M.F.; Nouws, H.; Delerue-Matos, C. Molecularly imprinted electrochemical sensor for ochratoxin A detection in food samples. Sens. Actuators B Chem. 2015, 215, 107-112. [CrossRef]

155. Nezhadali, A.; Mojarrab, M. Fabrication of an electrochemical molecularly imprinted polymer triamterene sensor based on multivariate optimization using multi-walled carbon nanotubes. J. Electroanal. Chem. 2015, 744, 85-94. [CrossRef]

156. Lei, R.; Guo, C.; Xiong, H.; Dong, C.; Zhang, X.; Wang, S. A Novel Electrochemical Sensor for $\beta 2$-Agonists with High Sensitivity and Selectivity Based on Surface Molecularly Imprinted Sol-gel Doped with Antimony-Doped Tin Oxide. Electroanalysis 2014, 26, 1004-1012. [CrossRef]

157. Gholivand, M.; Torkashvand, M. The fabrication of a new electrochemical sensor based on electropolymerization of nanocomposite gold nanoparticle-molecularly imprinted polymer for determination of valganciclovir. Mater. Sci. Eng. C 2016, 59, 594-603. [CrossRef]

158. Li, Y.; Song, H.; Zhang, L.; Zuo, P.; Ye, B.-C.; Yao, J.; Chen, W. Supportless electrochemical sensor based on molecularly imprinted polymer modified nanoporous microrod for determination of dopamine at trace level. Biosens. Bioelectron. 2016, 78, 308-314. [CrossRef] [PubMed]

159. Yang, G.; Zhao, F. Electrochemical sensor for dimetridazole based on novel gold nanoparticles@molecularly imprinted polymer. Sens. Actuators B Chem. 2015, 220, 1017-1022. [CrossRef]

160. Dadkhah, S.; Ziaei, E.; Mehdinia, A.; Kayyal, T.B.; Jabbari, A. A glassy carbon electrode modified with amino-functionalized graphene oxide and molecularly imprinted polymer for electrochemical sensing of bisphenol A. Microchim. Acta 2016, 183, 1933-1941. [CrossRef]

161. Silva, H.; Pacheco, J.; Silva, J.; Viswanathan, S.; Delerue-Matos, C. Molecularly imprinted sensor for voltammetric detection of norfloxacin. Sens. Actuators B Chem. 2015, 219, 301-307. [CrossRef]

162. Zhao, Y.; Yuan, F.; Quan, X.; Yu, H.; Chen, S.; Zhao, H.; Liu, Z.; Hilal, N. An electrochemical sensor for selective determination of sulfamethoxazole in surface water using a molecularly imprinted polymer modified BDD electrode. Anal. Methods 2015, 7, 2693-2698. [CrossRef] 
163. Kumar, N.; Rosy; Goyal, R.N. A melamine based molecularly imprinted sensor for the determination of 8-hydroxydeoxyguanosine in human urine. Talanta 2017, 166, 215-222. [CrossRef]

164. Toro, M.J.U.; Marestoni, L.D.; Sotomayor, M.D.P.T. A new biomimetic sensor based on molecularly imprinted polymers for highly sensitive and selective determination of hexazinone herbicide. Sens. Actuators B Chem. 2015, 208, 299-306. [CrossRef]

165. Rao, H.; Chen, M.; Ge, H.; Lu, Z.; Liu, X.; Zou, P.; Wang, X.; He, H.; Zeng, X.; Wang, Y. A novel electrochemical sensor based on Au@PANI composites film modified glassy carbon electrode binding molecular imprinting technique for the determination of melamine. Biosens. Bioelectron. 2016, 87, 1029-1035. [CrossRef]

166. Cai, R.; Rao, W.; Zhang, Z.; Long, F.; Yin, Y. An imprinted electrochemical sensor for bisphenol A determination based on electrodeposition of a graphene and Ag nanoparticle modified carbon electrode. Anal. Methods 2014, 6, 1590-1597. [CrossRef]

167. Akhoundian, M.; Rüter, A.; Shinde, S. Ultratrace Detection of Histamine Using a Molecularly-Imprinted Polymer-Based Voltammetric Sensor. Sensors 2017, 17, 645. [CrossRef]

168. Prasad, B.B.; Singh, K. An electroconducting copper (II) imprinted sensor using algae as cheap substitute of multiwalled carbon nanotubes. Electrochim. Acta 2016, 187, 193-203. [CrossRef]

169. Tan, Y.; Jin, J.; Zhang, S.; Shi, Z.; Wang, J.; Zhang, J.; Pu, W.; Yang, C. Electrochemical Determination of Bisphenol A Using a Molecularly Imprinted Chitosan-acetylene Black Composite Film Modified Glassy Carbon Electrode. Electroanalysis 2015, 28, 189-196. [CrossRef]

170. Deng, P.; Xu, Z.; Kuang, Y. Electrochemical determination of bisphenol A in plastic bottled drinking water and canned beverages using a molecularly imprinted chitosan-graphene composite film modified electrode. Food Chem. 2014, 157, 490-497. [CrossRef] [PubMed]

171. Motia, S.; Tudor, I.A.; Popescu, L.M.C.; Piticescu, R.M.; Bouchikhi, B.; El Bari, N. Development of a novel electrochemical sensor based on electropolymerized molecularly imprinted polymer for selective detection of sodium lauryl sulfate in environmental waters and cosmetic products. J. Electroanal. Chem. 2018, 823, 553-562. [CrossRef]

172. Li, Y.; Liu, J.; Zhang, Y.; Gu, M.; Wang, D.; Dang, Y.-Y.; Ye, B.-C.; Li, Y. A robust electrochemical sensing platform using carbon paste electrode modified with molecularly imprinted microsphere and its application on methyl parathion detection. Biosens. Bioelectron. 2018, 106, 71-77. [CrossRef] [PubMed]

173. Gu, Y.; Yan, X.; Li, C.; Zheng, B.; Li, Y.; Liu, W.; Zhang, Z.; Yang, M. Biomimetic sensor based on molecularly imprinted polymer with nitroreductase-like activity for metronidazole detection. Biosens. Bioelectron. 2015, 77, 393-399. [CrossRef] [PubMed]

174. Chen, H.-J.; Zhang, Z.-H.; Cai, R.; Kong, X.-Q.; Chen, X.; Liu, Y.-N.; Yao, S.-Z. Molecularly imprinted electrochemical sensor based on a reduced graphene modified carbon electrode for tetrabromobisphenol A detection. Analyst 2013, 138, 2769-2776. [CrossRef]

175. Chen, H.; Zhang, Z.; Cai, R.; Rao, W.; Long, F. Molecularly imprinted electrochemical sensor based on nickel nanoparticlesgraphene nanocomposites modified electrode for determination of tetrabromobisphenol A. Electrochim. Acta 2014, 117, 385-392. [CrossRef]

176. Zhang, Z.; Cai, R.; Long, F.; Wang, J. Development and application of tetrabromobisphenol A imprinted electrochemical sensor based on graphene/carbon nanotubes three-dimensional nanocomposites modified carbon electrode. Talanta 2015, 134, 435-442. [CrossRef]

177. Li, J.; Xu, Z.; Liu, M.; Deng, P.; Tang, S.; Jiang, J.; Feng, H.; Qian, D.; He, L. Ag/N-doped reduced graphene oxide incorporated with molecularly imprinted polymer: An advanced electrochemical sensing platform for salbutamol determination. Biosens. Bioelectron. 2017, 90, 210-216. [CrossRef]

178. Hassan, A.H.; Moura, S.L.; Ali, F.; Moselhy, W.A.; Sotomayor, M.; Pividori, M.I. Electrochemical sensing of methyl parathion on magnetic molecularly imprinted polymer. Biosens. Bioelectron. 2018, 118, 181-187. [CrossRef]

179. Anirudhan, T.; Athira, V.; Sekhar, V.C. Electrochemical sensing and nano molar level detection of Bisphenol-A with molecularly imprinted polymer tailored on multiwalled carbon nanotubes. Polymer 2018, 146, 312-320. [CrossRef]

180. Nezhadali, A.; Bonakdar, G.A. Multivariate optimization of mebeverine analysis using molecularly imprinted polymer electrochemical sensor based on silver nanoparticles. J. Food Drug Anal. 2018, 27, 305-314. [CrossRef]

181. Tan, F.; Cong, L.; Li, X.; Zhao, Q.; Zhao, H.; Quan, X.; Chen, J. An electrochemical sensor based on molecularly imprinted polypyrrole/graphene quantum dots composite for detection of bisphenol A in water samples. Sens. Actuators B Chem. 2016, 233, 599-606. [CrossRef]

182. Karimian, N.; Zavar, M.H.A.; Chamsaz, M.; Turner, A.; Tiwari, A. On/off-switchable electrochemical folic acid sensor based on molecularly imprinted polymer electrode. Electrochem. Commun. 2013, 36, 92-95. [CrossRef]

183. Chen, Z.; Tang, C.; Zeng, Y.; Liu, H.; Yin, Z.; Li, L. Determination of Bisphenol a Using an Electrochemical Sensor Based on a Molecularly Imprinted Polymer-Modified Multiwalled Carbon Nanotube Paste Electrode. Anal. Lett. 2014, 47, 996-1014. [CrossRef]

184. Saksena, K.; Shrivastava, A.; Kant, R. Chiral analysis of ascorbic acid in bovine serum using ultrathin molecular imprinted polyaniline/graphite electrode. J. Electroanal. Chem. 2017, 795, 103-109. [CrossRef]

185. Deng, P.; Xu, Z.; Li, J.; Kuang, Y. Acetylene black paste electrode modified with a molecularly imprinted chitosan film for the detection of bisphenol A. Microchim. Acta 2013, 180, 861-869. [CrossRef]

186. Nie, D.; Han, Z.; Yu, Y.; Shi, G. Composites of multiwalled carbon nanotubes/polyethyleneimine (MWCNTs/PEI) and molecularly imprinted polymers for dinitrotoluene recognition. Sens. Actuators B Chem. 2016, 224, 584-591. [CrossRef] 
187. Huang, X.; Wei, S.; Yao, S.; Zhang, H.; He, C.; Cao, J. Development of molecularly imprinted electrochemical sensor with reduced graphene oxide and titanium dioxide enhanced performance for the detection of toltrazuril in chicken muscle and egg. J. Pharm. Biomed. Anal. 2018, 164, 607-614. [CrossRef] [PubMed]

188. Jaiswal, S.; Singh, R.; Singh, K.; Fatma, S.; Prasad, B.B. Enantioselective analysis of D- and l- Serine on a layer-by-layer imprinted electrochemical sensor. Biosens. Bioelectron. 2018, 124-125, 176-183. [CrossRef]

189. Yola, M.L.; Atar, N. Development of cardiac troponin-I biosensor based on boron nitride quantum dots including molecularly imprinted polymer. Biosens. Bioelectron. 2018, 126, 418-424. [CrossRef]

190. Sun, Y.; Xu, L.; Waterhouse, G.I.; Wang, M.; Qiao, X.; Xu, Z. Novel three-dimensional electrochemical sensor with dual signal amplification based on MoS2 nanosheets and high-conductive NH2-MWCNT@COF for sulfamerazine determination. Sens. Actuators B Chem. 2018, 281, 107-114. [CrossRef]

191. Alizadeh, T.; Atashi, F.; Ganjali, M.R. Molecularly imprinted polymer nano-sphere/multi-walled carbon nanotube coated glassy carbon electrode as an ultra-sensitive voltammetric sensor for picomolar level determination of RDX. Talanta 2018, 194, 415-421. [CrossRef]

192. Yu, R.; Zhou, H.; Li, M.; Song, Q. Rational selection of the monomer for molecularly imprinted polymer preparation for selective and sensitive detection of 3-methylindole in water. J. Electroanal. Chem. 2018, 832, 129-136. [CrossRef]

193. Liu, Y.; Liang, Y.; Yang, R.; Li, J.; Qu, L. A highly sensitive and selective electrochemical sensor based on polydopamine functionalized graphene and molecularly imprinted polymer for the 2,4-dichlorophenol recognition and detection. Talanta 2018, 195, 691-698. [CrossRef]

194. Li, H.-H.; Wang, H.-H.; Li, W.-T.; Fang, X.-X.; Guo, X.-C.; Zhou, W.-H.; Cao, X.; Kou, D.-X.; Zhou, Z.-J.; Wu, S.-X. A novel electrochemical sensor for epinephrine based on three dimensional molecularly imprinted polymer arrays. Sens. Actuators $B$ Chem. 2016, 222, 1127-1133. [CrossRef]

195. Singh, A.K.; Singh, M. QCM sensing of melphalan via electropolymerized molecularly imprinted polythiophene films. Biosens. Bioelectron. 2015, 74, 711-717. [CrossRef] [PubMed]

196. Moreira, F.; Sharma, S.; Dutra, R.A.; Noronha, J.P.; Cass, A.E.; Sales, M.G.F. Protein-responsive polymers for point-of-care detection of cardiac biomarker. Sens. Actuators B Chem. 2014, 196, 123-132. [CrossRef]

197. Cardoso, A.R.; Marques, A.C.; Santos, L.; Carvalho, A.; Costa, F.M.; Martins, R.; Sales, M.G.F.; Fortunato, E. Molecularly-imprinted chloramphenicol sensor with laser-induced graphene electrodes. Biosens. Bioelectron. 2018, 124-125, 167-175. [CrossRef] [PubMed]

198. Xue, C.; Han, Q.; Wang, Y.; Wu, J.; Wen, T.; Wang, R.; Hong, J.; Zhou, X.; Jiang, H. Amperometric detection of dopamine in human serumby electrochemical sensor based on gold nanoparticles doped molecularly imprinted polymers. Biosens. Bioelectron. 2013, 49, 199-203. [CrossRef]

199. Yarman, A.; Scheller, F.W. The First Electrochemical MIP Sensor for Tamoxifen. Sensors 2014, 14, 7647-7654. [CrossRef]

200. Wang, Z.; Li, J.; Liu, X.; Yang, J.; Lu, X. Preparation of an amperometric sensor for norfloxacin based on molecularly imprinted grafting photopolymerization. Anal. Bioanal. Chem. 2013, 405, 2525-2533. [CrossRef]

201. Azevedo, S.D.; Lakshmi, D.; Chianella, I.; Whitcombe, M.; Karim, K.; Ivanova-Mitseva, P.K.; Subrahmanyam, S.; Piletsky, S. Molecularly Imprinted Polymer-Hybrid Electrochemical Sensor for the Detection of $\beta$-Estradiol. Indian Eng. Chem. Res. 2013, 52, 13917-13923. [CrossRef]

202. Zhao, H.; Wang, H.; Quan, X.; Tan, F. Amperometric Sensor for Tetracycline Determination Based on Molecularly Imprinted Technique. Proced. Environ. Sci. 2013, 18, 249-257. [CrossRef]

203. Ramanaviciene, A.; Ramanavicius, A. Molecularly imprinted polypyrrole-based synthetic receptor for direct detection of bovine leukemia virus glycoproteins. Biosens. Bioelectron. 2004, 20, 1076-1082. [CrossRef]

204. Ratautaite, V.; Topkaya, S.N.; Mikoliunaite, L.; Ozsoz, M.; Oztekin, Y.; Ramanaviciene, A.; Ramanavicius, A. Molecularly Imprinted Polypyrrole for DNA Determination. Electroanalysis 2013, 25, 1169-1177. [CrossRef]

205. Hirsch, R.; Ternes, T.; Haberer, K.; Kratz, K.-L. Occurrence of antibiotics in the aquatic environment. Sci. Total. Environ. 1999, 225, 109-118. [CrossRef]

206. Al Qarni, H.; Collier, P.; O'Keeffe, J.; Akunna, J. Investigating the removal of some pharmaceutical compounds in hospital wastewater treatment plants operating in Saudi Arabia. Environ. Sci. Pollut. Res. 2016, 23, 13003-13014. [CrossRef] [PubMed]

207. A Ternes, T.; Stüber, J.; Herrmann, N.; McDowell, D.; Ried, A.; Kampmann, M.; Teiser, B. Ozonation: A tool for removal of pharmaceuticals, contrast media and musk fragrances from wastewater? Water Res. 2003, 37, 1976-1982. [CrossRef]

208. Crapnell, R.D.; Dempsey-Hibbert, N.C.; Peeters, M.; Tridente, A.; Banks, C.E. Molecularly imprinted polymer based electrochemical biosensors: Overcoming the challenges of detecting vital biomarkers and speeding up diagnosis. Talanta Open 2020, 2, 100018. [CrossRef]

209. Dietl, S.; Sobek, H.; Mizaikoff, B. Epitope-imprinted polymers for biomacromolecules: Recent strategies, future challenges and selected applications. TrAC Trends Anal. Chem. 2021, 143, 116414. [CrossRef]

210. Al-Kindy, S.; Badía, R.; Suárez-Rodríguez, J.L.; Díaz-García, M.E. Molecularly Imprinted Polymers and Optical Sensing Applications. Crit. Rev. Anal. Chem. 2000, 30, 291-309. [CrossRef]

211. Henry, O.Y.F.; Cullen, D.; Piletsky, S.A. Optical interrogation of molecularly imprinted polymers and development of MIP sensors: A review. Anal. Bioanal. Chem. 2005, 382, 947-956. [CrossRef] [PubMed]

212. Zhao, B.; Feng, S.; Hu, Y.; Wang, S.; Lu, X. Rapid determination of atrazine in apple juice using molecularly imprinted polymers coupled with gold nanoparticles-colorimetric/SERS dual chemosensor. Food Chem. 2018, 276, 366-375. [CrossRef] [PubMed] 
213. Wang, P.; Ge, L.; Li, M.; Li, W.; Li, L.; Wang, Y.; Yu, J. Photoelectrochemical Sensor Based on Molecularly Imprinted PolymerCoated TiO2 Nanotubes for Lindane Specific Recognition and Detection. J. Inorg. Organomet. Polym. Mater. 2013, $23,703-711$. [CrossRef]

214. Kong, Q.; Wang, Y.; Zhang, L.; Ge, S.; Yu, J. A novel microfluidic paper-based colorimetric sensor based on molecularly imprinted polymer membranes for highly selective and sensitive detection of bisphenol A. Sens. Actuators B Chem. 2017, 243, 130-136. [CrossRef]

215. Sergeyeva, T.; Chelyadina, D.S.; Gorbach, L.A.; Brovko, O.O.; Piletska, E.V.; Piletsky, S.; Sergeeva, L.M.; El'Skaya, A.V. Colorimetric biomimetic sensor systems based on molecularly imprinted polymer membranes for highly-selective detection of phenol in environmental samples. Biopolym. Cell 2014, 30, 209-215. [CrossRef]

216. Huang, K.; Chen, Y.; Zhou, F.; Zhao, X.; Liu, J.; Mei, S.; Zhou, Y.; Jing, T. Integrated ion imprinted polymers-paper composites for selective and sensitive detection of Cd(II) ions. J. Hazard. Mater. 2017, 333, 137-143. [CrossRef]

217. Foguel, M.V.; Ton, X.-A.; Zanoni, M.V.; Sotomayor, M.; Haupt, K.; Bui, B.T.S. A molecularly imprinted polymer-based evanescent wave fiber optic sensor for the detection of basic red 9 dye. Sens. Actuators B Chem. 2015, 218, 222-228. [CrossRef]

218. Liu, X.; Yu, D.; Yu, Y.; Ji, S. Preparation of a magnetic molecularly imprinted polymer for selective recognition of rhodamine B. Appl. Surf. Sci. 2014, 320, 138-145. [CrossRef]

219. Yan, K.; Yang, Y.; Zhang, J. A self-powered sensor based on molecularly imprinted polymer-coupled graphitic carbon nitride photoanode for selective detection of bisphenol A. Sens. Actuators B Chem. 2018, 259, 394-401. [CrossRef]

220. Dai, J.; Vu, D.; Nagel, S.; Lin, C.-H.; De Cortalezzi, M.F. Colloidal crystal templated molecular imprinted polymer for the detection of 2-butoxyethanol in water contaminated by hydraulic fracturing. Microchim. Acta 2017, 185, 32. [CrossRef] [PubMed]

221. Kadhem, A.J.; Xiang, S.; Nagel, S.; Lin, C.-H.; de Cortalezzi, M.F. Photonic Molecularly Imprinted Polymer Film for the Detection of Testosterone in Aqueous Samples. Polymers 2018, 10, 349. [CrossRef]

222. Du, Q.; Zhang, Y.; Yu, L.; He, H. Surface molecularly imprinted polymers fabricated by differential UV-vis spectra and reverse prediction method for the enrichment and determination of sterigmatocystin. Food Chem. 2021, 367, 130715. [CrossRef]

223. Tan, L.; Chen, K.; Huang, C.; Peng, R.; Luo, X.; Yang, R.; Cheng, Y.; Tang, Y. A fluorescent turn-on detection scheme for $\alpha-$ fetoprotein using quantum dots placed in a boronate-modified molecularly imprinted polymer with high affinity for glycoproteins. Microchim. Acta 2015, 182, 2615-2622. [CrossRef]

224. Xu, L.; Fang, G.; Pan, M.; Wang, X.; Wang, S. One-pot synthesis of carbon dots-embedded molecularly imprinted polymer for specific recognition of sterigmatocystin in grains. Biosens. Bioelectron. 2016, 77, 950-956. [CrossRef]

225. Ren, X.; Chen, L. Preparation of molecularly imprinted polymer coated quantum dots to detect nicosulfuron in water samples Anal. Bioanal. Chem. 2015, 407, 8087-8095. [CrossRef]

226. Xiong, Y.; Ye, Z.; Xu, J.; Liu, Y.; Zhang, H. A microvolume molecularly imprinted polymer modified fiber-optic evanescent wave sensor for bisphenol A determination. Anal. Bioanal. Chem. 2014, 406, 2411-2420. [CrossRef]

227. Wang, J.; Cheng, R.; Wang, Y.; Sun, L.; Chen, L.; Dai, X.; Pan, J.; Pan, G.; Yan, Y. Surface-imprinted fluorescence microspheres as ultrasensitive sensor for rapid and effective detection of tetracycline in real biological samples. Sens. Actuators B Chem. 2018, 263, 533-542. [CrossRef]

228. Lu, X.; Yang, Y.; Zeng, Y.; Li, L.; Wu, X. Rapid and reliable determination of p-nitroaniline in wastewater by molecularly imprinted fluorescent polymeric ionic liquid microspheres. Biosens. Bioelectron. 2018, 99, 47-55. [CrossRef]

229. Wei, X.; Xu, G.; Gong, C.; Qin, F.; Gong, X.; Li, C. Fabrication and evaluation of sulfanilamide-imprinted composite sensors by developing a custom-tailored strategy. Sens. Actuators B Chem. 2018, 255, 2697-2703. [CrossRef]

230. Wei, X.; Hao, T.; Xu, Y.; Lu, K.; Li, H.; Yan, Y.; Zhou, Z. Facile polymerizable surfactant inspired synthesis of fluorescent molecularly imprinted composite sensor via aqueous CdTe quantum dots for highly selective detection of $\lambda$-cyhalothrin. Sens. Actuators B Chem. 2016, 224, 315-324. [CrossRef]

231. Wagner, S.; Bell, J.; Biyikal, M.; Gawlitza, K.; Rurack, K. Integrating fluorescent molecularly imprinted polymer (MIP) sensor particles with a modular microfluidic platform for nanomolar small-molecule detection directly in aqueous samples. Biosens. Bioelectron. 2018, 99, 244-250. [CrossRef]

232. Xu, S.; Lu, H. Mesoporous structured MIPs@CDs fluorescence sensor for highly sensitive detection of TNT. Biosens. Bioelectron. 2016, 85, 950-956. [CrossRef] [PubMed]

233. Wang, J.; Qiu, H.; Shen, H.; Pan, J.; Dai, X.; Yan, Y.; Pan, G.; Sellergren, B. Molecularly imprinted fluorescent hollow nanoparticles as sensors for rapid and efficient detection $\lambda$-cyhalothrin in environmental water. Biosens. Bioelectron. 2016, 85, 387-394. [CrossRef] [PubMed]

234. Li, H.; Li, N.; Jiang, J.; Chen, D.; Xu, Q.; Li, H.; He, J.; Lu, J. Molecularly imprinted magnetic microparticles for the simultaneous detection and extraction of Rhodamine B. Sens. Actuators B Chem. 2017, 246, 286-292. [CrossRef]

235. Amjadi, M.; Jalili, R. Molecularly imprinted mesoporous silica embedded with carbon dots and semiconductor quantum dots as a ratiometric fluorescent sensor for diniconazole. Biosens. Bioelectron. 2017, 96, 121-126. [CrossRef] [PubMed]

236. Wu, X.; Zhang, Z.; Li, J.; You, H.; Li, Y.; Chen, L. Molecularly imprinted polymers-coated gold nanoclusters for fluorescent detection of bisphenol A. Sens. Actuators B Chem. 2015, 211, 507-514. [CrossRef]

237. Wu, Y.-T.; Liu, Y.-J.; Gao, X.; Gao, K.-C.; Xia, H.; Luo, M.-F.; Wang, X.-J.; Ye, L.; Shi, Y.; Lu, B. Monitoring bisphenol A and its biodegradation in water using a fluorescent molecularly imprinted chemosensor. Chemosphere 2015, 119, 515-523. [CrossRef] 
238. Ren, X.; Chen, L. Quantum dots coated with molecularly imprinted polymer as fluorescence probe for detection of cyphenothrin. Biosens. Bioelectron. 2015, 64, 182-188. [CrossRef]

239. Liu, G.; Chen, Z.; Jiang, X.; Feng, D.-Q.; Zhao, J.; Fan, D.; Wang, W. In-situ hydrothermal synthesis of molecularly imprinted polymers coated carbon dots for fluorescent detection of bisphenol A. Sens. Actuators B Chem. 2016, 228, 302-307. [CrossRef]

240. Ensafi, A.A.; Zakery, M.; Rezaei, B. An optical sensor with specific binding sites for the detection of thioridazine hydrochloride based on ZnO-QDs coated with molecularly imprinted polymer. Spectrochim. Acta Part A Mol. Biomol. Spectrosc. 2018, 206, 460-465. [CrossRef]

241. Fang, M.; Zhou, L.; Zhang, H.; Liu, L.; Gong, Z.-Y. A molecularly imprinted polymers/carbon dots-grafted paper sensor for 3-monochloropropane-1,2-diol determination. Food Chem. 2018, 274, 156-161. [CrossRef]

242. Feng, J.; Tao, Y.; Shen, X.; Jin, H.; Zhou, T.; Zhou, Y.; Hu, L.; Luo, D.; Mei, S.; Lee, Y.-I. Highly sensitive and selective fluorescent sensor for tetrabromobisphenol-A in electronic waste samples using molecularly imprinted polymer coated quantum dots. Microchem. J. 2018, 144, 93-101. [CrossRef]

243. Mehrzad-Samarin, M.; Faridbod, F.; Ganjali, M.R. A luminescence nanosensor for Ornidazole detection using graphene quantum dots entrapped in silica molecular imprinted polymer. Spectrochim. Acta Part A Mol. Biomol. Spectrosc. 2018, 206, 430-436. [CrossRef] [PubMed]

244. Ahmadpour, H.; Hosseini, S.M.M. A solid-phase luminescence sensor based on molecularly imprinted polymer-CdSeS/ZnS quantum dots for selective extraction and detection of sulfasalazine in biological samples. Talanta 2018, 194, 534-541. [CrossRef] [PubMed]

245. Shirani, M.P.; Rezaei, B.; Ensafi, A.A. A novel optical sensor based on carbon dots embedded molecularly imprinted silica for selective acetamiprid detection. Spectrochim. Acta Part. A Mol. Biomol. Spectrosc. 2018, 210, 36-43. [CrossRef]

246. Zheng, L.; Zheng, Y.; Liu, Y.; Long, S.; Du, L.; Liang, J.; Huang, C.; Swihart, M.; Tan, K. Core-shell quantum dots coated with molecularly imprinted polymer for selective photoluminescence sensing of perfluorooctanoic acid. Talanta 2018, 194, 1-6. [CrossRef]

247. Dai, J.; Dong, X.; de Cortalezzi, M.F. Molecularly imprinted polymers labeled with amino-functionalized carbon dots for fluorescent determination of 2,4-dinitrotoluene. Microchim. Acta 2017, 184, 1369-1377. [CrossRef]

248. Dai, J.; de Cortalezzi, M.F. Influence of $\mathrm{pH}$, ionic strength and natural organic matter concentration on a MIP-Fluorescent sensor for the quantification of DNT in water. Heliyon 2019, 5, e01922. [CrossRef] [PubMed]

249. Sa-Nguanprang, S.; Phuruangrat, A.; Bunkoed, O. An optosensor based on a hybrid sensing probe of mesoporous carbon and quantum dots embedded in imprinted polymer for ultrasensitive detection of thiamphenicol in milk. Spectrochim. Acta Part A Mol. Biomol. Spectrosc. 2021, 264, 120324. [CrossRef]

250. Cui, Y.; Su, A.; Feng, J.; Dong, W.; Li, J.; Wang, H.; Ni, X.; Jiang, Y. Development of silica molecularly imprinted polymer on carbon dots as a fluorescence probe for selective and sensitive determination of cetirizine in saliva and urine. Spectrochim. Acta Part A Mol. Biomol. Spectrosc. 2021, 264, 120293. [CrossRef] [PubMed]

251. Liu, W.; Guo, Y.; Luo, J.; Kou, J.; Zheng, H.; Li, B.; Zhang, Z. A molecularly imprinted polymer based a lab-on-paper chemiluminescence device for the detection of dichlorvos. Spectrochim. Acta Part A Mol. Biomol. Spectrosc. 2015, 141, 51-57. [CrossRef] [PubMed]

252. Duan, H.; Li, L.; Wang, X.; Wang, Y.; Li, J.; Luo, C. A sensitive and selective chemiluminescence sensor for the determination of dopamine based on silanized magnetic graphene oxide-molecularly imprinted polymer. Spectrochim. Acta Part A Mol. Biomol. Spectrosc. 2015, 139, 374-379. [CrossRef]

253. Qiu, H.; Fan, L.; Li, X.; Li, L.; Sun, M.; Luo, C. A microflow chemiluminescence sensor for indirect determination of dibutyl phthalate by hydrolyzing based on biological recognition materials. J. Pharm. Biomed. Anal. 2013, 75, 123-129. [CrossRef]

254. Yang, Y.; Fang, G.; Wang, X.; Zhang, F.; Liu, J.; Zheng, W.; Wang, S. Electrochemiluminescent graphene quantum dots enhanced by MoS2 as sensing platform: A novel molecularly imprinted electrochemiluminescence sensor for 2-methyl-4-chlorophenoxyacetic acid assay. Electrochim. Acta 2017, 228, 107-113. [CrossRef]

255. Yang, Y.; Fang, G.; Wang, X.; Liu, G.; Wang, S. Imprinting of molecular recognition sites combined with $\pi$-donor-acceptor interactions using bis-aniline-crosslinked $\mathrm{Au}-\mathrm{CdSe} / \mathrm{ZnS}$ nanoparticles array on electrodes: Development of electrochemiluminescence sensor for the ultrasensitive and selective detection of 2-methyl-4-chlorophenoxyacetic acid. Biosens. Bioelectron. 2015, 77, 1134-1143. [CrossRef]

256. Wang, S.; Ge, L.; Li, L.; Yan, M.; Ge, S.; Yu, J. Molecularly imprinted polymer grafted paper-based multi-disk micro-disk plate for chemiluminescence detection of pesticide. Biosens. Bioelectron. 2013, 50, 262-268. [CrossRef]

257. Duan, H.; Li, L.; Wang, X.; Wang, Y.; Li, J.; Luo, C. CdTe quantum dots@luminol as signal amplification system for chrysoidine with chemiluminescence-chitosan/graphene oxide-magnetite-molecularly imprinting sensor. Spectrochim. Acta Part A Mol. Biomol. Spectrosc. 2016, 153, 535-541. [CrossRef]

258. Jiang, Q.; Zhang, D.; Cao, Y.; Gan, N. An antibody-free and signal-on type electrochemiluminescence sensor for diethylstilbestrol detection based on magnetic molecularly imprinted polymers-quantum dots labeled aptamer conjugated probes. J. Electroanal. Chem. 2017, 789, 1-8. [CrossRef]

259. Hu, L.; Zhou, T.; Feng, J.; Jin, H.; Tao, Y.; Luo, D.; Mei, S.; Lee, Y.-I. A rapid and sensitive molecularly imprinted electrochemiluminescence sensor for Azithromycin determination in biological samples. J. Electroanal. Chem. 2018, 813, 1-8. [CrossRef] 
260. Wang, D.; Jiang, S.; Liang, Y.; Wang, X.; Zhuang, X.; Tian, C.; Luan, F.; Chen, L. Selective detection of enrofloxacin in biological and environmental samples using a molecularly imprinted electrochemiluminescence sensor based on functionalized copper nanoclusters. Talanta 2021, 236, 122835. [CrossRef]

261. Cennamo, N.; D'Agostino, G.; Pesavento, M.; Zeni, L. High selectivity and sensitivity sensor based on MIP and SPR in tapered plastic optical fibers for the detection of l-nicotine. Sens. Actuators B Chem. 2014, 191, 529-536. [CrossRef]

262. Cennamo, N.; De Maria, L.; D’Agostino, G.; Zeni, L.; Pesavento, M. Monitoring of Low Levels of Furfural in Power Transformer Oil with a Sensor System Based on a POF-MIP Platform. Sensors 2015, 15, 8499-8511. [CrossRef] [PubMed]

263. Shrivastav, A.M.; Mishra, S.K.; Gupta, B.D. Surface Plasmon Resonance-Based Fiber Optic Sensor for the Detection of Ascorbic Acid Utilizing Molecularly Imprinted Polyaniline Film. Plasmonics 2015, 10, 1853-1861. [CrossRef]

264. Shrivastav, A.; Usha, S.P.; Gupta, B.D. Fiber optic profenofos sensor based on surface plasmon resonance technique and molecular imprinting. Biosens. Bioelectron. 2015, 79, 150-157. [CrossRef]

265. Ayankojo, A.G.; Reut, J.; Öpik, A.; Furchner, A.; Syritski, V. Hybrid molecularly imprinted polymer for amoxicillin detection. Biosens. Bioelectron. 2018, 118, 102-107. [CrossRef]

266. Jiang, S.; Peng, Y.; Ning, B.; Bai, J.; Liu, Y.; Zhang, N.; Gao, Z. Surface plasmon resonance sensor based on molecularly imprinted polymer film for detection of histamine. Sens. Actuators B Chem. 2015, 221, 15-21. [CrossRef]

267. Rahtuvanoğlu, A.; Akgönüllü, S.; Karacan, S.; Denizli, A. Biomimetic Nanoparticles Based Surface Plasmon Resonance Biosensors for Histamine Detection in Foods. Chem. Select 2020, 5, 5683-5692. [CrossRef]

268. Sun, T.; Zhang, Y.; Zhao, F.; Xia, N.; Liu, L. Self-assembled biotin-phenylalanine nanoparticles for the signal amplification of surface plasmon resonance biosensors. Microchim. Acta 2020, 187, 1-7. [CrossRef]

269. Çakır, O.; Baysal, Z. Pesticide analysis with molecularly imprinted nanofilms using surface plasmon resonance sensor and LC-MS/MS: Comparative study for environmental water samples. Sens. Actuators B Chem. 2019, 297, 126764. [CrossRef]

270. Akgönüllü, S.; Yavuz, H.; Denizli, A. SPR nanosensor based on molecularly imprinted polymer film with gold nanoparticles for sensitive detection of aflatoxin B1. Talanta 2020, 219, 121219. [CrossRef] [PubMed]

271. Özgür, E.; Topçu, A.A.; Yılmaz, E.; Denizli, A. Surface plasmon resonance based biomimetic sensor for urinary tract infections. Talanta 2020, 212, 120778. [CrossRef] [PubMed]

272. Kamra, T.; Zhou, T.; Montelius, L.; Schnadt, J.; Ye, L. Implementation of Molecularly Imprinted Polymer Beads for Surface Enhanced Raman Detection. Anal. Chem. 2015, 87, 5056-5061. [CrossRef] [PubMed]

273. Kamra, T.; Xu, C.; Montelius, L.; Schnadt, J.; Wijesundera, S.A.; Yan, M.; Ye, L. Photoconjugation of Molecularly Imprinted Polymer Nanoparticles for Surface-Enhanced Raman Detection of Propranolol. ACS Appl. Mater. Interfaces 2015, 7, 27479-27485. [CrossRef] [PubMed]

274. Hu, Y.; Feng, S.; Gao, F.; Li-Chan, E.C.; Grant, E.; Lu, X. Detection of melamine in milk using molecularly imprinted polymerssurface enhanced Raman spectroscopy. Food Chem. 2015, 176, 123-129. [CrossRef] [PubMed]

275. Chen, S.N.; Li, X.; Han, S.; Liu, J.H.; Zhao, Y.Y. Synthesis of surface-imprinted Ag nanoplates for detecting organic pollutants in water environments based on surface enhanced Raman scattering. RSC Adv. 2015, 5, 99914-99919. [CrossRef]

276. Guo, Y.; Kang, L.; Chen, S.; Li, X. High performance surface-enhanced Raman scattering from molecular imprinting polymer capsulated silver spheres. Phys. Chem. Chem. Phys. 2015, 17, 21343-21347. [CrossRef]

277. Chang, L.; Ding, Y.; Li, X. Surface molecular imprinting onto silver microspheres for surface enhanc24 June 2013 ed Raman scattering applications. Biosens. Bioelectron. 2013, 50, 106-110. [CrossRef]

278. Ye, J.; Chen, Y.; Liu, Z. A Boronate Affinity Sandwich Assay: An Appealing Alternative to Immunoassays for the Determination of Glycoproteins. Angew. Chem. Int. Ed. 2014, 53, 10386-10389. [CrossRef]

279. Xue, J.-Q.; Li, D.-W.; Qu, L.; Long, Y. Surface-imprinted core-shell Au nanoparticles for selective detection of bisphenol A based on surface-enhanced Raman scattering. Anal. Chim. Acta 2013, 777, 57-62. [CrossRef]

280. Guo, Z.; Chen, L.; Lv, H.; Yu, Z.; Zhao, B. Magnetic imprinted surface enhanced Raman scattering (MI-SERS) based ultrasensitive detection of ciprofloxacin from a mixed sample. Anal. Methods 2013, 6, 1627-1632. [CrossRef]

281. Yin, W.; Wu, L.; Ding, F.; Li, Q.; Wang, P.; Li, J.; Lu, Z.; Han, H. Surface-imprinted $\mathrm{SiO}_{2} @ \mathrm{Ag}$ nanoparticles for the selective detection of BPA using surface enhanced Raman scattering. Sens. Actuators B Chem. 2017, 258, 566-573. [CrossRef]

282. Ren, X.; Li, X. Flower-like Ag coated with molecularly imprinted polymers as a surface-enhanced Raman scattering substrate for the sensitive and selective detection of glibenclamide. Anal. Methods 2020, 12, 2858-2864. [CrossRef]

283. Li, H.; Wang, Y.; Li, Y.; Qiao, Y.; Liu, L.; Wang, Q.; Che, G. High-sensitive molecularly imprinted sensor with multilayer nanocomposite for 2,6-dichlorophenol detection based on surface-enhanced Raman scattering. Spectrochim. Acta Part A Mol. Biomol. Spectrosc. 2019, 228, 117784. [CrossRef]

284. Zhou, J.; Sheth, S.; Zhou, H.; Song, Q. Highly selective detection of 1-Phenylalanine by molecularly imprinted polymers coated Au nanoparticles via surface-enhanced Raman scattering. Talanta 2020, 211, 120745. [CrossRef]

285. Hsu, C.-Y.; Lee, M.-H.; Thomas, J.L.; Shih, C.-P.; Hung, T.-L.; Whang, T.-J.; Lin, H.-Y. Optical sensing of phenylalanine in urine via extraction with magnetic molecularly imprinted poly(ethylene-co-vinyl alcohol) nanoparticles. Nanotechnology 2015, $26,305502$. [CrossRef] [PubMed]

286. Sun, G.; Wang, P.; Ge, S.; Ge, L.; Yu, J.; Yan, M. Photoelectrochemical sensor for pentachlorophenol on microfluidic paper-based analytical device based on the molecular imprinting technique. Biosens. Bioelectron. 2014, 56, 97-103. [CrossRef] [PubMed] 
287. Fang, T.; Yang, X.; Zhang, L.; Gong, J. Ultrasensitive photoelectrochemical determination of chromium(VI) in water samples by ion-imprinted/formate anion-incorporated graphitic carbon nitride nanostructured hybrid. J. Hazard. Mater. 2016, 312, 106-113. [CrossRef] [PubMed]

288. Wang, P.; Dai, W.; Ge, L.; Yan, M.; Ge, S.; Yu, J. Visible light photoelectrochemical sensor based on Au nanoparticles and molecularly imprinted poly(o-phenylenediamine)-modified $\mathrm{TiO} 2$ nanotubes for specific and sensitive detection chlorpyrifos. Analyst 2012, 138, 939-945. [CrossRef]

289. Lu, B.; Liu, M.; Shi, H.; Huang, X.; Zhao, G. A Novel Photoelectrochemical Sensor for Bisphenol A with High Sensitivity and Selectivity Based on Surface Molecularly Imprinted Polypyrrole Modified TiO2Nanotubes. Electroanalysis 2013, 25, 771-779. [CrossRef]

290. Sun, X.; Gao, C.; Zhang, L.; Yan, M.; Yu, J.; Ge, S. Photoelectrochemical sensor based on molecularly imprinted film modified hierarchical branched titanium dioxide nanorods for chlorpyrifos detection. Sens. Actuators B Chem. 2017, 251, 1-8. [CrossRef]

291. Gao, C.; Wang, Y.; Yuan, S.; Xue, J.; Cao, B.; Yu, J. Engineering anatase hierarchically cactus-like TiO 2 arrays for photoelectrochemical and visualized sensing platform. Biosens. Bioelectron. 2016, 90, 336-342. [CrossRef] [PubMed]

292. Wang, Y.; Zang, D.; Ge, S.; Ge, L.; Yu, J.; Yan, M. A novel microfluidic origami photoelectrochemical sensor based on CdTe quantum dots modified molecularly imprinted polymer and its highly selective detection of S-fenvalerate. Electrochim. Acta 2013, 107, 147-154. [CrossRef]

293. Liu, M.; Ding, X.; Yang, Q.; Wang, Y.; Zhao, G.; Yang, N. A pM leveled photoelectrochemical sensor for microcystin-LR based on surface molecularly imprinted $\mathrm{TiO}_{2} @ \mathrm{CNTs}$ nanostructure. J. Hazard. Mater. 2017, 331, 309-320. [CrossRef] [PubMed]

294. Dong, R.; Li, J.; Xiong, H.; Lu, W.; Peng, H.; Chen, L. Thermosensitive molecularly imprinted polymers on porous carriers: Preparation, characterization and properties as novel adsorbents for bisphenol A. Talanta 2014, 130, 182-191. [CrossRef]

295. Li, X.; Wang, X.; Fang, T.; Zhang, L.; Gong, J. Disposable photoelectrochemical sensing strip for highly sensitive determination of perfluorooctane sulfonyl fluoride on functionalized screen-printed carbon electrode. Talanta 2018, 181, 147-153. [CrossRef]

296. Li, R.; Liu, Y.; Cheng, L.; Yang, C.; Zhang, J. Photoelectrochemical Aptasensing of Kanamycin Using Visible Light-Activated Carbon Nitride and Graphene Oxide Nanocomposites. Anal. Chem. 2014, 86, 9372-9375. [CrossRef]

297. Yang, X.; Li, X.; Zhang, L.; Gong, J. Electrospun template directed molecularly imprinted nanofibers incorporated with BiOI nanoflake arrays as photoactive electrode for photoelectrochemical detection of triphenyl phosphate. Biosens. Bioelectron. 2017, 92, 61-67. [CrossRef]

298. Tran, T.; Li, J.; Feng, H.; Cai, J.; Yuan, L.; Wang, N.; Cai, Q. Molecularly imprinted polymer modified TiO2 nanotube arrays for photoelectrochemical determination of perfluorooctane sulfonate (PFOS). Sens. Actuators B Chem. 2014, 190, 745-751. [CrossRef]

299. Wang, R.; Yan, K.; Wang, F.; Zhang, J. A highly sensitive photoelectrochemical sensor for 4-aminophenol based on CdS-graphene nanocomposites and molecularly imprinted polypyrrole. Electrochim. Acta 2014, 121, 102-108. [CrossRef]

300. Gong, J.; Fang, T.; Peng, D.; Li, A.; Zhang, L. A highly sensitive photoelectrochemical detection of perfluorooctanic acid with molecularly imprined polymer-functionalized nanoarchitectured hybrid of AgI-BiOI composite. Biosens. Bioelectron. 2015, 73, 256-263. [CrossRef] [PubMed]

301. Viter, R.; Kunene, K.; Genys, P.; Jevdokimovs, D.; Erts, D.; Sutka, A.; Bisetty, K.; Viksna, A.; Ramanaviciene, A.; Ramanavicius, A. Photoelectrochemical Bisphenol S Sensor Based on ZnO-Nanoroads Modified by Molecularly Imprinted Polypyrrole. Macromol. Chem. Phys. 2019, 221, 1900232. [CrossRef]

302. Whitcombe, M.J.; Chianella, I.; Larcombe, L.; Piletsky, S.A.; Noble, J.; Porter, R.; Horgan, A. The rational development of molecularly imprinted polymer-based sensors for protein detection. Chem. Soc. Rev. 2010, 40, 1547-1571. [CrossRef] [PubMed]

303. Lowdon, J.W.; Diliën, H.; Singla, P.; Peeters, M.; Cleij, T.J.; van Grinsven, B.; Eersels, K. MIPs for commercial application in low-cost sensors and assays-An overview of the current status quo. Sens. Actuators B Chem. 2020, 325, 128973. [CrossRef] 